\title{
AGRICULTURAL \\ PROGRESS IN WESTERN INDIA
}

G. KEATINGE, C.I.E.

LONGMANS, GREEN AND CO. 39 PATERNOSTER ROW, LONDON, E.C.4. FOURTH AVENUE AND 30TH STREET, NEW YORK FOMBAV, CALCUTYA ARD MADRAS 

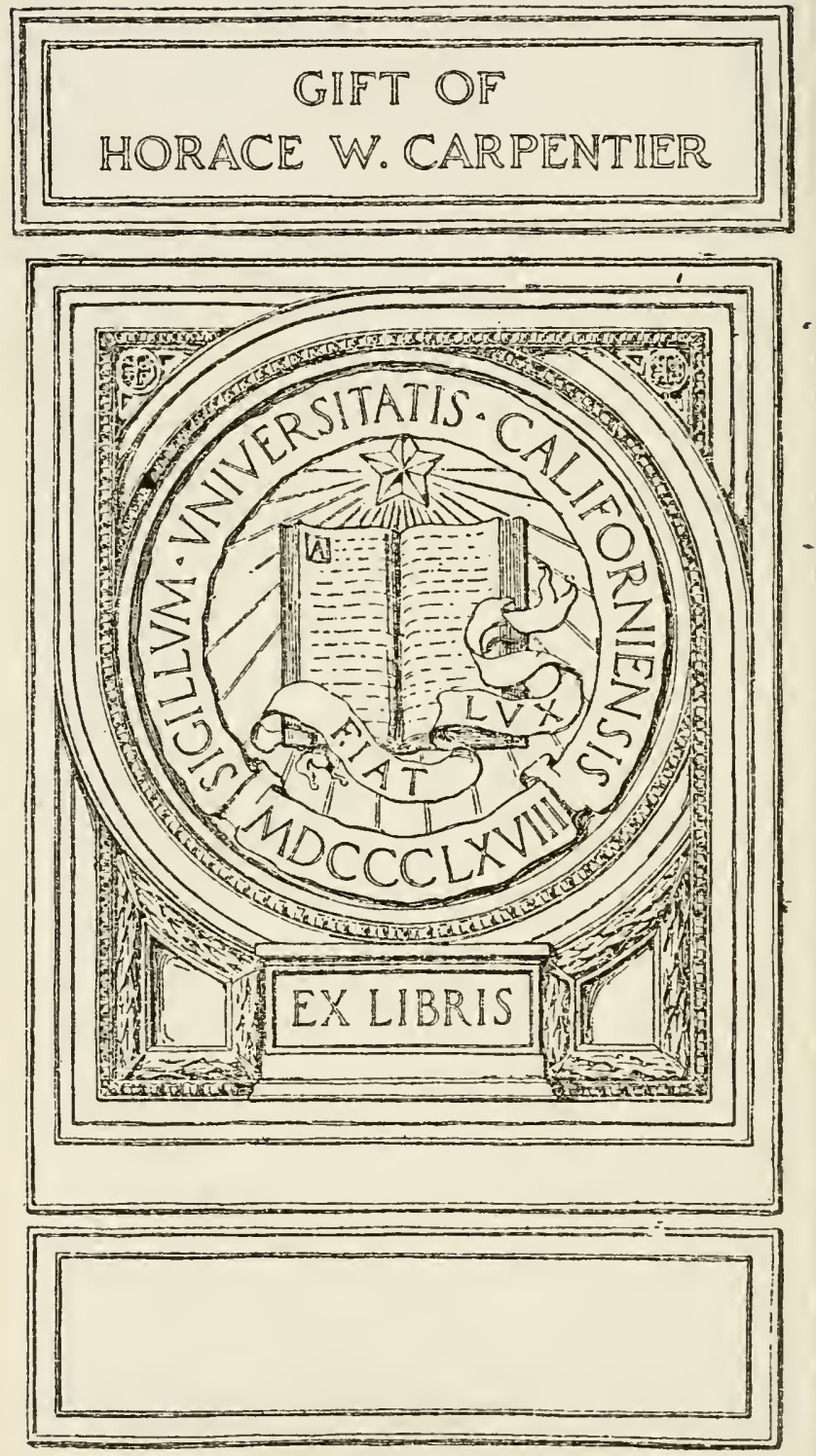

Digitized by the Internet Archive in 2008 with funding from Microsoft Corporation 
AGRICULTURAL PROGRESS

IN

WESTERN INDIA 
BY THE SAME AUTHOR.

\section{RURAL ECONOMY IN THE}

\section{BOMBAY DECCAN.}

With Map and Four Charts. Crown 8vo.

LONGMANS, GREEN AND CO.,

London, New York, Bombay, Calcutta, and Madras. 


\section{AGRICULTURAL PROGRESS}

IN

\section{WESTERN INDIA}
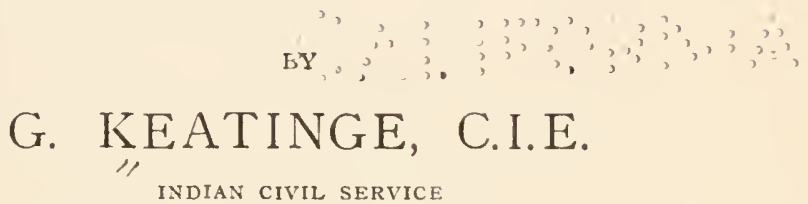

INDIAN CIVIL SERVICE

DIRECTOR OF AGRICULTURE, BOMBAY PRESIDENCY, IgO7 TO I9II

AUTHOR OF "RURAL ECONOMY IN THE BOMBAY DECCAN"

WITH DIAGRAMS

LONGMANS, GREEN AND CO.

39 PATERNOSTER ROW, LONDON FOURTH AVENUE \& 30TH STREET, NEW YORK

BOMBAY, CALCUTTA, AND MADRAS 


$$
S^{x} y^{x^{2}}
$$

Exoontine 
TO THE LAND-HOLDERS AND CULTIVATORS

OF THE BOMBAY PRESIDENCY

FROM WHOM I HAVE EXPERIENCED SO MUCH KINDNESS

DURING THE PAST TWENTY-SEVEN YEARS

"Happy the man, whose wish and care

A few paternal acres bound,

Content to breathe his native air

In his own ground." 



\section{PREFACE.}

Ten years ago I published a book, entitled "Rural Economy in the Bombay Deccan," in which I attempted to give an account of the agricultural facts of the Bombay Deccan. The object of the present book is to estimate the progress that is being made in agriculture in the Bombay Presidency, to analyse the causes of agricultural progress in India and other countries, and the conditions in which it takes place. The obstacles to such progress are also indicated, and the outlines of a general agricultural policy are suggested. If the facts of the situation are not always made clear in this book, a reference to the previous book will probably give the information required. This book is written with reference to the Bombay Presidency, but the facts and arguments stated apply very largely to the other ryotwari tracts of India, and have a bearing on the agricultural problems of any country where small holdings exist or are aimed at.

G. KEATINGE.

Teffont Ewyas,

Salisbury, June, 1921. 



\section{TABLE OF CONTENTS.}

PAGE

Preface . . . . . . . . . . . . . . vii

\section{CHAPTER 1.}

The Criterion of Agricultoral Progress

Prosperity and progress. Percentage of profit. Outturn of produce. Trade movements. Provision of food supply. Condition of the peasantry. Land values. Other indications of progress.

\section{CHAPTER II.}

Agricultural Progress in other Countries

Denmark: Economic reforms. The machinery for rural development. Technical progress. Germany: Economic reforms. The machinery for rural development. Technical progress. England: Economic reforms in the seventeenth and eighteenth centuries. United States of America: Technical progress. Hawaii, Formosa and Java: Rapid progress secured by capitalising agriculture.

\section{CHAPTER III.}

Indications of Progress in Western India .

Crop Outturns. Trade movements. Increase in cultivation. Land values and rentals. Prices. Irrigation. Land improvement. Technique. Spending capacity of the population. Effects of crop failure. Estimate of progress. 
Size and shape of holdings. Subdivision of holdings. Fragmentation of holdings. Permanence of holdings. Action taken elsewhere to improve holdings. Action proposed for the Bombay Presidency. Landlords and tenants. Necessity for irrigation. Reason for slow progress in the construction of irrigation works. Engineering success and financial failure. Scheme proposed.

\section{CHAPTER V.}

Technique. . . . . . . . . .

Cultivation. Manure. Seed. Rotation of Crops. The seasonal factor. Dry-farming. Progress possible. Progress secured.

CHAPTER VI.

EQUIPMENT .

Implemeuts. Fixtures. Live stock. Hindu sentiment with regard to cattle. The cattle industry on an uneconomic basis. Obstructions to scientific breeding and scientific feeding. The situation as regards meat and milk. City milk supply. Dairy farms. Remedial measures attempted.

\section{CHAPTER VII.}

\section{ORganisation}

Business organisation. The organisation of peasant farms. Dependence on a single crop. Distribution of labour throughout the year. Subsidiary industries. The size of the farm governed by bullock power. External organisation. Supply and marketing agencies. The co-operative movement. The marketing of cotton. Insensitive markets. A vicious circle. Agricultural education. 
CHAPTER VIII.

The Human Factor.

The different classes of cultivators. The labour supply. Wages. The peasant proprietor. The intermediate class. Relaxation of effort. Efficiency of labour. The standard of effort. The causes which govern the standard and efficiency of labour. Race. Climate. Institutions. The best cultivators. Potential energy running to waste. The case of Indian emigrant labourers.

\section{CHAPTER IX.}

An Agricultural Policy for Western Indi 168

Recapitulation. The desire for progress. Divergent views of existing facts and future policy. The price of progress. Past policy of the British Government in India. The limitations of its success. The poverty of the Indian peasant. The fundamental obstacles to progress. The steps necessary to remove them. Twelve points of policy. Conclusion.

\section{APPENDIX I.}

The Extent of Subdivision and Fragmentation of Holdings in the Bonbay Presidency . . . . . .

\section{APPENDIX II.}

The Extent of Fragmentation and Subdivision of Holdings in other Countries, the Causes of the Same, and the Remedial Measures Taken . . . . • . 224

\section{APPENDIX III.}

Draft Bill Proposed to Exable Landholders to Correct the Tendency towards Excessive Subdivision and FragMENTATION OF HOLdINGS . . . . . . 



\section{CHAPTER I.}

THE CRITERION OF AGRICULTURAL PROGRESS.

The progress which any country may be making is not, of course, the same thing as its prosperity. The former term denotes the movement that is taking place at the present time, the latter term the state of advancement that has been achieved by past effort. It is true that we often talk of a country as progressive, meaning thereby that it has reached a high state of development; and so far as the unchanging physical conditions of the country are concerned, the fact that progress has been good in the past may lead us to believe that such progress is continuing and will continue. But there are other factors to be considered besides physical conditions; and we know that a country will often make a spurt forward, and then for a period stand still or fall back. When we are comparing the state of a single country at two different periods there is little fear of confusion in this respect, since the essence of the comparison is to show what movement has taken place; but when we are comparing one country with another, the basis of comparison is usually between the general level of advancement 
in each, without reference to the present rate of progress either in the one or the other. Thus while progress and prosperity are closely allied, they must not be confused; for a country which progresses, but at a slower rate than other countries, will fall farther in to the rear in the world's race for national prosperity. It is not difficult to form a general idea of the material prosperity of a country. The ordinary standard of comfort apparent to the casual traveller will give a fair idea of it; and a rough computation of the necessaries and comforts which the average income of the various classes of the people will provide gives a more exact idea. In India, as is well known, the standard of living is low; and in comparing it with the standard of living in England some people have put it as low as 1 to 6 . It is not, however, with the standard of prosperity that this book is primarily concerned, but with the conditions of progress and the rate at which agricultural progress does or might take place. What criterion are we going to take of agricultural progress? Looking at the question from the strictly business point of view, it may fairly be argued that the only criterion of success in farming, as in other enterprises, is to be found in the percentage of profit obtained on capital employed. This criterion would be suitable for a large and wellfinanced estate managed solely for profit, but it is applicable only in a slight degree to the case of small holdings where little capital is employed, and where the object of the cultivator is not so much to get a 
good return on his capital as to support himself and his family by a congenial occupation. In the case of many Indian holdings the great bulk of the capital employed consists of the value of the land; and land values may be, and often are, unduly inflated by the pressure of the population on the soil, and by the fact that there is a keen demand for land as a safe and obvious investment, without much regard to the rate of return that may be expected from it. For our purposes a more valuable estimate of agricultural progress would be based on the outturn of agricultural produce per acre at various periods. Such a criterion is often taken in the case of other countries. It will be stated, for instance, that in the present day, as a result of rapid progress in Denmark, the average gross agricultural produce of land per acre in Denmark is about $£ 8$ as compared with an outturn of $£ 4$ per acre which was obtained fifty years ago in that country, and which is taken as the average outturn of farm land in England at the present day. In a country like Australia, on the other hand, where land is abundant and the population small, extensive cultivation of large areas with a necessarily small outturn per acre may be profitable to individuals, though American observers have questioned whether in such conditions better results, both for the individual and for the State, cannot be obtained by more intensive methods on a smaller area. In western India where the population presses heavily on the cultivable soil, which is all occupied in small holdings, the outturn 
per acre is a matter of great importance, and any steady increase in this outturn would afford strong evidence of agricultural progress. Unfortunately the average produce per acre is a very difficult thing to measure accurately in a country which presents, side by side, farming of such varying degrees of excellence, and where the quantity and distribution of the rainfall is so capricious as to cause from year to year enormous fluctuations of outturn which must largely conceal any average increase in gross production that may be taking place. The figures of particular crop tests or observations spread over a short period are open to the criticism that they are based on particular instances of soil, skill or season, and are not evidence of any general tendency. General statistics of crop outturns for a sufficiently long period ought to give valuable indications, and in countries where the great bulk of the produce is brought to markets in which its amount and value are recorded, such figures do afford useful evidence. In western India trade movements give indications in the case of the export crops, such as cotton and oil seeds; but the staple crops of jowari, bajri, wheat and rice are for the most part consumed locally. To some extent they move, no doubt, but by routes and to local markets which afford no statistics. The Bombay Presidency roughly consumes as much wheat as it grows, and imports large quantities of jowari, bajri and rice for local consumption, while it exports overseas cotton and oilseeds. The average net figures of 
such imports and exports for various decades should give information, but a consideration of such figures will show that the seasonal factor entirely outweighs all others, and makes it impossible to compute any steady and general tendency in crop outturns.

Closely connected with this comes an important consideration of how far a country provides sufficient food for its own population, both in normal times and in abnormal periods of famine or war. The fact that Germany could support 70 to 75 persons per 100 acres of cultivated land, while England, with physical conditions certainly not inferior, could support only 45 to 50 , was of great importance during the recent war; and the dependence of Bombay Presidency for food on Burma and northern India was made unpleasantly evident during the famine of 1918-19.

Then there is another obvious criterion. Has the general condition of the cultivators improved? Probably every one will agree that it is largely on the answer to this question that we must judge the agricultural progress of a country. But by such unanimity the difficulty is only shifted a step further, and few will agree as to whether the condition of the cultivator has improved or not. In discussing this we can only make use of the opinion of competent observers and such statistics as indicate the consumption of articles which tend to the comfort and convenience of the people in general. Land values also will be considered for what they are worth.

So far, the tests mentioned have been those of 
agricultural production on the one side, and the spending capacity of the cultivators on the other. Apart from these we may refer to more technical criteria. There are a number of developments usually found to be associated with progress, and indications are to be looked for in the answers to the following questions :-

1. Has cultivation extended?

2. Has the size and distribution of the holdings become more effective?

3. Has a reasonable supply of capital been attracted to agriculture?

4. Does the cultivator work more or less than he did formerly?

5. Have his efficiency and skill increased?

The general considerations indicated above will be discussed in Chapter III., and the more technical considerations in subsequent chapters; and an effort will be made to distinguish between factors which make agricultural success possible and factors which directly account for increase in agricultural production. 


\section{CHAPTER II.}

AGRICULTURAL PROGRESS IN OTHER COUNTRIES.

IN this chapter it is proposed to consider outstanding examples of agricultural progress achieved in other countries, either as a result of a concerted agricultural policy on the part of the government of the country, or by means of organisation, scientific research and propaganda. Agricultural populations are usually unorganised and inert, and it is only in exceptional circumstances that it is sufficient to clear the road to progress and leave the farmers to seize the opportunity. On the other hand, the economic situation is often such as to block measures that may be taken for the application of scientific methods to agriculture; and in such cases, unless the way is cleared, progress is, of necessity, greatly restricted. It is proposed to consider, in this connection, the cases of Denmark and Germany, where sustained efforts of both kinds were taken with conspicuous success; of England in the eighteenth century, where economic measures in connection with the land were sufficient to liberate forces which led to increased production, without any further direct intervention on the part 
of the government; of the United States of America where general conditions are such that it is claimed that scientific propaganda alone can and does produce enormous results, without any preliminary spade work; and of the tropical countries of Hawaii, Formosa and Java, where agricultural production has been greatly increased by methods which will be described.

* Denmark (population about 3,000,000).-The Napoleonic wars at the end of the eighteenth century had hit Denmark very hard, and the Prussian war of 1864 plunged the country into great distress, besides causing it the loss of much fertile territory. A patriotic movement for the regeneration of the country was then set on foot by individuals and by Societies, organised for various specific purposes; but as late as 1880-90 the rural districts were in a bad way, and the people were leaving the country parts for the towns. During that decade the rate of increase in the total population was 325 per 10,000, while the rural districts showed an increase of only 21 per 10,000. By the period 1901-6 the rural exodus indicated by the above figures had been

* Authorities :-

1. "Report of the Scottish Commission on Agriculture to Denmark, 1904" (Blackwood).

2. "Rural Denmark and its Lessons," by Rider Haggard, 1911.

3. "Rural Denmark and its Schools," by H. W. Foght, 1915 (Macmillan).

4. "Land Settlement in Deumark," by I. G. Stewart, " Jourual of the Ministry of Agriculture," Feb. 1920. 
checked, and for this period of five years the increase in the rural population amounted to 99 per 10,000, indicating improvement in and contentment with rural conditions.

The figures of exports of agricultural produce, mainly butter, bacon and eggs, from Denmark to Great Britain about the same period also indicate the rapid progress that was taking place.

Value of Exports of Agricultural Produce from Denmark to Great Britain.

$\begin{array}{llllll}1899 & \cdot & . & . & . & £ 11,000,000 \\ 1900 & \cdot & . & . & . & £ 12,000,000 \\ 1901 & . & . & . & . & £ 13,000,000 \\ 1902 & . & . & . & . & £ 14,000,000 \\ 1903 & . & . & . & . & £ 16,000,000\end{array}$

At the present time all authorities bear witness to the general well-being and contentment of rural Denmark, and to the high level of education, intelligence and industry to be found there. Now how was this progress obtained? The lines of development were threefold. In the first place fundamental economic reforms calculated to liberate the energies of the people; in the second place measures creating the machinery for development; and in the third place technical advance on scientific lines.

Fundamental Economic Reforms.-Some authorities trace the first economic land reform in Denmark as far back as 1781, when communism in land-holding 
was abandoned. During the nineteenth century the lesson of the necessity for creating and maintaining holdings of a suitable size was learnt. Under the ordinary Danish law of succession each child gets a share in the family property; but by a law of 1837 an exception was made in the case of peasant farms, and the proprietor is allowed to leave the farm intact to any one of his children, subject to a moderate consideration being given to the others, the extent of which is left entirely to the testator. Towards the end of the nineteenth century the tide of public opinion set steadily in favour of small peasant farms as a valuable agency for increasing production and general well-being, and a law was passed to bring into existence a larger number of such farms. Under this law a candidate for a small farm has to satisfy the local Commission that he is sober and industrious, and has a sufficient knowledge of farming, and he has to produce one-tenth of the purchase money. The Commission then finds him a farm of from 3 to 16 acres, advancing nine-tenths of the purchase money for the land and stock. No repayments need be made for the first five years, but after that the holder pays 3 per cent. interest on the money advanced, and 1 per cent. sinking fund for the repayment of the loan. Since 1899 the State has provided $£ 110,000$ to $£ 160,000$ a year to finance such loans. The peasant farms so formed may not be subdivided or mortgaged until the government loan is paid off, nor can distraint 
be levied on the holding or stock; so that for about a century they are protected against some of the worst calamities to which small holdings are subject. So far as the small holders thus created are concerned, it has been estimated by a competent observer that about half of these peasant farmers succeed, about one-third just manage to live, and the remaining one-sixth fail. So far as national wealth is concerned it may be noted that the number of stock kept on these farms, per acre, and the wealth produced, per acre, are far greater than on the larger farms.

Denmark is now essentially a land of small farms. The bulk of the land is divided into farms of from 33 to 270 acres, but the number of holdings between 11 and 33 acres is large, and the number of holdings less than 11 acres very large. "The great majority of the farmers in Denmark now own their own farms, and only 10 per cent. of the farmers are tenants. The rearrangement of holdings in sizes considered to be suitable is only part of a general policy, and is not the end of direct government action for the amelioration of agriculture. The country roads have been improved, and so have the rural postal arrangements and telephone system; while Societies, which have as their objects the reclamation of heath lands, the planting of wind-breaks on the seashore, drainage and irrigation, have been encouraged and subsidised.

The machinery for rural development consists of admirable arrangements for rural and agricultural 
education and co-operation. Both the agricultural schools and the co-operative Societies are private ventures and were started as such, though they now receive government subsidies. Denmark aims at a high level of general education rather than of technical education; but there are a number of excellent agricultural schools which are well attended and at which the pupils pay fees. It is not proposed to give any detailed account of the system of Danish education; but the general keenness for education may be judged by the fact that large numbers of the children of small farmers and peasants voluntarily attend the Popular High Schools between the ages of 17 and 25 to continue their general education.

In the case of co-operative activities, also, the matter has been so frequently and so fully described that it is only necessary to state that an excellent system of rural organisation exists, which embraces such activities as creameries, bacon-curing factories, poultry Societies, live stock Societies of various kinds, bee Societies, and Societies for the purchase and distribution of seed, artificial manures and agricultural implements. These Societies are federated, and the members bind themselves for a period of years to carry out all purchases and sales through the medium of their own Society, and are bound by very strict rules which they loyally carry out. The extreme value of this organisation to the farmers is recognised by all observers; but it is unnecessary to enlarge on the subject here. 
Technical progress on scientific lines is the third line of advance; and in this direction the problem in Denmark is comparatively simple, since in that country agricultural production is very uniform. Denmark depends on the cow for its wealth, and its problems are mainly concerned with the scientific breeding and the scientific feeding of milch cattle. Butter is the main subject of export, and the bacon produced is a subsidiary industry based on the necessity of making a profitable use of the separated milk. Great success in grading up the cows to a high level of milk production has been obtained by the cattle-breeding Societies, and the principles of correct feeding are carried out with much precision. The co-operative Societies concerned with milk control base the feeding rations for cows on a strict relation between the yield of milk and the food consumed, with a view to eliminate unprofitable animals. Every cow is visited once a fortnight, not by a Government Inspector but by an inspector of a milk control Society. These inspectors are usually women who have received their technical training at the State Agricultural College. They test the milk, determine the exact proportion of food that each cow should receive, and, in case of sickness amongst the cattle, prescribe remedies. In cases of doubt or difficulty, not only in matters connected with cattle, but also in connection with cropping, manuring, etc., the farmers depend very largely on their advice ; and the immense value of such an agency for propaganda purposes may well be imagined. In 


\section{PROGRESS IN OTHER COUNTRIES}

all co-operative activity self-help is the watchword, but government gives its warm support to the movement and aids it by subsidies. It may be of interest to state that the agricultural budget of Denmark for 1904 was roughly $£ 80,000$ of which about half was expended by the State on its direct agricultural activities, iconsisting of the maintenance of the Central Agricultural and Veterinary College, research and propaganda work; while the remaining $£ 40,000$ was divided about equally between subsidies for agricultural education and subsidies for the reclamation of waste lands, stock improvements, milk control, etc.

In the matter of cultivation which is devoted mainly to the production of food for the live stock, the improvement which has taken place is due chiefly to the increased amount of manure which the larger number of stock now kept provide, and to the fact that the farm-yard manure is very carefully preserved and applied to the fields.

By such measures rural Denmark has been rescued during the past half century from a condition of acute depression, poverty and backwardness, and placed in a very high position amongst the nations of the world in the matter of rural progress and contentment. In effecting this remarkable change it must be noted that a very important factor has been the thrifty, hardworking, honest and law-abiding character of the people, and the fact that agriculture is recognised as being everything to Denmark. In that country other industries compete little or nothing with agriculture, 
and the government policy is little but a policy of stimulating agriculture, and is conducted by ministers largely drawn from the farming classes, many of whom have been small farmers themselves.

* Germany. - The very striking improvement in German agriculture which took place during the thirty years from 1883 to 1913 is comparable with that of Denmark, though it is of a more varied nature and took place on somewhat different lines. In 1883 agricultural production in Germany was distinctly backward, and the produce of crops, per acre, compared very unfavourably with that of England. During the thirty years in question, the total production of the country of cereals and potatoes was more than doubled, and though part of this increase was due to the fact that more land was brought under the plough, still the nature of the progress may be judged by the large increase of produce, per acre, which has taken place during this period. This amounts to about 70 per cent. in the case of both cereals and potatoes. It might have been thought that the increase in the area of cultivation would have been accomplished with corresponding loss of live stock, due to diminishing grazing grounds. 'That this has not taken place the statistics show, for there has been a 25 per cent. increase in horses and cattle. It is true that a marked change has taken place in the substitution of pigs for sheep. During the thirty years in question Germany

* "The recent development of German Agriculture," by T. H. Middleton, published by Ministry of Agriculture, London, 1917. 
increased its number of pigs by $12,000,000$ with an equal diminution in the number of its sheep, and this fact is, no doubt, connected with the restricted area of grazing grounds; but in the production of meat and milk, per acre of farm land, Germany is well ahead of England, though in the former country the percentage of farm land devoted to fodder production is only 32, whereas in the latter it is 69 .

The progress of German agriculture is enthusiastically proclaimed in Germany, and it is admitted by competent observers of other countries. Further evidence of the reality of this progress is afforded by the relatively high number of men and women, per acre, employed in agriculture, the enhancement in the wages of farm labourers, and the large increase that has taken place both in the sale price and in the rentals of farm lands. In considering the causes of this remarkable agricultural progress we may again classify the factors into three main groups.

The fundamental economic measures taken to promote prosperity in agriculture were prompted by an appreciation in Germany of the political and social value of a strong and prosperous peasantry, and a desire to secure the national food supply. They consisted of a series of measures to create and to maintain a suitable division of the land into farms of a convenient size. These measures are described in detail elsewhere.* As a result, 70 per cent. of the farm land 
is now divided into farms of less than 100 acres each, the two largest classes being :-

$$
\begin{aligned}
& 12 \frac{1}{2} \text { to } 50 \text { acres } . \quad . \quad . \quad . \quad 32 \cdot 7 \text { per cent. } \\
& 50,100, \quad . \quad . \quad . \quad 214 \text { per cent. }
\end{aligned}
$$

and about 93 per cent. of the farmers in Germany own the land that they cultivate. The policy of tariff protection was put forward in the first place by the agrarian party, and was subsequently adopted by a party whose view was that "Germany must keep under the protection of her guns, the ground upon which her corn grows and her cattle graze". In other words that she must produce her own food and not be too dependent on imports from abroad. This view was adopted by the State, and the tariff protection afforded to agriculture, though not very substantial in hard cash, was successful in restoring confidence to the farmers and emboldening them to resort to intensive cultivation.

Amongst the general economic causes from which German agriculture has profited must be mentioned the stimulating influence of an increase in the general prosperity of the nation. Industrial competition no doubt caused a scarcity of agricultural labour. This, however, stimulated the use of machinery. Further, it was the prosperity of the towns that gave agriculture good prices for its produce, furnished cheap capital, provided the agriculturist with guidance in co-operative methods, and in general infected him with the 


\section{PROGRESS IN OTHER COUNTRIES}

enterprise which characterised German industries of this period.

The machinery for agricultural development is supplied by co-operation, education, and by efficient arrangements for the supply of credit to farmers.

Credit.-The chief agencies for the supply of credit are the Land Mortgage Credit Associations which lend to the larger farmers, and the Local Savings Banks which lend to the small ones. These organisations make careful inquiries as to the skill and honesty of a farmer before they advance a loan, and unless a farmer has a good reputation in these matters, he receives but little credit. In this way a continuous process of selection is in operation under which the fittest men amongst the agriculturists survive.

Co-operation.-The chief activities of agricultural co-operation are conducted by the Societies for the supply of concentrated manures and feeding stuffs, co-operative creameries, implement Societies and potato-drying Societies. Their work is very extensive and their value to the farmer great; but it is not proposed to go into any details regarding the wellknown facts of the situation.

Education.-Efficient agricultural education is given at the colleges, and many of the larger landowners receive such an education, while the other pupils readily find posts as estate managers or in the Agricultural Department. Five universities and three technical colleges in Prussia alone receive government 
subsidies on account of agricultural education. Seventeen permanent agricultural schools are maintained, and a large number of winter courses in agriculture are given, a feature of the latter being that during the following summer the teachers visit their pupils and give them technical advice on their own farms. Many other courses also are given in subjects related to agriculture. The German policy was to concentrate first on research and higher education, and this policy has been very successful. It is also worth noting that it is usual for the sons of the larger land-owners to receive a technical education in agriculture, and that it is largely from their well-managed estates that improvements have spread amongst the peasant cultivators of the country.

Technical Progress on Scientific Lines.-It is claimed by the Germans, and with much truth, that the progress in agriculture achieved in Germany during the past quarter of a century is the result of the union of practice with science. The chief technical improvements may be summed up as follows: the soil has been better cultivated, crops have been more skilfully manured, plants and animals have been improved in type, the use of oilcakes and other feeding stuffs has increased, and sanitary laws have led to a great improvement in the health of live stock. It would be out of place here to enlarge on the details of this progress, but it may be mentioned that between 1890 and 1910 the use of artificial fertilisers in Germany increased fourfold. 
One other point in connection with agricultural progress in Germany must be mentioned, and this is the progress of the sugar beet industry. The area under sugar beet in Germany before the war was about 1,500,000 acres, or less than 2 per cent. of the total cultivated land. Even in the districts where it is most cultivated it does not occupy more than 10 per cent. of the cultivated land. Judged by the extent of cultivation, therefore, it might be deemed to be unimportant ; but from other points of view its importance is emphasised by all impartial observers. In the first place, it produces the greatest amount of human food, yielding five times as much as rye, the most prolific cereal, and twice as much as potatoes from the same area of land; while the residues of sugar-making are extensively used in animal feeding, with the result that animal husbandry has flourished wherever sugar beet is grown. Further, it necessitates deep cultivation and heavy manuring, with most beneficial results to succeeding crops. As regards labour, it employs a large number of hands in producing the crop, and the factory work gives considerable employment during the winter when the demand for field labour falls off. Last, but not least, it exercises a very beneficial educative effect on all branches of the surrounding agricultural industry. This is due not only to the intensive and intelligent cultivation necessary to the successful production of beets, but also to the knowledge of scientific possibilities and processes which has been brought to the atten- 
tion of the farmers by the scientific grading up of the sugar contents of the beet and the skilful handling of the crop in the factory. In 1875 it took $11 \frac{1}{2}$ tons of beet to produce 1 ton of raw sugar. In 1910, as a result of continuous selection, it took only 6 tons. The great national benefits that could be derived from the cultivation of this crop were long ago recognised in Germany, and the German Government exerted itself to encourage beet cultivation by means of tariff protection and direct bounties which were carefully regulated so as to encourage high-class production rather than to bolster up inefficient methods. In this way a powerful industry has been established, profitable alike to the community and to the Government. In 1910 the amount of excise duty on sugar paid by the sugar factories amounted to no less than $£ 10,000,000$, and formed an important source of State revenue. To the agricultural community the value of beet growing is roughly indicated by the fact that in the beet-growing districts the rents and value of land, per acre, are from two to three times higher than they are in the districts where beet is little grown.

In a less degree the potato crop has had a similar influence on German agriculture. Of the total crop of $45,000,000$ tons that is raised, it is estimated that only 12,000,000 tons are usually consumed as human food, 17,000,000 tons are fed to stock, and 4,000,000 tcns are converted into spirit and starch. Like beet, the crop is an intensive one and produces a large 


\section{PROGRESS IN OTHER COUNTRIES}

quantity of food per acre, and is the basis of the rural manufactures of spirit and starch and of the farm industry of potato drying. These industries find employment during the off season for farm labour, and the portion of the crop usually devoted to manufacture affords a useful reserve of food against emergencies.

It must be added that the attitude of the farmer towards agricultural progress has done much to facilitate the movement; for the leaders amongst German agriculturists regard the cultivation of the land, in the best possible way, as being a duty which is owing to the Fatherland.

* England. - It is now proposed to consider the case of England during the seventeen th and eighteenth centuries, as an example of how progress was effected in agriculture with a minimum of government action or interference, progress which must be considered as very remarkable and rapid with reference to the period in question and the relatively small facilities for development which then existed. In this case there was no question of setting up any elaborate machinery for the provision of credit, education, research or co-operative action. Certain grave defects in English farming had been the subject of constant comment as far back as the sixteenth century; the technical remedies were fairly well understood, and there were men with the requisite skill and

* "English Farming Past and Present," by R. E. Prothero (Longmans, 1912). 
capital ready to apply them. Certain fundamental economic difficulties, however, stood in the way, and it is proposed to consider how they were removed, and with what results.

Prior to the seventeenth century the traditional system of farming in England was what was known as the "open-field" system. The land of a village was usually divided into three fields, one of which was under cereals, one under beans and peas and the third fallow. In each of these fields the farmers were assigned plots, according to their rights, consisting of strips of land. In order to divide equally the good and bad, the well and ill situated fields, the strips allotted to each man did not lie together, but were intermixed and scattered. The cultivated area was for part of the year fenced off from the rest, but after harvest the temporary fence was removed and the village cattle allowed to graze over the whole. Sometimes plots of meadow were allotted by ballot or otherwise to individuals for temporary use for hay cutting; but the greater part of the live stock picked up a precarious living on the common grazing grounds and on the weedy stubbles from which the crop had been removed. Under the communal system no regular development of the land was possible, nor could improvement in the breeding or feeding of live stock take place. As early as the reign of Elizabeth writers enlarge on the superior yield of enclosed land and the obstacles to successful farming presented by the open-field system, the perpetual disputes, the 


\section{PROGRESS IN OTHER COUNTRIES}

damage to crops, the difficulty of good cultivation and the cost of keeping herdsmen. As early as the sixteenth century enclosures of land did begin on a limited scale, either by the consent of the parties interested or as a result of the sale of rights, and sometimes even by force or fraud; but the extent of land enclosed was small. This tendency to enclosure continued throughout the seventeenth century, and wherever it took place the improvement which resulted was the subject of comment, and the writers of this period are very decided in their advocacy of land enclosure, enumerating amongst other reasons the liability of the cattle grazed on the common land to diseases of all kinds, and to starvation in the winter. They also referred to the way in which the ownership of a small plot of land, together with common grazing rights, disposed the smaller cultivators to a life of idleness and thriftlessness, without offering them the possibility of adequate subsistence. The stock reared on the commons are described as dwarfed and miserable, and the state of the commons as disgracefully bad. It is also noted that no winter crops could be grown so long as the open fields were subject to common rights of pasturage from August to February.

By the eighteenth century the great benefits of enclosure were generally admitted, and no voice was raised against the movement on any other ground than the moral and social evil inflicted on the openfield farmers and commoners who were ejected. The 
process of enclosure consisted of the consolidation of the intermixed strips of open-field farms, and of dividing the commons attached to them, as adjuncts of the arable holdings. Up to the eighteenth century, enclosure was possible only by private agreement, but in that century a large number of Acts of Parliament were passed sanctioning enclosures and appointing commissioners to do the work. The effect of these Acts was to completely change the face of the country. The work went on apace through the eighteenth century and was practically complete at an early period of the nineteenth century. As a result of these operations the land was thrown into the hands of large landlords, and substantial yeomen, and much capital and intelligence were attracted to its improvement. Fields were fenced and drained, buildings erected and trees planted. The general introduction of root crops, clover and artificial grasses made scientific feeding possible, and immense care was lavished on the breeding of stock of all kinds, which were improved out of all recognition. The existence of cheap iron and steel, also, permitted great improvements in all kinds of agricultural implements. In all such matters the larger land-owners took the lead. Agricultural development became the fashion with all from the King downwards, and the small farmers followed suit. It is recorded that Coke of Norfolk showed how ploughing could be done at half the cost with an improved plough, but it took twenty years for any of his neighbours to follow his example. Jethro 


\section{PROGRESS IN OTHER COUNTRIES}

Tull successfully cultivated turnips on his estate in the last decade of the seventeenth century, but the practice did not spread to his neighbours for twenty years, or become common for another fifty years.

It is not possible to approve of all the circumstances which attended this revolution of land tenure in England; but of the enormous agricultural progress that took place as a consequence there can be no doubt. The land was greatly improved, and so were methods of cultivation, breeding and feeding. Agricultural production was greatly stimulated, and the increased produce enabled England to meet the strain of the Napoleonic wars, to bear the burden of additional taxation and to feed the vast centres of commercial industry, which sprang up at a time when food could not have been provided from another country. The penalty that the country paid was the divorce of the peasantry from the soil, and the extinction of the commoners and open-field farmers. There can be no doubt that injustice was frequently inflicted on people who lost their rights, and that this injustice was keenly felt during the periods of low wages and high prices, which subsequently occurred. Some hardship is probably inevitable in introducing reforms of this kind, and, human nature being what it is, it must be recognised that such a movement provides opportunities for injustice and for the oppression of the weak by the strong; but the progress aimed at was secured, and in the matter of agriculture, England rose from a very backward state to a leading 
position amongst the nations of the world. It is not suggested that the present condition of land-holding in India is in all respects similar to the old system which blocked progress so effectually in England, still less is it suggested that identical remedial measures could or should be introduced in India; but the parallel is sufficiently close to be very instructive and to indicate the nature of some of the disabilities from which India suffers.

United States of America.-It is not proposed here to consider the effect of the scientific research conducted by the well-staffed and organised branches of the Federal Department of Agriculture, nor yet the more localised experimental and demonstration work of the Agricultural Departments of the various States, but merely to refer to the results claimed for a particular campaign of agricultural demonstration undertaken with the help of trust funds. The account of this campaign is given in a publication entitled "The General Education Board, 1902-14".* The object of the Board was to improve the educational facilities of the southern States, and after inquiry it was decided that more favourable economic conditions must be obtained before comprehensive school systems could be supported by taxation. It was no use giving the people a school system which they were not prosperous enough to support; so it was decided to make an effort to enlarge the available resources of the

* Published by General Education Board, 61 Broadway, New York, 1916. 
people. In the tract selected it was found that 85 per cent. of the population was rural in character, that the soil, climate and other physical conditions were favourable to rural prosperity, and it was decided that what the farmer suffered from was a lack of knowledge of the principles of scientific agriculture. To cure this, a campaign to inculcate the fundamental principles of scientific agriculture was undertaken by a band of itinerant instructors. The principles to be inculcated were laid down in the form of ten agricultural commandments :-

1. The removal of all surplus water on and in the soil.

2. Deep fall ploughing, with a winter cover crop.

3. The best seed.

4. The proper spacing of plants.

5. Intensive cultivation and systematic rotation.

6. The judicious use of farm-yard manure, legumes and commercial fertilisers.

7. The home production of food required for the family and for the stock.

8. The use of more horse power and better machinery.

9. The raising of more and better stock, including the cultivation of grasses and forage plants.

10. Keeping an accurate account of the cost of farm operations.

The method adopted was to select intelligent farmers and induce them to carry out the practices indicated above, and when these practices had been 
successfully introduced, to use their farms as demonstration farms for the instruction of their neighbours. Apparently this method was very successful, and figures of individual cases are given to show that the farmers selected were enabled to more than double their outturn, and immensely improve their position in a very short time. The reader is asked to judge the general results of the campaign by the fact that the yield per acre of cotton and maize on the demonstration farms was double the average yield for the tract, that many valuable new crops were introduced, and that the selected farmers were induced to clean up their farms, improve their farm equipment all round, build better houses and barns, and establish good pastures. It would be possible in any country to select a few of the best farmers and to show that their outturns were largely in excess of the average, but in this case the number of farms affected was very large, and amounted to some 70,000 farms in five States in the course of ten years. Taking the results claimed at their face value, they are certainly very remarkable, and are instructive chiefly for the reason that they appear to indicate what can be accomplished by scientific propaganda, when the fundamental economic condition of the farmers is essentially sound. In this case the holdings were apparently of a suitable size and distribution, and admitted of a well-ordered development for which the requisite capital was forthcoming; and there is no mention of any crushing load of debt or conditions of irregular 
and intermittent labour liable to crush the spirit or sap the energy of the people. The physical conditions and fundamental economy of the farms were apparently good, and the field of labour all that could be desired by the ardent propagandist of scientific methods, who incidentally had behind him the industrial organisation of the United States of America for the ready supply of the fertilisers, improved implements and agricultural machinery which he recommended.

${ }^{*}$ Hawair, Formosa and Java. - The progress made in these three islands has been selected as affording an instructive example of rapid progress which was secured by the Americans, Japanese and Dutch, respectively, in tropical countries of great natural fertility, which were little developed until they assumed the rule. In each case the instruments of progress were the same, namely, powerful joint-stock companies which obtained control of the requisite land, commanded the necessary capital, and provided for any existing deficiency in the labour supply. In each case the sugar industry was taken as the most important line of advance, though in the case of Hawaii pine-apples, in the case of Formosa tea and camphor, and in the case of Java tea, rubber and other minor articles of produce have played an important part in agricultural progress.

HawaII. - It was only in the middle of the nineteenth century that sugar-making on anything like

* Information collected on the spot in Hawaii, Formosa and Java. 
modern lines was introduced into Hawaii, and at that time there were only five cane plantations in the islands. By the end of the century there were nearly 100 sugar companies established, producing sugar worth more than $\$ 12,000,000$ annually; and since the American annexation at the end of the century the islands have been flooded with American capital and efficient Japanese labour, and the sugar industry greatly developed.

The magnitude of the operations of the present companies may be gauged from the following figures relating to a good average company in the island of Oahu. The capital of the company amounts to Rs. $2 \frac{1}{4}$ crores ( $£ 1,500,000$ ), and the company annually harvests some 5000 acres of cane, averaging 40 tons of cane and 5 tons of sugar to the acre. Natural conditions are certainly favourable, but extensive operations have been undertaken to develop them to their fullest extent. Irrigation is supplied from artesian wells, 500 feet deep, which deliver to the ground level, from which the water is pumped to a height of 400 feet to a reservoir in the hills from which it is distributed to the plantations. In such circumstances the cost of irrigation amounts to well over Rs.200 a year, per acre of cane irrigated, and it is only a good crop which could stand such a charge. The soil receives the best cultivation from steam ploughs, and the cane is crushed in the most modern mills with six separate sets of rollers. Perhaps the greatest difficulty to be surmounted was the labour 
difficulty. The islands themselves provided no efficient labour, and strenuous efforts were necessary to import suitable labour. Emigrants were brought in from a great variety of countries, and the labour of the plantations is now predominantly Japanese and Philippino. The labourers earn over R.s.3 a day, and the sugar companies make effective arrangements for their housing, water supply, fuel, medical attendance and schools. This system of concentrating masses of alien labour on the plantations may not be an ideal one from the social point of view, but the economic success which has been obtained is a standing monument of what may be done to overcome natural difficulties, and the results achieved in building up the large and profitable industry in the course of half a century are most remarkable.

Formosa.-Japan acquired Formosa only in 1894, and with characteristic resolution, immediately set to work to evolve order out of chaos. Having succeeded in that task she turned to the economic regeneration of the island. The Japanese introduced a system of land tenure very similar to that of the Bombay Presidency, and opened up the country by roads and railways. But they did not stop there. By every means at their disposal they attracted capital and enterprise to the task of agricultural development, and especially to the development of the sugar industry. Comparatively little progress took place until 1902, in which year a sugar bureau was established in Formosa, and the Government determined to tackle the problem in 
earnest both from the physical and from the economic point of view, so as to ensure the creation of a profitable sugar industry. The production of sugar in Formosa then amounted to 50,000 tons a year. It was estimated: that the island could produce five times this amount, and a definite programme was drawn up calculated to bring about this result. The physical problem was comparatively simple, since the climate, soil and water facilities were favourable to cane production, labour was fairly abundant, and by the introduction of better canes from Hawaii, combined with scientific manuring and better cultivation, it was shown that the outturn per acre could be greatly increased. The real difficulty lay in the fact that the land belonged to the Chinese farmers who were unwilling to sell their land or to grow cane for the factories. To meet this difficulty the Government issued regulations in 1905 under which a definite tract of country can be assigned to a sugar mill. All farmers in this tract are bound to sell their cane to the mill and can be punished for making sugar themselves by the old, primitive methods, or for selling their cane to anyone else. In addition to this, large subsidies were granted to the industry in various forms. These varied from time to time, but in 1911 subsidies could be obtained for clearing new land, purchasing fertilisers, creating irrigation and drainage works, procuring good seed, erecting repairing shops and organising chemical control. The sums so paid amounted, at one time, to Rs.50 lakhs a year. Last, 


\section{PROGRESS IN OTHER COUNTRIES}

but not least, Formosa sugar has free entry into Japan where the sugar of other countries is subjected to an import duty of Rs.80 per ton. By these measures the desired result has been produced. From 50,000 tons of sugar in 1902 production was steadily increased till in 1910 it reached the estimated figure of 250,000 tons. It was contended that the measures taken were in the interests of the farmers, the millowners and the Government alike. In former times the Chinese farmer had produced a small yield of inferior cane to the acre, had obtained a poor extraction of juice with his primitive stone mills, and had produced a very low grade of raw sugar by his crude methods. It was argued that with better cane and effective handling by means of modern machinery the profits of every one concerned would be increased. So far as Government and the mill-owners are concerned, these predictions have been justified. The consumption tax levied on the sugar manufactured by the Formosan mills amounts to as much as Rs.180 lakhs $(£ 1,250,000)$ in a good year, and the export trade in sugar which was formerly in the hands of Chinese and British merchants has now been diverted entirely into Japanese hands, while the thirty large and numerous small mills have paid very good profits. The case of the Chinese farmer is different. With good cultivation and manuring, a sugar company which has its own plantation can grow 30 tons of cane to the acre from new cane, but the average production on the farmers' fields does not amount to more than 12 tons to the 
acre, for which the mills pay at the rate of $\mathrm{Rs} .8 \cdot 10$ per ton, so that the farmers' gross return, per acre, does not amount to more than Rs.100. It is difficult to ascertain the exact cost of production of cane on any of the factory plantations, since they have not been long in working order and have suffered many vicissitudes from typhoons and other causes, but at the Government Experimental Station at Daimokku, which is favourably situated, the lowest figure at which they can grow cane is Ris. $8^{\circ} 14$ a ton, not including the cost of seed, supervision or interest on capital. About 20 per cent. must be added to the cost on account of these items, and it is safe to say that the cost price of cane in Formosa is at least Rs.10 per ton. The land on which the farmers grow the cane is good rice land on which they used formerly to grow two crops of rice, or one crop of rice and one of sweet potatoes, each year, and these crops certainly yielded larger profits to the farmer than the cane now yields him. It is generally admitted that the farmer does not want to grow cane and loses by doing so. Some mills recognise this and pay him some compensation for his losses. There can be no doubt that he only grows cane for the mills under official pressure. In theory this is not the case, but the Japanese newspapers openly state that it is so, and there is little disguise about it. The success of the sugar industry so far has been obtained by the mills taking all the profits and the farmers bearing the losses. A mill which was paying a 20 per cent. dividend in 
good years paid 12 per cent. in 1913 when a typhoon destroyed a large part of the cane. The farmers who grow the cane for the mill could just keep their heads above water in the good years and must have been almost ruined during that year. This state of things, however, can hardly continue; and in any case the poor cane grown by unwilling farmers would hardly make a satisfactory basis for a large industry. The sugar companies have come to stay. They have erected expensive mills and laid their railway lines through the farmers' fields to bring in the cane. Some mills are buying out the farmers. Possibly this will be the solution of the difficulty in many cases; or possibly they may adopt the system in force in Java, and rent the land from the farmers. However, when the mills plant their own cane they will have to face the serious losses from occasional typhoons which hitherto the Chinese farmers have borne for them. The Japanese Government has fostered and supported the sugar industry in Formosa, and will presumably continue to do so. With the system of import duties, consumption tax, bounties and official support in force, the price of sugar in Japan and the profits of the companies rest on a purely artificial basis. The Japanese Government can at any time make or break the sugar companies by a stroke of the pen.

JAVA.-The example of Java is very instructive, In 1830 General Van den Bosch undertook to restore the finances of Java, by reorganising and stimulating the agricultural system of the island. He did so by 
introducing his system of "forced cultures". 'This system was an extreme example of State interference, with State monopolies, State contractors, and forced labour. Indeed the whole administration was subordinated to the business of growing and marketing certain valuable crops. So far as the government finances were concerned it was most successful; but it inflicted great hardships on the people, and was abandoned after forty years on grounds of equity. It would hardly be expected that a business based on State management and forced labour could prove economically successful, and, in point of fact, the system of forced cultures was not an economic success. It laid the foundation, however, of the presentday success of agriculture in Java. The island had previously stagnated, in spite of great natural resources and an abundant labour supply. The "culture system " demonstrated what rapid progress might be made when to these advantages was added the assistance of Dutch capital and enterprise.

Not only is Java well adapted physically to cane production, but the economic conditions are most favourable. There is an abundant supply of labour at 5 annas a day, and the land which belongs to the cultivators is rented in large blocks by the sugar companies. The land is held either individually or communally by the cultivators, but in either case the sugar companies have no difficulty in arranging with the headman for the lease of the land up to one-third of the total cultivated area of any village, which is the 


\section{PROGRESS IN OTHER COUNTRIES}

limit prescribed by Government beyond which they may not go. The land is occupied by the preliminary cultivation and by the crop for a period of about eighteen months, so the result is that about half the village lands in a sugar district are occupied by the sugar company at any given time. At the end of the sugar season this half is returned to the villagers for rice growing and the other half is rented, and so on from year to year. The rent paid amounts to about Rs.40 per acre for the whole time that the land is occupied, or (say) Rs.30 per acre, per annum. The villagers pay the land revenue amounting to about Rs.7 per acre, per annum. It is stated that the cultivators are glad to let their land for such rents and would let more land to the sugar companies if the law did not forbid it. It gives the cultivators a good deal of work to remake the embankments and to restore the fields to the condition of rice fields after they have been laid off for sugar-cane and returned to them with the cane stumps still in them; but the rent received by the cultivators probably pays them as well as cultivating rice and other crops, and the large demand for labour on the part of the sugar companies means that every man and woman can find a market close to his home for every hour's work that he can spare from his own fields. So far as the sugar companies, however, are concerned the rent is a light one for land of this quality in a densely populated locality where the irrigation facilities and climate are suitable for cane production. The land is hired from year to year 
for one season only ; but the situation amounts to this that the sugar companies enjoy a practical security of tenure. They have erected mills and laid out a network of lines and roads to bring the cane from a distance of 8 or 10 miles, without owning an acre of plantation land. In any country where the use of the land depended on a free annual bargain between the company and a large number of small holders this would be impossible, since the company might at any time be embarrassed or even compelled to stop work for want of land to grow cane. If it were a matter of free bargaining between the companies and the landholders the latter might easily take advantage of their monopoly and demand double the rent that they now get, which the companies could afford to pay. The position is, of course, totally different from the position under the "forced culture" system of fifty years ago, but the old system has left its mark, and, whether the causes be regarded as political or as purely economic, the fact remains that the Java sugar companies are in a position of advantage for securing land and labour for cane production such as no other country enjoys. They have certainly made the most of the physical and economic advantages which they enjoy, for their methods of cane production and sugar manufacture are extremely efficient and well carried out. They are far more economical in many respects than the Hawaiian and Formosan companies, but spend money freely on scientific research, and owe much to the system of organisation and mutual control 
exercised by the Soerabaya Sugar Syndicate which they maintain. The result is that Java sugar dominates the Eastern markets, and not only does the trade dispense with any protection, subsidy or assistance from Government, but it successfully forces its way through hostile tariffs and pays enormous dividends on invested capital. A fundamental condition of the success of these sugar companies is the effective control which they exercise over the land on which they grow their cane. They have introduced a most accurate and scientific system of cultivation and manuring, and much care has been expended on the selection and production of cane varieties most suited to varying conditions. Between 1895 and 1910 the average production of sugar, per acre, was raised from 3.07 tons to 4.15 tons. The methods employed are based on strict economy, and the sugar companies, of which there are about 100, paid anything up to 50 per cent. a year on share capital even prior to 1914 . 


\section{CHAPTER III.}

INDICATIONS OF PROGRESS IN WESTERN INDIA.

IN the previous chapter an account has been given of striking agricultural progress secured elsewhere by various measures, and statistics have been quoted showing that in many cases the agricultural produce has been doubled, and particular lines of a profitable nature developed on a very large scale. It now remains for us to consider what movement of this kind has taken place in western India; and it is disappointing to have to record at the outset that no general or striking progress, comparable with that noted in various cases in the last chapter, has occurred. Even in matters with regard to which progress can be claimed, the statistics do not enable us to state that the outturn of any particular crop, per acre, has increased by a definite percentage.

To take first the question of statistical information, it has already been stated in Chapter I. that the difficulty in securing accurate information of the trend of crop outturns lies partly in the circumstance of small peasant farming, where the peasants keep 
no accounts, consume a large part of their own produce, and sell the rest in markets which make no statistical returns. The greatest difficulty, however, arises from the extraordinary fluctuations of outturn which take place from year to year in conformity with a very capricious rainfall. To turn to the most trustworthy statistics that we have, namely, the trade movements of export crops, the following figures of net export for two important tracts in the Bombay Presidency will show the large fluctuations which take place from year to year :-

\section{Net Export of Cotton from}

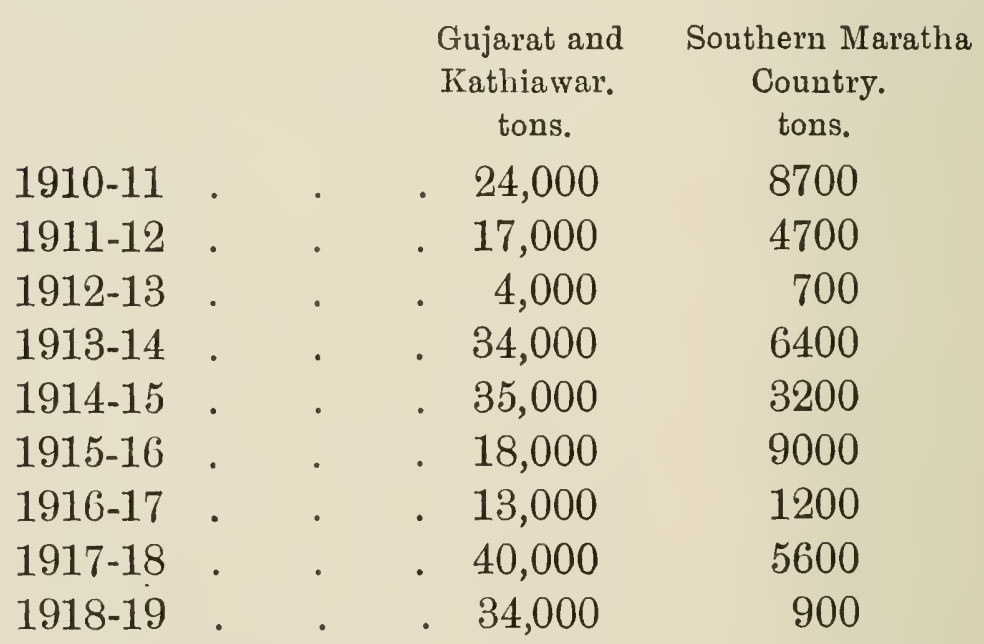

The large seasonal variations, as shown by the official estimates of the outturn, per acre, may be gathered from the following figures:- 


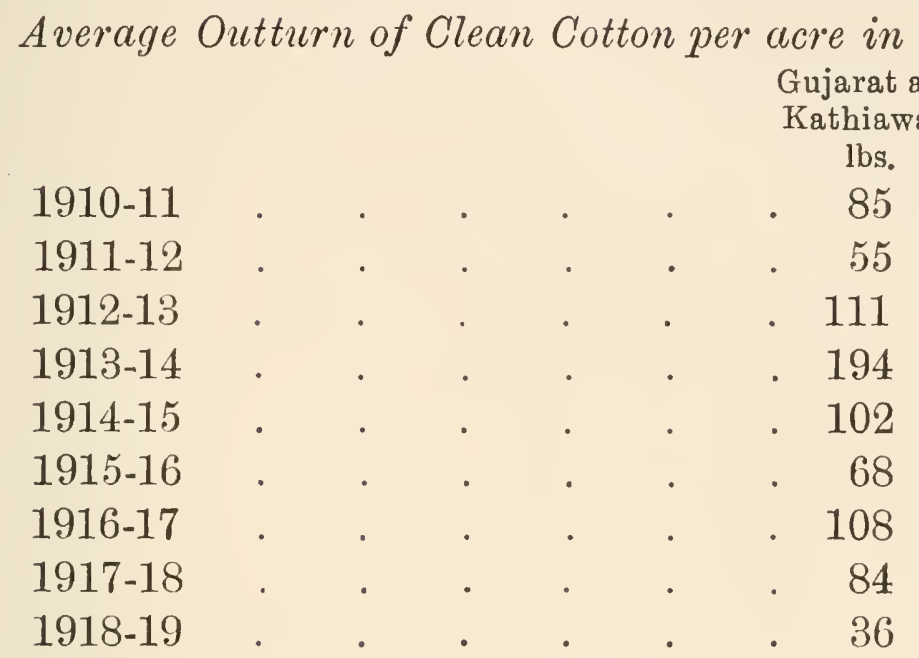

Similar, though smaller, variations occur in the area sown to any particular crop in a given tract from year to year. In bad years large areas lie unsown, and large substitutions of one crop for another are made by the cultivator at the last moment, in accordance with the distribution of the rainfall. In this way the area sown to a particular crop may be double or half what it was in the previous year in a particular locality. It will, doubtless, be recognised that in a tract where fluctuations amounting to 500 per cent. in the outturn and 1000 per cent. in the export of produce are liable to occur as a result of purely seasonal causes, any progress due to improved methods, which might well be regarded as striking if it amounted to 25 per cent. in the course of ten years, is very effectively masked. How then are we to judge of any movement that may be taking place? It is only by indirect methods that we can form any 


\section{4}

\section{PROGRESS IN WESTERN INDIA}

estimate, and in doing so we have to balance facts which fall on the credit side against facts which fall on the debit side of the account.

To consider some important matters which tend to indicate agricultural progress, the first thing that may be mentioned is the steady increase in cultivation which has taken place during the last thirty years, until at the present time there is practically no land fit for cultivation which is not occupied. The great increase in the area of cultivation, resulting from settled conditions and orderly government, had taken place before 1885, the year from which general statistics are available. By that year the cultivated land was already fully occupied in a few of the more advanced and thickly-populated districts such as Kaira, Broach and Satara; but in other districts a steady advance in cultivation took place during the next thirty years, which amounted to about 300,000 acres in the case of each of the more remote districts, such as Panch Mahals, Khandesh and Bijapur, and 100,000 acres, per district, in most of the rest. During the same period the occupied area in Sind increased from 3,000,000 to 9,000,000 acres.

Next we may consider land values and rentals. In the latter days of the Peshwas' rule land in the Bombay Deccan had little or no sale value, and holdings occupied on a permanent basis hardly changed hands at all; but, with the advent of settled conditions and definite assessments land soon acquired a sale value, and by 1860 was changing hands fairly 
rapidly, not entirely to the well-being of the community at large. In recent times the value of agricultural land has largely increased. This is a matter of common knowledge, but a study of recent Revision Settlement Reports issued by the Bombay Government gives some interesting indications of the facts. As might be expected the increase is most marked in the cotton tracts. In the Talukas of Raver and Yaval (East Khandesh), which are typical of concentrated cotton cultivation, the figures are as follows for the average values and rents, per acre, for all classes of land, good, bad and indifferent, viz. :-

\begin{tabular}{|c|c|c|c|c|}
\hline \multirow{2}{*}{ Period. } & \multicolumn{2}{|c|}{ Raver. } & \multicolumn{2}{|c|}{ Yaval. } \\
\hline & Land Values. & Rents. & Land Values. & Rents. \\
\hline $1888-90$ & Rs.48 & Rs.5 & Rs.34 & $\mathrm{Rs} .4 \frac{1}{4}$ \\
\hline $1910-14$ & Rs.165 & Rs.10 & Rs.170 & $\mathrm{Rs}_{\mathrm{s}} 8 \frac{1}{2}$ \\
\hline
\end{tabular}

Showing that in twenty-five years land values increased fourfold and rents doubled. In Dhulia Taluka, another typical cotton tract, land values increased threefold and rents doubled during the twenty years prior to 1918. In Sampgaon Taluka (Belgaum district), which grows cereals as its main crop, land values increased threefold during the thirty years prior to 1913 .

In the non-cotton tracts also the same movement 
was going on. Land in the essentially cereal-growing tracts of the Ahmednagar and Parner Talukas (Ahmednagar district) went up to double and treble its previous value during the thirty years preceding 1916 ; while in the Shergaon Taluka of the same district, which had begun to grow cotton on a fairly extensive scale during that period, land values increased fivefold. Even in the rice area of the Ratnagiri district land values more than doubled themselves between the years 1897 and 1914 .

The above figures give an idea of the enormous rise in land values and rents which has taken place during recent years in western India; and it will be noticed that they refer to the period prior to 1917 when values of all kinds in India began to be seriously affected by causes arising out of the war.

Closely connected with the rising value of land is the question of profits derived from the land. In a country where the bulk of the people are dependent on the land for their living, and where land is regarded as the safest investment for capital, land values are apt to be unduly inflated. This is certainly often the case in India. Land values must, however, depend mainly on the profits that are derived from the land, and it is obvious that rentals must bear a very direct relation to the profits of cultivation. Assuming, therefore, for the moment, that there has been no general or marked increase in the outturn of crops, per acre, it would be expected that, with rising land values and rentals, there must have been an 
increase in the value of the produce. In point of fact this is exactly what we find. The following figures show the rise of price of jowari in Sholapur during the past twenty years, which may be taken as typical of the rise in price of the standard food grains in the country.

Statement Showing the Price per Maund (82 lb.) of Jowari in Sholapur during the Month of Jamuary for 20 Years.

$\left.\begin{array}{lccc} & & \text { Rs. } & \text { As. } \\ 1900 & . & 3 & 15 \\ 1901 . & \cdot & 3 & 12\end{array}\right\}$ (Famine years.)




\section{8}

PROGRESS IN WESTERN INDIA

It is often argued that a rise in the price of food grains is of little or no value to the small cultivator who consumes all the grain that he grows. This, no doubt, is true; but there are large numbers of cultivators who have a surplus of grain to sell, and clearly those cultivators must, to that extent, gain the advantage of the rise of price. It is, however, in connection with the export crops that the rise of price brings most benefit to the cultivator. Taking 100 as the original index, the rise in the price of Broach cotton for the eighteen years between the famines of 1899-1900 and 1918-19 is shown below :-

Statement Showing Index Prices of Broach Cotton in July from 1901 to 1918.

\begin{tabular}{|c|c|c|}
\hline 1901. & & \\
\hline 1902 & & \\
\hline 1903 & & \\
\hline 1904 & & \\
\hline 1905 & & \\
\hline 1906 & & \\
\hline 1907 & & \\
\hline 1908 & & \\
\hline 1909 & & \\
\hline 1910 & & \\
\hline 1911 & & \\
\hline 191 & & \\
\hline 191 & & \\
\hline & & \\
\hline
\end{tabular}




\section{5. . 107$\} \begin{gathered}\text { (Fall due to the out- } \\ \text { break of war.) }\end{gathered}$ \\ 1916 . 140 \\ 1917 . $\quad 251$ \\ 1918 . . 293}

Cotton has always been regarded as a hardy and profitable crop, and, as might be expected, the cultivators have done their best to take advantage of the steady rise in price indicated by the above table, and have greatly increased the area of cotton cultivation during the same period of eighteen years. They would probably have done so far more if the proportion of land under non-food crops in the Bombay Presidency were not already unduly high, so much so, indeed, that in a normal year the Presidency has to import from other parts of India about 500,000 tons of grain, and in a famine year something like $2,000,000$ tons. At the beginning of the century the area under cotton in the British districts of the Bombay Presidency was only 3,000,000 acres. By 1907 it had reached 4,000,000 acres, and under the stimulus of very high prices it was in 1918 forced up to the enormous figure of 4,750,000 acres. In that year 13 per cent. of the occupied area in the Presidency proper was sown to cotton, while in the Districts of Broach and East Khandesh the land sown to cotton amounted to 48 and 46 per cent. respectively, of the total occupied area, and was well over half the cultivated area.

Another very profitable export crop of which the 
cultivators are now beginning to take advantage is ground-nuts. In the early years of the century the area under this crop was well under 100,000 acres. It is now well over 200,000 acres.

An important matter for consideration is the extent to which permanent improvements to the land, of a nature obviously calculated to increase the produce, are taking place. Perhaps the most important improvement of this nature that can be made is the construction of an irrigation well. By the help of irrigation wells, cultivators are enabled to grow valuable crops of sugar-cane, potatoes, onions, spices and vegetables, worth, per acre, ten times as much as anything that could be grown without their aid, or in the alternative to eke out the scanty rainfall of a precarious tract and to grow considerable areas of the ordinary crops of jowari, cotton, maize, etc., to a state of excellence which would otherwise be impossible in most years. The number of irrigation wells in the Bombay Presidency increased from 200,000 to 260,000 between the years 1896 and 1912, showing a steady average increase of nearly 4000 wells a year. In addition to this the well-boring operations of the Agricultural Department have, during the twelve years since they started, added a flow of several million gallons, per hour, to the water supply of the existing wells.

The operations of the Irrigation Department add substantially to the agricultural wealth of the country, and as the present programme for the construction of 
new irrigation works in the Deccan is carried out, it should completely alter the face of the country. The following table shows the principal irrigation canals in the Deccan with the area irrigated.

Table Showing Principal Canals in the Deccan, Date of Opening Canals and Area Irrigated.

\begin{tabular}{|c|c|c|c|}
\hline Name of Canal. & $\begin{array}{c}\text { Date of } \\
\text { Opening. }\end{array}$ & $\begin{array}{l}\text { Total Area } \\
\text { Irrigated. }\end{array}$ & $\begin{array}{l}\text { Including } \\
\text { Sugar-cane } \\
\text { Irrigated. }\end{array}$ \\
\hline $\begin{array}{l}\text { 1. Kadwa Canal } \\
\text { 2. Krishna Canal } \\
\text { 3. Jamda Canal } \\
\text { 4. Ekruk Canal } \\
\text { 5. Mutha Canal } \\
\text { 6. Gokak Canal } \\
\text { 7. Nira Left Bank Canal } \\
\text { 8. Godavari Canals : } \\
\text { 9. Pravara Canals : } \\
\text { 10. Nira Right Bank Canal } \\
\text { 11. New Gokak Canal }\end{array}$ & $\begin{array}{c}1868 \\
1869 \\
1870 \\
1872 \\
1874 \\
1884 \\
1885 \\
1911 \\
\text { Not yet fully } \\
\text { opened. } \\
\text { Not completed. } \\
\text { Construction } \\
\text { about to begin. }\end{array}$ & $\begin{array}{r}\text { Acres. } \\
8,000 \\
2,000 \\
6,000 \\
4,000 \\
17,000 \\
9,000 \\
54,000 \\
45,000 \\
57,000\end{array}$ & $\begin{array}{r}\text { Acres. } \\
2,000 \\
- \\
- \\
5, \overline{0} 0 \\
\overline{-} \\
11,000 \\
7,000 \\
16,000\end{array}$ \\
\hline
\end{tabular}

N.B.-The figures for areas irrigated show the actuals for 1918-19, for the first nine canals, and for the last three are only estimates.

The possibilities of irrigation in the Deccan, which an extensive survey has disclosed, are very great, and as the projected works are constructed, the result on the agricultural wealth of the tract should be striking. Another notable land improvement which must be mentioned consists of the construction of field embankments to check erosion and to catch as much silt as possible and as much rain water as is needed. 
Even in the regions of scanty rainfall very heavy storms occur, usually at the beginning and the end of the monsoon, when 3 or 4 inches of rain may fall in the course of a few hours. These storms do great damage to the fields everywhere, and especially in tracts of deep soil, where the land undulates in long slopes. As the surface water gathers volume and velocity towards the bottom of the slope, it cuts deep channels into the soil, ruining the crops that may be standing, sweeping away enormous quantities of fine silt, and leaving behind it broad tracks of damaged land which never gets a chance of recovering its fertility before another similar storm occurs. Much of the best soil is, in this way, washed down and piled up alongside the rivers and nalas, and by the middle of the rainy season a large part of the finest silt and the manure of the cultivated fields is in the rivers, and well on its way to the sea. To control the surface washing the people in many tracts construct field embankments. In doing so they are much handicapped by the smallness of the holdings and by the general lack of co-operation amongst neighbours. The designs and construction of these embankments, also, often leave much to be desired; but in some tracts much excellent work of this kind is done, and going on, as it does, from year to year, renders considerable areas more productive than they formerly were, and must have an appreciable effect on production, though it is impossible to appraise this effect with any accuracy. 
To turn now to the more technical problems of agriculture, it must be admitted that the existing methods of agriculture, sometimes skilful, sometimes careless, usually unnecessarily laborious, show little change or progress. For the most part the cultivator performs his operations by the same methods that his father and grandfather did before him. There are some matters, however, in which a definite change can be noticed. Here, as elsewhere, the plough is the most important agricultural implement. The local wooden plough, though ingenious in design and capable of producing the desired result at a great cost in labour, is not an efficient implement, and it is found that iron ploughs of western pattern will do more effective work with considerably less labour. During the past fifteen years iron ploughs of various patterns have been introduced in large numbers, and keenly taken up by the cultivators. There must now be hundreds of thousands of them at work in the Deccan to the great benefit of the tillage. Efficient tillage is perhaps the most insistent need of the country-side, so that any progress in this direction is very valuable, both as an actual and as a potential gain.

There are many other matters relating to seed, manure, methods of cultivation and the prevention of plant diseases, with regard to which progress has been achieved by scientific propaganda. These matters will be dealt with in detail in Chapter V. Such progress is not yet general, though the aggregate result is considerable. 
We have now considered a number of factors which indicate indirectly that some agricultural progress is taking place, and it is now necessary to mention two factors which point in the opposite direction. One is the ever-increasing subdivision and fragmentation of holdings, which cannot but tend to inefficient production, and the other is the tendency which, in general, both cultivating proprietors and field labourers show, to abate their efforts and reduce their hours of labour as soon as their financial circumstances allow them to do so. These matters are dealt with in detail in Chapters IV. and VIII. The question now arises whether, as a result of all the causes mentioned, any movement forwards or backwards is taking place in connection with agriculture in western India, whether we can claim progress or must admit stagnation or retrogression. As stated in Chapter I. a very useful criterion of this is afforded by any advance that can be shown in the standard of living of the land-holders and labourers, or contrariwise by any falling off in the same. This again is difficult to measure, but two sets of statistical information may be quoted as bearing on the subject. The figures by themselves prove nothing conclusively regarding the condition of the agricultural classes, but they indicate that the population of the Bombay Presidency, three-quarters of which is agricultural, are able to afford, year by year, more conveniences and small luxuries. This is a matter of common observation. They also show the ability of the rural population to withstand a year of 


\section{PURCHASING POWER OF THE PEOPLE 55}

severe famine without resorting to relief works, which must mean that in good years large numbers of people can nowadays put by savings sufficient to tide them over bad years.

\begin{tabular}{|c|c|c|c|c|c|}
\hline \multirow{3}{*}{ Year. } & \multicolumn{4}{|c|}{$\begin{array}{c}\text { Value of Net Imports into the Bombay Pre- } \\
\text { sidency, Excluding Sind, but Including } \\
\text { Native States. }\end{array}$} & $\begin{array}{c}\text { Value of } \\
\text { Liquor Issued. }\end{array}$ \\
\hline & \multicolumn{4}{|c|}{ In Lakhs of Rupees. } & \multirow{2}{*}{$\begin{array}{l}\text { In Lakhs of } \\
\text { Rupees. }\end{array}$} \\
\hline & $\begin{array}{l}\text { Hardware } \\
\text { and } \\
\text { Cutlery. }\end{array}$ & $\begin{array}{l}\text { Cotton Piece } \\
\text { Goods } \\
\text { (European). }\end{array}$ & Tea. & $\begin{array}{c}\text { Sugar } \\
\text { (all Sorts). }\end{array}$ & \\
\hline $1900-1$ & 26 & 65 & 3 & 120 & 55 \\
\hline 1901-2 & 16 & 72 & 3 & 94 & 51 \\
\hline $1902-3$ & 27 & 78 & 3 & 60 & 35 \\
\hline $1903-4$ & 39 & 91 & 4 & 67 & 61 \\
\hline $1904-5$ & 25 & 156 & 4 & 97 & 70 \\
\hline $1905-6$ & 43 & 157 & 4 & 104 & 60 \\
\hline $1906-7$ & 42 & 155 & 6 & 99 & 76 \\
\hline $1907-8$ & 25 & 180 & 6 & 120 & 76 \\
\hline $1908-9$ & 36 & 160 & 7 & 84 & 77 \\
\hline $1909-10$ & 33 & 183 & 7 & 103 & 82 \\
\hline $1910-11$ & 47 & 178 & 7 & 150 & 91 \\
\hline $1911-12$ & 46 & 176 & 10 & 119 & 102 \\
\hline $1912-13$ & 46 & 187 & 11 & 173 & 104 \\
\hline $1913-14$ & 59 & 220 & 11 & 188 & 107 \\
\hline
\end{tabular}

N.B.-The outbreak of war interfered so much with trade movements that no attempt has been made to interpret figures since 1914 .

If the average figures for these five articles of consumption during the first five and last five years, respectively, of this period be taken, it will be seen that in a period of ten years the annual expenditure on these articles increased by Rs.228 lakhs. 
The tendency of the people to hoard gold is well known and the increasing imports of gold into India are a matter of common knowledge. It is difficult to say what part of the total imports of gold into India must be credited to the Bombay Presidency; but a consideration of the figures leads to the idea that in the period referred to in the last table the annual hoarding of gold in the Bombay Presidency increased by about Rs. 200 lakhs.

Summing up the facts noted above, it may be roughly estimated that during the first fifteen years of this century the annual spending capacity of a family of five persons on articles of comfort and luxury (including gold) increased by about Rs.10.

As regards the capacity of the rural population as a whole to withstand the effects of a severe and widespread crop failure, a comparison between the famines of 1899-1900 and 1918-19 is instructive. In 1899-1900 a widespread area was affected, including almost the whole of the Deccan and Gujarat. In 1918-19 the area affected was equally large, and in some respects conditions were worse, since the crops in the west Deccan and Konkan were inferior to those of 18991900, the crop failure was more general throughout India, and the situation was complicated by the fact that there were very short stocks of grain in India, and that the carrying capacity of the railways had fallen off greatly as a result of the war. In 1899-1900 there was an enormous demand for famine relief work, and for the whole period of twelve months, from 
December, 1899 , to November, 1900 , the average daily number of persons in receipt of famine relief in the Bombay Presidency was over 1,000,000 and throughout July, 1900, the worst month, over 1,500,000. In 1918-19 famine was declared in eleven districts, but except in two districts the demand for famine relief work was negligible, and such relief as was given was mainly gratuitous. The period for which famine relief was necessary was practically confined to six months, and during that time the average daily number of persons in receipt of famine relief was about 100,000, and throughout May, 1919, the worst month, less than 150,000 . The contrast is remarkable when it is remembered that the famine relief wage is calculated with reference to the price of the staple food, so that the real wage paid in each period was identical. The experience of those who saw both famines bears out the inference which the above figures suggest, that during the interval the population had greatly strengthened its economic position.

It now remains to formulate some definite opinion as to the agricultural progress which may be taking place in western India. It has been shown that the area under cultivation has been increased about as far as is possible, that land values and rentals are enormously enhanced, that a large, and apparently permanent, rise has taken place in the value of all agricultural produce and especially in the case of export crops, and that the area under export crops 
has been increased so as to take advantage of this fact. Permanent improvements to the land are steadily, if slowly, taking place, and some improvements in the technique and outfit of the cultivators can be claimed. As a result of all these factors we would naturally expect to find that the spending capacity of the cultivators was steadily increasing, and that their power of resistance to famine conditions was greater. This is what we do find. As against all this we must offset the steadily increasing subdivision and fragmentation of the land, and the tendency of many cultivators and labourers to do less work than formerly. The question thus arises: What is the net result of these two antagonistic sets of causes?

The agriculturists of the Bombay Presidency may roughly be divided into four classes :-

1. Amongst those who are designated as agriculturists there are some who live mainly on the rents of lands which they lease to others, or who cultivate their lands entirely by the agency of hired labour.

2. Next come those who work adequate holdings with their own hands, only hiring such labour as is essential to provide for seasonal stress of work.

3. The men who own too little land either to support them or to provide them with work throughout the year. These form a large proportion of the cultivators of India.

4. Last come the landless labourers who work for hire. 
Class 1 have obtained the advantage of enhanced rents due to rising prices of agricultural produce, and in many cases where they formerly used to cultivate their own lands with hired labour, the increased cost of labour has driven them to let their lands for rent. As a whole this class is more prosperous than it formerly was.

Class 2 includes the best cultivators and the most hard-working men in the country-side. It is the men of this class who make permanent improvements to their land, and, where climatic conditions or irrigation facilities permit, will work steadily and continuously throughout the year, and at certain seasons extremely hard. With a suitable holding a man has the means and the incentive to work, and he tends to develop the characteristic of dogged and persevering labour without which peasant farming can hardly be successful. These men have on their side the causes that make for progress and are immune to the opposing causes which have been noted.

Class 3 comprises the men whose holdings are not sufficient to support them, and who spend part of their time working for others. They are the victims of the conditions which arise from pressure of the population on the land, the Hindu law of inheritance and the customs arising out of it. Where a man can find employment for his spare time in his own village, it is possible for him to keep his holding in a thrifty condition; but where he has to go farther afield in search of work this becomes a matter of greater 
difficulty. As a rule this man is of less value to himself or to the community than the man who can devote his whole time to his own holding. He knows that he does not depend on his land for a living, and consequently his cultivation is usually inferior and his outturn less. On his land he spends part of the year playing at the casual cultivation of a few acres, which will yield him a poor return for the time that he spends at it, and he is often away from his holding when climatic conditions demand that the essential tillage should be done. His efforts often amount to no more than drilling seed into untilled land with the help of borrowed bullocks, and reaping what poor crop results. When the crop is reaped he is in no hurry to exchange an easy life for the more strenuous one of a hired labourer. He hangs about his home and reduces his standard of living until he is again driven to look for work by sheer necessity. There are, of course, many individuals in this class of whom the above remarks are not true ; but frequently the men of this class are the victims of their circumstances. They have little incentive to strenuous labour; their organisation is bad, whether as land-holders or as hired labourers, and they suffer from the evils of casual and intermittent labour, which in time react on their character. Speaking generally, they have not been able to take advantage of the factors which make for progress, but have suffered from the opposing factors. Except in so far as they have been able, as labourers, to take advantage of the higher rate of wages and the 


\section{PROGRESS OF THE VARIOUS CLASSES 61}

more constant demand for labour which are prevalent nowadays, their condition is no better than it formerly was, indeed some observers consider that it is worse. They hold in their custody a large part of the agricultural land of the Presidency, and, so far as this land is concerned, they bar the way to progress.

Class 4, the landless labourers, remains to be considered. The condition of this class has certainly improved during the last twenty years; and though in the last few years the rise in the price of necessaries about neutralises the general rise in money wages, still the constant demand for labour enables the more enterprising men to pick and choose. Many men now move freely to distant towns which offer the best prospects, while others who prefer field work do equally well by following round the rice, jowari and cotton harvests, or by obtaining work on the sugarcane crop of the canal areas. They have developed an independent attitude and secured a position of relative strength which enables the more energetic ones to earn larger real wages and the less energetic to do shorter hours of work.

The above remarks are an attempt to estimate progress amongst the different agricultural classes. Circumstances, however, vary greatly in different localities. In the tracts of scanty and precarious rainfall anything like continuous progress is very difficult to secure in the absence of irrigation facilities; and it is mainly in the more favoured tracts that the progress noted above has taken place, and, in particular, 
in the cotton districts. To sum up the situation in a few words, agricultural progress has taken place in western India, but the pace has been slow-slower than it has been elsewhere, slower than it need be there. 


\section{CHAPTER IV.}

\section{HOLDINGS.}

IT is generally recognised that in farming, the size, shape and constitution of a farm are matters of much importance to success. In theory the standard would be fixed by economic considerations in accordance with the nature of the farming attempted. In practice it is found that in different countries the standard varies enormously in accordance with the pressure of the population on the soil, the laws of inheritance and historical causes. At one end of the scale we find huge sugar estates controlled by joint stock companies which command the most efficient labour-saving devices and harvest thousands of acres of cane every year. At the other end of the scale comes the two acre holding of the Japanese peasant who wields his hoe from morning till night, and treats each plant in his field to a separate dose of liquid manure. In England the economic standard recently prescribed by good * authority is 2000 to 10,000 acres for a farm run on business principles. In some of the western states of the United States of America the standard aimed at by the Government and largely maintained * "Agriculture After the War," by A. D. Hall. 
by the working farmer is 160 acres for dry farming and about a quarter of that area in the case of irrigated land. Even granting uniformity of physical conditions it is clear that variation in the capacity, resources, and ambitions of the farmers will demand farms of corresponding variety, and no one would attempt to prescribe a rigid standard for any country; but within elastic limits definite standards are indicated as most suitable to definite types of farming both on economic and on social grounds. Some countries have recognised that the distribution of the land is a factor of vital importance to agricultural production, and have not hesitated to break away from their historical and legal traditions with a view to divide up the land to the best advantage. Other countries are aiming at smaller results of the same nature, but without adopting such drastic measures. In western India peasant farmers dominate the situation. We find them everywhere, either as proprietors or as tenants. This is a condition to which many countries aspire, and the present system of land-holding would be satisfactory if it were not for the fact that the pressure of population on the soil and the working of the Hindu law of inheritance have resulted in the splitting up of a large proportion of the cultivated land into holdings which fail to conform to any reasonable economic standard. This result is a common experience of countries where similar conditions have existed, and the evil is commonly referred to as "the subdivision of holdings". In India the problem presents two 
distinct features. The first is that the holdings tend to become very small. The second is that individual holdings, whether large or small, tend to become broken up into a number of separate plots, often situated at a considerable distance from each other. These two tendencies differ both in their origin and in their results, and it is necessary to distinguish between them. It is proposed to designate the former as "subdivision of holdings," and the latter as "fragmentation of holdings".

The term "subdivision" refers only to the size of the holdings. Subdivision must tend to occur in any thickly populated country when the number of persons, dependent directly on the land, increases; but the tendency is found to bear a very direct relation to the law of inheritance which is in force. In the Bombay Presidency it is governed by the Hindu law of inheritance, the operation of which is more marked in its effects than the law of any other country, since it gives to each male member of a family an equal share of the family property from the time of his birth, and allows him to claim a partition at any time. There is much to be said in favour of the subdivision of land as tending to a widespread and equitable distribution of wealth and opportunity amongst a large number of persons, and as giving to a large proportion of the people who cultivate the land a direct interest in and attachment to it. It is only when subdivision becomes very excessive that 
its action is undoubtedly harmful and that remedial measures are clearly indicated.

"Fragmentation," on the other hand, is an unmitigated evil for which no advantages can be claimed. It consists of the splitting up of a single holding into a number of separate plots situated at a distance from each other. It arises, not directly from the Hindu law of inheritance, but from customs connected with that law, and has its origin in a desire to provide an automatic method of securing a mathematically accurate partition of a holding amongst the heirs. Thus, supposing that a man dies holding 9 acres of land divided into three plots of 3 acres each, and leaves three sons, it might be hoped that each son would take a solid plot of 3 acres, settling with the others in money the balance arising from any difference in the quality of the different plots. This, however, seldom happens, but, on the contrary, each plot will be split up into three subplots of 1 acre each, and a sub-plot in each place assigned to each heir, so that each of the three holdings made out of the original 9 acre holding will consist of three separate plots of 1 acre each. Nor does the inconvenience end there; for the partition is effected in such a way as to secure an equal partition of good and bad land in each plot, and often leads to a division into long narrow strips. In the case of rice fields consisting of a terraced slope this fragmentation is very marked, for each heir will aim at getting a share of each terrace, and sometimes 
there is an arrangement for the heirs to take each share, turn and turn about, so that the property owned by each man in any plot of land amounts to the right of temporary cultivation rather than the ownership of the land. This custom of fragmentation, together with the Hindu law of inheritance, has resulted in splitting up the land into an enormous number of plots in which a large proportion of the population have some share, however small. It is not peculiar to India, but occurs also in France, where the law of inheritance operates in the same direction, and it is recorded ${ }^{*}$ that in some parts of France, the size of an individual share has been reduced to a single vine or a single tuft of lucerne grass. In Switzerland, also, in Japan and in parts of Germany the evils of fragmentation have been very marked.

There is nothing new in this state of affair's in India. Colonel Sleeman, $\uparrow$ writing from the Nerbudda tract in 1844, enlarges on the great evil which in ryotwari tracts arises from the eternal subdivision of land by the law of inheritance which gives each son the same share. "Every holding," he says, "becomes subdivided when the cultivating proprietor dies and leaves more than one child, and as the whole face of the country is open and without hedges, the division is easily and speedily made. Thus the field-map which fairly represents an estate one year will never

* "Economie Rurale," by E. Jouzier, pp. 347 and 352.

†"Rambles and Recollections," by Colonel W. H. Sleeman, 1844. 
fairly represent it five years after; in fact we might almost as well attempt to map the waves of the ocean as to field-map the face of any considerable area in any part of India." In another place he says: "I have heard Hindu and Mohammedan land-holders all equally lament the evil effects of the laws by which families are so quickly and inevitably broken up, and say that it is the duty of Government, as the great proprietor and leaser of all the lands, to prevent the evil by declaring leases (i.e. holdings) indivisible." While, however, there is nothing new in the nature of the evil, its intensity has much increased in recent years. Dr. H. H. Mann, writing * in 1918 of a village in the Poona district, gives the following information regarding the size of the land-holdings at different dates. In 1771 the average size of the holding was 40 acres. By 1818 it had fallen to $17 \frac{1}{2}$ acres. From 1820 to 1840 it remained constant at 14 acres, and by 1915 it had been reduced to 7 acres. Of the total number of holdings in the village 81 per cent. are now under 10 acres in size, and 60 per cent. under 5 acres. Further, these holdings have been fragmented into 729 separate plots, of which 463 are less than 1 acre, and 112 less than one-fourth of an acre.

In calling attention to the excessive subdivision and fragmentation of the land in the Bombay Presidency it may be stated, once and for all, that

* "Land and Labour in a Deccan Village," by Dr. H. Н. Mann and others (Oxford University Press). 
there is no intention of opening the discussion of the relative economic advantages of large and small farming. The spirit of Hindu law and the spirit of Indian agriculture favour a wide distribution of the land and its cultivation by peasant farmers; and it is not in any way desired to suggest that the formation of large estates, worked on a capitalistic basis, would be more suitable or desirable for the people of the country, either from a social or from an economic point of view. All that is intended is to make it clear that the principles of subdivision and fragmentation have been pushed so far that in many localities the great bulk of the land is seriously affected, and there is hardly a holding that will now conform in size and shape to economic requirements. The distribution of the land amongst the peasants is such that a large and increasing proportion of them have not got an economic holding. In many cases this presents grave difficulties to effective cultivation even by existing methods, and offers a fundamental obstruction to the introduction of improved technical methods or economic organisation calculated to increase the quantity and value of the outturn or to cheapen its production. It is not with a view to interfere with the fundamental conception of the peasant farmer that any suggestions are made, but in order to render possible the creation and maintenance of small but economic holdings on which a peasant farmer can take adequate advantage of the natural facilities which exist, and can improve his 
technical and economic outfit to an extent which will enable him to meet the competition of farmers in other countries, and so to maintain his family in comfort and to hand on his holding intact to posterity. Before making any suggestions it is necessary to describe in some detail the existing conditions of land distribution in western India and to consider the measures which have been adopted in other countries to deal with a similar situation. The facts in question are set forth in Appendix I. and Appendix II., at the end of this book, for the benefit of those not acquainted with them.

From the facts recorded in Appendix I. it will be recognised that in the Konkan, the west Deccan and parts of Gujarat, the land has become subdivided to an excessive extent and fragmented in a manner which is generally recognised to be intolerable. The average holding of rice land in the Konkan is only 2 or 3 acres, and a single field of an acre in area will often be divided up into eight or nine separately-owned plots. An extreme case, not quoted in Appendix I., may be mentioned where a holding of $2 \frac{1}{2}$ gunthas * was partitioned amongst five brothers, so that each brother got a holding of half a guntha, and each of the brothers cultivated each of these five holdings in rotation. The extent of the fragmentation even in the case of the larger holdings will be appreciated from case III. in Appendix I.

* 1 guntha $=\frac{1}{40}$ of an acre. 
Cases IX. and X. show the state of affairs in Gujarat -holdings which average only 4 or 5 acres, fields of an acre divided into eight or nine separate plots, and extreme cases where fields of less than an acre contain as many as twenty-five separate plots. In the west Deccan the case is similar, though the evil has not developed so far; and even in the tracts where the pressure of the population on the soil is much less, it is clear that the same causes are tending to produce the same effects.

To sum up the evil effects of excessive subdivision and fragmentation of land, they may be stated as follows :-

1. They impede current cultivation and waste time.

2. 'They prevent permanent improvements to the land.

3. They prevent a man from living on his farm.

4. They prevent any orderly organisation of labour or capital.

5. They frequently result in second crops not being grown.

6. They sometimes send land out of cultivation altogether.

7. They cause enmity amongst neighbours leading to litigation and permanent feuds.

8. They produce a generally uneconomic situation.

If it were only a small proportion of the land that was so split up the matter would not be serious; but in many tracts the great bulk of the land is affected in this way, in other parts the tendency towards 
excessive subdivision and fragmentation is seen, and everywhere indirect damage is being caused; for there is no such thing in the country as a permanent farm. Subdivision and fragmentation of land occur as each generation enters into its patrimony, and this precludes anything like the idea of steady and orderly development. When it is realised that the evils enumerated above are already pressing heavily on a large and increasing proportion of the land, putting it outside the possibility of effective cultivation or economical development, the necessity for some remedial action will be appreciated.

In Appendix II. it is shown how in other countries similar causes have produced similar results and the remedial action adopted to meet the difficulty is stated. The facts set forth in Appendix II. make it clear that in other countries--

1. Excessive subdivision and fragmentation of holdings have directly resulted from laws of inheritance which, on the death of the father, distribute the land amongst his children.

2. Though in several countries the peasants have made strenuous efforts (amounting in some cases to an agreement to ignore the law of the land) to preserve the holdings intact, they have failed to accomplish their object adequately.

3. Remedial legislation has been found necessary, and has been adopted in a large number of the most progressive countries to remedy the evils caused by their law of inheritance. 
4. In some countries where the law of inheritance does not favour subdivision, the new legislation has aimed at the partition of large estates, while in other countries where the law of inheritance does favour subdivision, the new legislation has aimed at the enlargement and consolidation of the existing small holdings. At first sight it may seem that this involves the acceptance of two opposing principles, but in reality this is not so, since the object in either case is to create and to maintain reasonably sized and reasonably situated economic holdings for peasant farmers.

5. To secure this end legislation has been drastic, involving the principles of

(a) Compulsory expropriation.

(b) The compulsion of all concerned to accept restripment when a certain fraction of the land-holders desire it, and in some cases even without the desire of a certain fraction.

(c) Subsequent indivisibility of the reconstituted holding.

(d) The exemption of the reconstituted holding from seizure for debt, involving the condition that loans cannot be raised on the security of the holding.

(e) Not allowing the reconstituted holding to be combined with other holdings.

6. In all cases the extreme benefit that has resulted from such remedial measures is clearly recognised In some cases the value of the land is said to have trebled, in other cases to have increased over 60 per 
cent.; and there is a general consensus of opinion as to the increased yields of crops obtained by reason of these measures and as to the reduction in the cost of production.

From a study of the action taken in other countries it is clear that a remedy can be found for the evils of subdivision and fragmentation of land, and it would be easy to propose drastic measures for the reconstitution of holdings, involving some degree of expropriation and compulsory restripment; but it is certain that such a proposal would be considered as an outrage to Hindu sentiment and would meet with strong opposition. The land-holders, large and small, are, however, fully aware of the inconvenience caused to them by the existing conditions, and many of them would welcome a measure which offered a remedy without introducing the element of compulsion. At present if a man owns 5 acres and has five sons the law compels him to give 1 acre to each son, though he may be well aware that such an arrangement is unsuitable and uneconomic. In other words, the law makes a will for a man which, if he made it for himself, would cause him to be considered a fool. With a view to enable the discriminating land-holder to escape from this predicament, a bill was drafted in 1916 to enable land-holders who wished to do so to constitute permanent, economic holdings not subject to partition. This Bill is printed as Appendix III. For various reasons it never came before the Legislative Council, but it is probable that, had its provisions 


\section{MEASURES SUGGESTED FOR INDIA 75}

become law, they would have already been exercising a remedial effect on the land tenure of the Bombay Presidency. This would almost certainly have been the case had a Land Commission been appointed with some funds at its disposal ; for the situation of many uneconomic holders is so bad that they would be glad to come to any reasonable arrangement that would help them out of their difficulties, and the sight of money "on the table" would have more effect than many theoretical considerations. Objections to the proposed legislation were made on several grounds. On the one hand objection was raised to any tampering with Hindu law, even if the legislation were merely of a permissive nature; and on the other hand it was urged that in the absence of drastic provisions, involving compulsion, rapid progress would not be possible. It was between these two extremes that the Bill attempted to steer a middle course. A third objection was based on the supposed injustice to those who, under the ordinary provisions of the Hindu law of inheritance, would get shares in the land, but who might be deprived of their share by the proposed legislation. This argument refers only to future generations, and to cases where a man, who has no property but land, prefers to leave the impartible holding to one of his sons rather than sell the land and divide the proceeds amongst all his sons. In such cases the younger sons would certainly be deprived of their normal rights under the existing law. But what do such rights amount to? In effect they are as 
follows: The right to own a small plot of land below the economic limit; the right to pretend that one can support a family on 2 or 3 acres when such is obviously not the case; the right to spend half one's time in idleness because the holding is too small to provide continuous work; the right to earn a miserable pittance in good years and to fall back on public funds in bad years; the right to exclude a piece of land from all chance of effective development or normal productiveness. It was with a view to extinguish such rights that the legislation was proposed. The result of a reconstitution of holdings would be more and not less employment on the land; for well-developed land will demand and will support more labour than ill-developed land. At the same time there would be fewer of the large class of men who own a small plot of land and work partly for themselves and partly for others. It is these men who are now least efective either in the rôle of land-holders or of labourers.

So much for the problems of peasant holdings in the Bombay Presidency. It is not proposed to deal at length with the questions of landlord and tenant. Outside Sind the proportion of land in the hands of non-cultivating landlords is not large, and it is only in a few tracts that the situation presents any serious difficulties in this respect. There are parts of the Konkan where rents are very high and where much friction exists between landlord and tenant, and in many localities the land which is given out to tenants on annual lease can be detected at a glance by its 
unthrifty appearance. But there would be little advantage gained by any measures calculated to take the land out of the hands of non-cultivating landlords, merely in order to subject it to the disintegrating forces which now affect peasant holdings so injuriously. When steps have been taken to check the excessive subdivision and fragmentation of peasant holdings, a good case might easily be made out for measures to regulate the relations between landlord and tenant, and to stimulate production on land which now languishes under a system of dual control.

Hitherto the ordinary dry land of the Deccan has been considered, irrigated, if at all, only by the wells which the cultivators have constructed or from the few streams which flow for a short time after the end of the monsoon. It now remains to consider the case of the canal areas, which form a small part of the total cultivated lands, but which have a value quite out of proportion to their area, and which have a potential importance to the Deccan which can hardly be over-estimated. A reference to page 51 will show that large irrigation works have been constructed, from time to time, to supply water to the east Deccan where, as is well known, the rainfall is so scanty and ill-distributed that good years are the exception. In this tract the soil and the climate are excellent for crop production, but moisture is the limiting factor. Storage reservoirs can be constructed on the western Ghats where the annual rainfall amounts to 200 or 300 inches, and sufficient water conducted in canals 
to irrigate $2,500,000$ acres in the tracts where the rainfall seldom exceeds 20 inches and is often so badly distributed that no amount of skill can save the crops from withering. The present area irrigated from such canals amounts to no more than 200,000 acres, and it may be a cause of surprise that the construction of these irrigation works has not been pushed on more rapidly than has been done. A reference to

Table Showing Principal Existing Irrigation Works in the Deccan and the Financial Results of their Working.

\begin{tabular}{|c|c|c|}
\hline Name of Canal. & $\begin{array}{l}\text { Percentage Paid on } \\
\text { Capital Outlay. }\end{array}$ & $\begin{array}{l}\text { Percentage Paid on } \\
\text { Sum at Charge. }\end{array}$ \\
\hline $\begin{array}{l}\text { 1. Kadwa Canal } \\
\text { 2. Krishna Canal } \\
\text { 3. Jamda Canal } \\
\text { 4. Ekruk Canal } \\
\text { 5. Mutha Canal } \\
\text { 6. Gokak Canal } \\
\text { 7. Nira Left Bank Canal } \\
\text { 8. Godavari Canals . }\end{array}$ & $\begin{array}{l}1 \cdot 42 \\
1 \cdot 65 \\
\text { Nil } \\
6 \cdot 94 \\
2 \cdot 20 \\
4 \cdot 23 \\
1 \cdot 40 \\
\cdot 13\end{array}$ & $\begin{array}{l}70 \\
1 \cdot 00 \\
\text { Nil } \\
3 \cdot 25 \\
1 \cdot 26 \\
4 \cdot 23 \\
1 \cdot 03 \\
\cdot 10\end{array}$ \\
\hline
\end{tabular}

page 51 will show that there was considerable activity in constructing these canals between 1868 and 1885 and again of recent years; but an interval of twenty-five years occurred during which little new construction took place. The reason for this is supplied by a consideration of the financial aspect of these canals. The capital outlay involved in the construction of these large irrigation works is heavy, 
as may be judged from the fact that the Nira Right Bank Canal, now under construction, is to cost between Rs.4 and Rs.5 crores. The interest paid on capital outlay in the case of the larger irrigation works already opened is shown in the above table.

The above figures are taken from the last published report of the Irrigation Department for 1918-19, and it will be seen that, except in the case of two small canals, viz. : the Ekruk Canal and the Gokak Canal, the interest paid on capital outlay is very low. It is only ten years since the Godavari Canals were opened, and the returns from them will no doubt improve in time, but the two large canals, the Mutha and the Nira, have been in full working order for many years, and the returns which they make show that, under the present system, irrigation canals in the Deccan cannot be expected to pay more than about 2 per cent. interest on capital outlay, and not much more than 1 per cent. on the sum at charge. It is clear, therefore, that when money borrowed by Government costs 6 or 7 per cent. the direct loss to Government is serious. The value of the canals to the tracts which they irrigate is great, and in indirect ways Government gets from the canals some small financial return not indicated in the figures shown above; but looking at the question from the purely financial point of view these canals are a dismal failure, and, so long as this is the case, it is certain that, for financial reasons, the progress of constructing new canals must be slow, even granting the existence of the best will to develop 
the country and to protect it against famine. Now these canals are models of engineering skill and, from a technical point of view, a standing monument to the efficiency of the Irrigation Department; and the question will naturally arise, "how is it that these canals cannot be made to pay?" The answer is that they can be made to pay provided that capital and skill are attracted to the canals, and the water is used to anything like the best advantage. The soil and climate are excellent, a large rural population exists on the spot, and with the help of the water all the ordinary food grains can be grown to perfection; fruit, vegetables and spices can be produced so far as the limited demand for them will permit; cotton can be obtained to the extent of at least half a bale per acre, and, above all, conditions are exceptionally favourable for growing the very profitable crop of sugar-cane. The only two things that are lacking for really high-class production are capital and skill.

It might be thought that when a canal is opened in these arid regions the owners of the land under command would lose no time in making use of the water provided. But this is not the case. It is only by slow degrees that the people begin to use the water, and it requires twenty years of patient endeavour on the part of the canal authorities before they can get the water fully taken up. For many years a large part of the water is wasted. As an example of this the case of the Godavari Canals in 1918 may be mentioned. It was clear in that year 
that, owing to causes arising out of the war, there was likely to be a food shortage in India, and every effort was made to induce the people on these canals to grow food crops. Later in the year it became clear that, in addition to other causes, a serious deficiency of rain was accentuating the shortage of food. In the Godavari Canals that year there was sufficient water to irrigate a very large area of Kharif (summer) crops, but the great bulk of that water was not taken up, and it was estimated that water sufficient to irrigate 20,000 acres was run down the canals unused and found its way back again into the river. In this way Rs.20 lakhs worth of potential produce was lost to the country on a canal which had been opened seven years previously. This is typical of what happens for years on new canals; but this might be tolerated if it were likely that the land-owners would in time be in a position to make good use of the water. The experience on the older canals is not encouraging in this respect. Wet cultivation requires far more capital than dry cultivation. For effective work the land must be levelled and in many cases drained, tillage is more exacting, and the handling of the valuable crops more costly. Few of the landholders have the necessary capital for the purpose, and few have the requisite skill or business capacity to grow the more valuable crops successfully; and their efforts to grow sugar-cane are often lamentable. There is a small number of really skilled cultivators who grow good crops of about 50 tons of cane to the 
acre and make large profits, a fairly large class of ordinary good cultivators who grow crops of about 30 tons of cane to the acre by a lavish use of manure and water, and a large class of cultivators who through lack of skill, care or capital grow considerably less.

The present situation of the canal areas may be roughly described as follows: The land is seldom levelled or laid off for irrigation in the manner essential to effective production and the economical use of water. 'The fields are greatly subdivided into sizes and shapes which make proper irrigation almost impossible (vide p. 219). As each section of the canal is opened every ten days, for the issue of water, there is a scramble for the water on the part of a large number of cultivators. It is lavishly used and freely wasted, to the detriment of the current crops, and often to the permanent damage of the soil. Some cultivators get their lands overflooded, while others get less water than they need. The prescribed rotation for the issue of water gets thrown out by the unpunctuality of many of the irrigators, and crops then suffer from the long intervals between the waterings. In these circumstances it will be realised that the canal areas are not nearly so productive as they should be, and from this fact arises another set of adverse conditions. The charges for water that can be made are based upon what the worst class of cultivators can afford to pay under circumstances of 
considerable difficulty. These charges are very small as compared with the potential value of irrigation water in an arid tract, so small indeed that, as we have seen, the canals do not pay, and the result is that there are no funds available to equip the canal areas with an adequate system of drainage or an efficient system of roads. On the Nira Left Bank section of perennial irrigation, out of a total area of 81,000 acres commanded by irrigation, 9000 acres have been ruined and 18,000 acres damaged. On the Godavari Canals, which have been opened only ten years, 6300 acres have been totally or partially ruined, up to date, by water-logging and the salt efflorescence that results from it. This water-logging is, no doubt, largely due to waste of water on the part of the cultivators; but experiments have shown that it could be prevented or even cured by effective drainage, if only the financial position of the canals were such as to warrant an increase of capital expenditure.

Now what is the remedy for this? It is not proposed to enter into a disquisition on the details of canal management or to reiterate the disadvantages which arise from the excessive subdivision of the land. All that it is proposed to state on the general question is that, as the new canals develop and the demand for water increases, the principle for general adoption should be to supply the water as far as possible only to people who have put their land into a condition which makes effective irrigation possible, and to those 
who will undertake to use the water, or at any rate to pay for it, every year.

This principle, by itself, will not take us very far along the road of practical improvement. There is, however, a method by which the canals can be made to pay, and the sections of perennial irrigation provided with adequate roads and effective drainage. The scheme* is based upon the outstanding facilities which these canals offer for the very profitable industry of sugar production. The physical conditions for cane production on the perennial canals of the Deccan are as good as any in the world. It is the economic conditions which block the road to the establishment of a prosperous sugar industry. At present raw sugar, known as $g u l$, is produced by primitive methods. This article is in local demand, and is liked by the people of the Deccan, but its use is limited and its keeping properties are bad. It becomes very sticky and deteriorates greatly in damp weather, and is difficult to transport to long distances. A reference to page 51 will show that the present area under sugar-cane on the Deccan canals will be more than trebled in a short time when the canals now under construction are in working order, and the field for cane growing will increase to a much larger extent as the projected canals come into existence. If nothing

* Scheme worked out by Mr. C. C. Inglis, of the Bombay Irrigation Department, who has made a special study of the problems of drainage and improvement of canal areas. 
but $g u l$ is to be manufactured in the future, the local market will be glutted, and the industry will become unprofitable. To obviate this it will be necessary to manufacture sugar, for which there is a large demand in India and all over the world. But if sugar is to be manufactured it must be done by sugar companies working with up-to-date methods and modern machinery. It is very doubtful whether any large sugar company could afford to depend for its supply of cane on the scattered and slowly developing cultivation of cane on a new canal where crops of poor quality are produced by cultivators deficient in technical skill, capital and the most elementary knowledge of business methods. For successful working, at any rate on a new canal, a sugar company must have an estate of its own on which it can grow a large part of the cane required, so that it may secure the raw material of the quantity and quality desired and that too at the time when it is needed. This, then, is the problem: to provide prospective sugar companies with the essential land on the perennial sections of the new canals; and it is to meet this requirement that the proposals referred to above have been formulated.

It is suggested that Government should take up a large area of land under each canal, selected as most suitable for perennial irrigation, level the whole area and provide it with the requisite drains and roads. They will then return to each land-holder in this area 
one-third of the land which he formerly owned, but with this difference that, whereas his previous holding consisted of unimproved land with no irrigation facilities, the area now returned to him would consist of land properly laid off for irrigation, and with rights to a perennial water supply attached to it. The rest of the area would be reserved by Government for leasing to sugar companies. In this way the essential improvements to the land can be made, the requisite skill and capital can be attracted, a profitable sugar industry created, and many of the difficulties removed from which the present system of canal administration suffers. The sugar companies could afford to pay a water rate far in excess of that which the ordinary cultivator can now pay, and in this way the canals can be made to show a profit. It is calculated that by this method canal schemes, which under the present system will pay interest at the rate of 2 per cent., or less, on capital charges which contain no provision for drainage, road making or laying off the land for irrigation, can be made to pay about 8 per cent. on capital charges which provide for these essential developments.

The objection may be raised that a number of cultivators will in this way lose two-thirds of the area of their lands. This is so, but the one-third area of improved land, equipped with rights to perennial water, will be far more valuable and far more productive than the whole of the previous holding. 
There will not be a single man of them who will not have a more valuable holding than he previously had, and better facilities for raising crops and making a living. The scheme would certainly involve a compulsory change in the circumstances of each man; but such changes are a condition of progress.

At present on the perennial sections of the canals the profits and losses are distributed most inequitably. One man has his fortune made for him, another man is ruined. One man finds that the value of his holding has increased tenfold, while another man finds that his holding is completely water-logged, and rendered useless for any purpose. Under the proposed scheme all will share alike, and all will get real value out of the change.

The merits of the proposed scheme may be summed up as follows: The canal areas will be properly developed and the water used to the best advantage. High-class cane cultivation will be possible, and from it the indirect benefits claimed for beet cultivation in Germany (vide p. 20) will be derived. A profitable sugar industry will be created, and the canals will be made to pay.

A choice has to be made between something of this nature and the existing chaos; but it is safe to predict that, for financial reasons, canal construction will not progress rapidly under conditions in which the canals fail to support themselves, and the cultivator of Gujarat has to pay for the waste and unskilful 
use of irrigation water by the Deccan cultivator. It may be thought that undue prominence has been given to this subject; but it must be remembered that the fate of the east Deccan is bound up with these canals; and it is only by means of a sugar industry that these canals can be made to pay. 


\section{CHAPTER V.}

TECHNIQUE.

THERE are three prominent factors in crop production, and it is upon his skill in dealing with them that the success of a farmer largely depends. The matters referred to are cultivation, manure and seed. Each particular tract will have its own problems, but these three factors are of vital importance everywhere. The general facts regarding the progress which has been made with reference to such matters in advanced agricultural countries are too well known to need repetition here. It may, however, be of interest to summarise the replies that were made a few years ago by competent authorities to inquiries as to how far the agricultural progress in various countries was due to each of the three factors mentioned above. Statistics appear to show that during the past century in Europe the outturn of wheat and other cereals has been doubled, and experts in various countries were asked to indicate the proportion of this 100 per cent. increase that could be ascribed to each of the following factors, viz. :- 
1. Improved and increased manures.

2. Better tillage.

3. Improved seed.

4. Better rotations.

The experts consulted generally agreed that outturns had increased from 50 to 100 per cent. during the past century, and in some cases it was declared that the outturn had been trebled. The causes of this improvement were assessed as follows, viz. :-

\begin{tabular}{|l|c|c|c|}
\hline & England. & Germany. & France. \\
\hline & Per Cent. & Per Cent. & Per Cent. \\
& Considerable & 50 & 50 to 70 \\
Improved manure & Most of all & 25 & 15 to 30 \\
Improved cultivation $:$ & 10 & 15 & 5 to 20 \\
Improved seed & $\cdot$ & & \\
Improved rotation & Little except indirect & 10 & \\
\hline
\end{tabular}

It will be noticed that manure secures the first place amongst the causes that have contributed to increased yields, and under the heading of manure is included not only artificial manure, but, in an even greater measure, the increased supply of farm-yard manure due to the larger number of live stock kept, and its increased value due to the concentrated foods that are now fed to the cattle. Next in order comes improved cultivation, which secures the first place in England and the second place in Germany and France. In England, where the first place is assigned to it, the term cultivation is taken to include drainage operations. It is also noted that in many cases where the 
degree of cultivation has not been improved, the cost of the operations has been cheapened, and also that without good cultivation nothing like the full effects of the manure could be secured. Improved seed comes in a bad third, and it is made clear that even such limited advantage can be secured by good seed only when the cultivation and manuring are adequate. Improved rotations are held to have produced little direct results, but have rendered the wasteful practice of the bare fallow unnecessary, and, by adding greatly to the supply of fodder crops, have enabled the farmers to keep more live stock, and so have been an indirect cause of the increase in manure.

Now in western India it must be remembered that climatic considerations govern the situation to a much greater extent than they do in most other countries. Take the case of the Poona district. Not only does the average annual rainfall vary from 200 inches to 30 in the course of 40 miles, and from 30 to less than 20 in the course of another 40 miles, but in a single place the rainfall may be three or four times as much one year as it is in the next. Further, the distribution of the rainfall is as capricious as its quantity. The sowing of the summer crops depends on the rainfall of June and July. During these months the total rainfall may amount to 15 inches, or only to 5. The sowing of the winter crops depends mainly on the rainfall of September and October. During these months the total rainfall may amount to 25 inches, or only to 5 . In these circumstances it 
will be realised that agricultural practices must vary enormously, and it can hardly be expected that the farmer will pin his faith to any particular system of cultivation, any definite dressing of manure or any special kind of seed. The seasonal factor dominates the situation, and the farmer is apt to be a fatalist, to cut his expenses as low as possible as regards cultivation and manure, and to sow mixed crops or mixed varieties, hoping that if one crop or variety fails, the others may succeed. Each year he must be ready to adapt his methods to the exigencies of the season, and occasionally to face a crop failure from which no skill in adaptation, no precision of system can save him. Subject to these considerations, however, experience indicates definite lines of progress. In common with farmers all over the world the annual problem which confronts the Indian farmer is to convert a weedy stubble into a well-tilled seed-bed. This problem largely resolves itself into a question of suitable implements and good teams, matters which are dealt with elsewhere. But even in this matter the question of knowledge and skill is important. It is recognised everywhere that irrigated lands must be ploughed every year; but for dry cultivation the practice varies enormously. In some tracts great efforts are made by the best cultivators to give the land substantial cultivation during the dry season; in other parts a light ploughing or harrowing at the beginning of the wet season are considered sufficient. Long experience governs these practices, and it is a 
fact that for dry cultivation in many tracts light tillage is all that is essential on heavy black soils which crack freely when dry, and in this way (as the saying is) "plough themselves". Speaking generally, however, the preparatory tillage is very defective, even from the local standpoint, and there are very large areas everywhere, and particularly in the east Deccan, which remain permanently infested with deep-rooted weeds, mainly creeping grasses, and which never receive the tillage essential to clean them for effective crop production. The necessity for cleaning the land is so obvious that the state of these fields cannot be attributed to lack of knowledge. Nor can it be attributed, in the main, to want of equipment; for it must be admitted that there are comparatively few cases where a resolute man could not clean his land effectively with a pick-axe in the course of a few years, and keep it clean by the exercise of a little care. The root cause of all this derelict land must be looked for in other chapters, but the facts can hardly be ignored when considering the technique of the cultivator.

In the matter of after-cultivation the practices of the best cultivators are admirable. Good cultivators in Gujarat interculture their cotton crops repeatedly with a curved blade-harrow during the breaks in the rains, thus removing the weeds and making a fine mulch to conserve the soil moisture. In Khandesh the practice in this respect has greatly improved of recent years, but over much of the Deccan such 
operations are neglected or done in a careless manner; indeed, many cultivators sow their crops so badly that effective interculturing is almost impossible. The conservation of soil moisture by means of a fine mulch is the principle which underlies the practice of dryfarming in the arid tracts of America and other countries, about which so much has been written. The conditions under which this system can be adopted to the best advantage consist of a deep, freeworking soil with good capillary powers. In the arid tracts of the middle-west States of the United States of America such soils are given very fine tillage to enable them to take up the moisture that falls. The depth of the soil facilitates the storage of much moisture, which is preserved from evaporation by a fine mulch, while the capillary power of the soil raises it to a level at which deep-rooted plants, such as wheat, can make use of it. In western India physical conditions make the conservation of soilmoisture much more difficult than in the typical dryfarming tracts of Utah and Idaho. The soil is often shallow, and the presence of a porous sub-soil prevents the storage of much moisture. When the soils are deep and retentive, capillary action is apt to be defective, and it is usually a matter of much difficulty to secure a really fine tilth. In spite of this, however, the wheat cultivators do, during the monsoon, store up the soil moisture in this way, with the result that in a favourable year they obtain fair wheat crops during the cold season, even though no rain at all may 
fall between seed-time and harvest. This practice and the interculturing methods referred to above are based on dry-farming principles. The best cultivators make about as good a job of it as is possible with the implements at their disposal and with the conditions under which they work. It is not with regard to tillage only that this is true, but with regard to sowing and spacing the good Gujarati cultivator will get an almost ideal stand of crop by straight and thick sowing followed by careful thinning out. In many other tracts the reverse is the rule, and the crop will be found overcrowded in one place and very sparse in another, to such an extent that it is not uncommon to see a quarter of the field left blank owing to defective sowing.

On irrigated lands cultivation is a much more exacting problem than on dry lands. For many soils light irrigations, combined with the ridge and furrow system, will give good results, whereas the heavy surface flooding which is practised gives poor crops and ruins the texture of the soil. The cultivators of the canal tracts have much to learn in this respect.

To turn now to the important question of manure. The application of some kind of manure to fields in annual cultivation is very generally recognised to be necessary for the maintenance of the soil fertility and the production of substantial crops. In many parts of India, however, both the theory and the practice of the cultivators with regard to manuring vary greatly within a small radius. Let us take some specific cases 
in the southern Maratha country. In the black soils of the Dharwar Taluka, with an average rainfall of 34 inches, the value of manure for unirrigated crops is fully appreciated by the cultivators, and all good cultivators apply it to their fields in such quantities as they can secure. In the Gadag Taluka of the same district, also, where the average rainfall is 24 inches, and the soil, though deep, tends to be of lighter texture, manure is in great demand. Take the case of the Athni Taluka of the Belgaum district, however, with deep, heavy soils and an average rainfall of 23 inches, and the case is quite different. Here farm-yard manure is not used except for irrigated crops, the area of which is insignificant. The cow-dung which is not used for burning is simply thrown outside the village and wasted. Speaking generally, none of the cultivators attempt to manure their fields; and the reason that they assign for this is as follows: the tract is one of small and precarious rainfall, and they say that in bad years manure "burns the crop". There is, no doubt, much in this argument. In a year of short or badly distributed rainfall fields which have had a heavy dressing of manure will often do worse than fields which have had none. There is hardly any question that, with light dressings of farm-yard manure, welltilled soils would in such tracts give better average outturns than unmanured lands. In these tracts, however, very little of the land is well tilled, and much of it is infested with deep-rooted grasses. In such circumstances the effect of manure is lessened. 
Another important factor is this. As a result of short and badly distributed rainfall, the average outturn in such tracts is not large. In many years the crop is so scanty that it will not do anything appreciable to exhaust the soil, while it is not uncommon for the crop to fail completely for lack of moisture. In such a year the land remains practically fallow and is able to recuperate; and if a year of good rainfall should follow a year of famine, the crops will show how much the soil has benefited from the fallow of the year before.

So much for the theory of the cultivators with regard to manure in various tracts. As regards practice we will again turn to the black soils of the Dharwar Taluka. Here, though the value of manure is fully admitted by all, it is probable that at least half of the fields receive no manure for long periods. On the remainder a dressing of $2 \frac{1}{2}$ tons of farm-yard manure, given every alternate year to the jowari crop, is regarded as sufficient to maintain fair fertility for a rotation of cotton and jowari; 5 tons every alternate year is regarded as good practice, and some of the richer men occasionally give very heavy dressings. A large number, however, have to be content with something like 1 ton every alternate year. In the case of the cultivator the difference between his theory and his practice is due to the fact that farm-yard manure sufficient to meet his requirements simply does not exist under present conditions. With a view to test the exact value of farm-yard manure to cotton and 
jowari in the Dharwar Taluka, a series of comparative experiments was conducted on a large number of plots for a period of twelve years, and the result was to show that a dressing of farm-yard manure, to the extent of 5 tons per acre, applied every alternate year to jowari, in the two-year rotation of cotton and jowari, gave an average additional outturn as follows:-

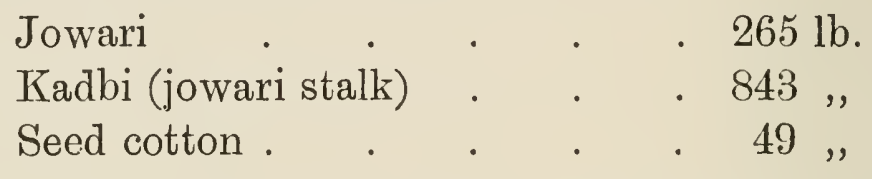

The value of this additional outturn is about Rs.40, and as the cost of the manure required to produce it is only Rs.15, it is clear that this investment yielded a very good profit. Looked at from another point of view, these experiments show that the outturn of jowari and kadbi can be increased from 25 per cent. to 30 per cent., and the outturn of cotton by 10 per cent. by the application of 5 tons of manure every other year. As alternatives to farm-yard manure town sweepings and poudrette * were tried, and were found to give very similar results, the former being rather inferior to farm-yard manure, and the latter markedly superior. They are available only in the neighbourhood of towns of some size. In another series of experiments conducted in the same farm on many plots during a period of twelve years, to determine the best dressing of farm-yard manure for the land,

* This substance is the product of scavenging mixed with dry ẹarth, 
the results were even more striking, especially in the case of cotton, which showed an advance of 25 per cent. from the same dressing which in the previous series had accounted for an enhanced yield of only 10 per cent. It was also made clear that the effect of manure, per ton, is just about the same whether it is applied in dressings of $2 \frac{1}{2}$ tons, 5 tons or 10 tons, every alternate year, the enhanced outturn of crops due to 1 ton of manure being denoted by $60 \mathrm{lb}$. of jowari, $150 \mathrm{lb}$. of kadbi and $15 \mathrm{lb}$. of seed cotton. The cost of 1 ton of farm-yard manure is Rs.3, while the enhanced crop value that it gives amounts to Rs.9. In a third series the increased outturns derived from a light dressing of manure were still more marked, and the general inference to be derived is that the outturn of these crops can be increased 25 per cent. by fairly good dressings of manure, and that the value of the additional outturn is about three times the present cost of the farm-yard manure applied.

The lessons to be learnt from these experiments are applicable to almost the whole of the southern Maratha country, to the west Deccan, Khandesh and Gujarat, a very large part of the Bombay Presidency; and the question will naturally arise as to how the supply of farm-yard manure can be increased or what substitutes for it can be found. As regards the latter question the four substitutes which naturally suggest themselves are artificial manures, oil-cake, green manuring and crude night-soil. Artificial manures have been given repeated trials on a 
large variety of crops, and it has been shown that they can be applied with advantage and profit to many of the more valuable irrigated crops, such as sugar-cane, onions, potatoes, tobacco, plantains, etc. A demand for artificial manures now exists, which amounts to perhaps 1000 tons a year in the case of sulphate of ammonia for top-dressing to sugar-cane, and to a much smaller but growing quantity for complete manures for some of the other crops. For unirrigated crops, however, artificials will not pay at present prices even in the regions of good rainfall, and the only exception yet discovered to this rule is the application of bone meal to rice, which gives excellent results on laterite soils, and the use of sulphate of ammonia for rice on the heavier soils. The case is similar in the matter of oil-cake. It can be applied with much advantage to many kinds of irrigated crops, but it does not pay to apply it to dry crops, with the possible exception of cotton in Khandesh.

So, too, in the case of green manuring, this device can be used most effectively for many irrigated crops, and for sugar-cane a green manuring with san hemp (Crotalaria juncea) will replace the huge dressing of farm-yard manure which many farmers give, to the extent of 150 tons per acre. For dry crops, however, its use is limited by the fact that in most cases the farmer who adopts this expedient gets no return from the green-manured land for a year, and though he will greatly increase the fertility of the land so treated, the smallness of the holdings makes the farmers unwilling 


\section{OTHER MANTITES}

to forgo any sources of immediate gain, even if the ultimate result can be shown to be profitable. This leaves night-soil as the only practical substitute for farm-yard manure which is profitable for dry crops, and it is satisfactory to be able to record that its results are extraordinarily marked on cotton and jowari. A single heavy dressing of crude night-soil will double the outturn of the crops for several years in Khandesh, will increase it by 50 per cent. over a period of ten years in Surat, and will double the jowari crop in Dharwar and add materially, though to a smaller exterit, to the cotton crop. At present this source of manure is available only near large towns, and there is considerable reluctance on the part of many cultivators to use it; but if their fastidious objections could be overcome and they could be induced to conserve this substance as is done so extensively in China and Japan, the manurial problem would be largely solved, and crop production would be stimulated to an extent that is hardly appreciated. Failing the use of substitutes on an adequate scale the question of improving the quantity and quality of farm-yard manure deserves careful attention. That the quality can be greatly improved by correct methods of conservation is shown by the fact that the nitrogen contents of farm-yard manure bought from cultivators was found by analysis to be only one-quarter that of the manure prepared on the experimental farm at Dharwar. If the quantity is to be increased, more live stock must be kept; and this brings us up against 
the difficult problem of cattle in India which is dealt with in Chapter VI. and with the organisation of the farmer which is considered in Chapter VII. It is only necessary here to emphasise the great importance of increasing the supply of farm-yard manure, upon which, in existing circumstances, the soil fertility must mainly depend for many years to come.

In the matter of seed it may be stated that the better class of cultivators adopt a system of mass selection which is fairly satisfactory, and the fact that the smaller cultivators take little trouble in this respect is due to their circumstances rather than to their lack of knowledge. The ordinary food grains of the country have been selected in the course of centuries as suitable to the tracts in which they grow, and the varieties change from one tract to another as the physical conditions change. On the whole the adaptation of the crops to the physical conditions is admirable, and the seed supply is in general found to have a better germinating capacity * than might have been expected, and to be distinctly good except in the case of certain pulses. It is generally recognised nowadays that the possibilities of pure-line selection and hybridisation are almost unlimited, and in such matters a vast field of work lies before the investigator; but even in this matter progress has been made, and fixed types of cottons have been evolved for five different tracts in the Bombay Presidency which give

*Vide Bulletins, Nos. 37, 43, 49, 50 and 55 of the Bombay Agricultural Department. 
an increase of from Rs.4 to Rs.16, per acre, in net return, over the seed which is in ordinary use.

This concludes the general review of the facts connected with the three main factors in agriculture, and the question will arise as to the extent to which practical results have been secured in inducing cultivators to adopt technical improvements which have been proved to give beneficial results. The exact percentages of increase that can be claimed and the exact causes to which they can be ascribed are matters of pleasing speculation, but the difficulties of estimating the increase of outturn have already been mentioned, and organised scientific work on Indian agriculture has been carried on for too short a period and on too modest a scale to make such arithmetical estimates profitable. It is only fifteen years since scientific agricultural investigation in India has been organised so as to admit of continuous effort in any direction, and circumstances have not permitted such rapid development as could have been desired.

It will, therefore, probably be of more use to endeavour to fix with some degree of precision the increase of outturn that is reasonably possible with reference to existing physical conditions and to the knowledge of agriculture now available, and then to consider in more general terms what progress in this direction is being achieved. The following table suggests the percentage of increase in crop outturns that might be obtained in various tracts assuming 
that good, average, hard-working cultivators were established on suitable holdings and were in a position to make their agricultural operations reasonably intensive, each cause of the hypothetical increase being credited with its own share in the result.

\begin{tabular}{|c|c|c|c|c|}
\hline \multirow{2}{*}{ Determining Factor. } & \multicolumn{4}{|c|}{ Percentage of Crop Increase Obtainable. } \\
\hline & Surat. & Jalgaon. & Poona. & Dharwar. \\
\hline $\begin{array}{l}\text { Manure . } \\
\text { Cultivation } \\
\text { Seed } \\
\text { Drainage } \\
\text { Field embankments }\end{array}$ & $\begin{array}{l}30 \\
20 \\
10 \\
10 \\
-\end{array}$ & $\begin{array}{l}30 \\
25 \\
10 \\
-15\end{array}$ & $\begin{array}{l}30 \\
30 \\
10 \\
-15\end{array}$ & $\begin{array}{l}30 \\
35 \\
10 \\
20\end{array}$ \\
\hline Total & 70 & 80 & 85 & 95 \\
\hline
\end{tabular}

The above figures are based on the experience obtained at the experimental farms situated at the places mentioned, and indicate the results that can be obtained by good tillage, timely operations of sowing and interculture, adequate manure, sound seed and protection from surface washing. The exact figure is, of course, a matter of personal opinion, and in suggesting such figures no claim is made for scientific accuracy, but as evidence that the figures are not excessive the case of the Government experimental farms may be taken, on which the outturns have been doubled in the course of a few years by the ordinary methods of good farming indicated above. Another instance that may be cited is the following. 


\section{OUTTURNS ON GOVERNMENT FARMS 105}

In 1917 the Principal of the Poona Agricultural College and some of his assistants made a careful estimate of the average returns obtained by cultivators in a typical village near Poona. The following table shows how these returns compare with the average returns for five years obtained on the Poona College farm under similar physical conditions :-

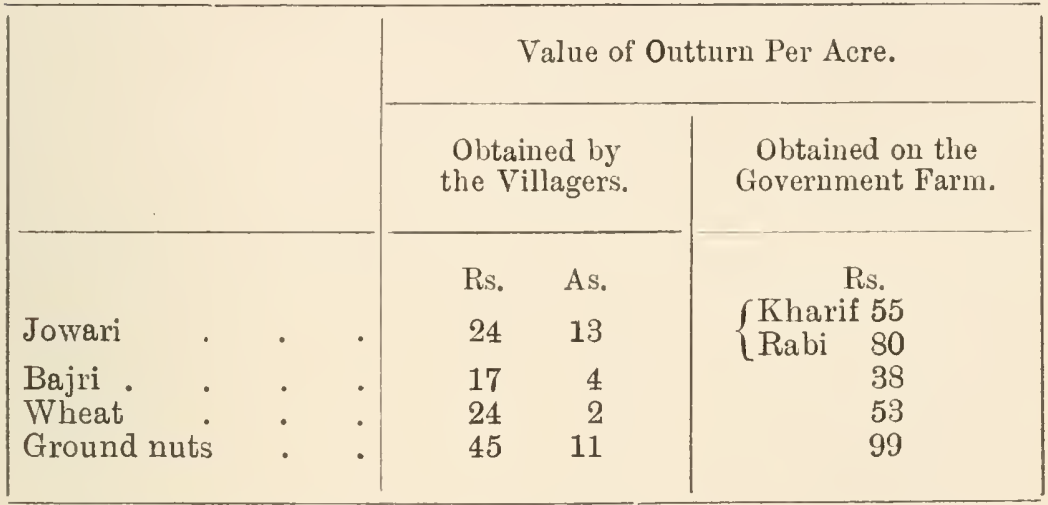

On the Government farm the results were obtained by good cultivation, adequate manure, timely operations and sound seed on a compact area upon which some protection from surface washing was afforded. In the village the results were obtained by poor agricultural practice on fragmented and unimproved holdings, and through the agency of cultivators many of whom relied on agriculture only as a secondary means of livelihood. The figures show that in the one case the outturns were more than double those in the other case.

So much for the present possibilities of the situation. We will now briefly consider what technical 
progress has been made. In the first place improved ploughs of various patterns have been introduced in large numbers and keenly taken up by the people. There is no doubt that they are far more efficient than the primitive wooden plough of the country, and their introduction has in many tracts resulted in a marked improvement in tillage, and large areas of weedinfested land have been cleaned. Harrows and seeddrills of western patterns have been imported and are beginning to find favour, and the seed-drills and interculturing implements of the more advanced tracts have been introduced into the backward areas. In some localities the advantage of manure is now more appreciated than it formerly was, and farm-yard manure is more carefully stored. The products of municipal scavenging which were formerly wasted are now in keen demand, though it must be admitted that up to the present no progress has been obtained in inducing the cultivators to make use of the village supply of this source of manure. Green manuring and the use of oil-cake for irrigated crops have been largely extended, and a small but increasing demand for artificial manures has set in. It is a sign of the times that within the last few years there have come into existence a factory for agricultural implements in the Deccan, and agencies for the supply of implements, seed and manure in many parts. More interest is now taken in securing sound seed and in trying fresh varieties of standard crops; and the pure-line cotton strains evolved by the Agricultural Department 
are now sown on about 200,000 acres, an area likely to increase largely in the near future.

In the case of particular crops many improvements have been introduced. In the matter of sugar-cane the cultivators have much to learn. In preparatory tillage, manuring, planting, irrigating and the handling of the produce many important improvements have been introduced which add to the outturn and lessen the cost of production; and these methods are finding favour and giving good results in common practice. Another interesting crop in India is the potato crop, its chief interest being the large number of fungoid, bacterial and insect diseases from which it suffers. Much progress has been made in the solution of these difticulties, and the cultivators show a practical appreciation of such work.

It is not possible to mention in detail the many lines of technical activity along which work is proceeding, but a few of the more technical branches may be mentioned. In the mycological branch practical remedies have been devised and introduced with conspicuous success for smut on jowari, mildew on grapes and koleroga on supari. In the matter of horticulture many problems relating to the grafting, pruning of fruit trees and the general treatment and sanitation of plantations have been worked out. Advice and assistance in such matters are freely asked for by the public and freely given by the Department. Fruit culture is now being pushed in many districts to the extent of the limited existing demand for fruit. In 
the mechanical line also developments of much importance have taken place. Well-boring operations have located sub-artesian water of considerable volume in definite tracts in Gujarat and Thana District, which will rise to within 20 or 30 feet of the ground level. In the Deccan such water is found in less quantity and with much less certainty. The potential value of the land in the more favoured tracts has largely risen, and the demand for well-boring is far in excess of the capacity of the thirty boring machines owned by the Department. It can hardly be long before private enterprise steps in to fill the gap.

The lifting of water by power-driven pumping plants is a matter which has a great future, since there are many rivers which retain throughout the year water which now remains unused through lack of mechanical appliances, or which, if used, can only be raised to the fields by the extraordinarily laborious device of surmounting the slope by five or six vertical lifts. Many pumping plants have been designed and erected for land-owners by the Department, and in some cases the result has been successful. Speaking generally, this work has not obtained the success that it deserved owing to the prevailing lack of mechanical skill in the country parts, the absence of repairing shops, and want of business aptitude on the part of the ordinary cultivator, who can be seldom brought to understand that, if an expensive machine is to be made to pay its way, it must be worked for all it is worth. Time will cure these 
defects. Power-driven crushers for sugar-cane have also had a limited success, though the obstacles noted above apply to them also. Mechanical cultivation has not been neglected. It has been shown that the heavy lands in the south of the Presidency, now infested with deep-rooted grasses, can be effectively cleaned by steam-ploughing them to a depth of 16 inches, at a cost of Rs.30 per acre; and the demand for this work is so great that it can hardly be doubted that a private company could undertake such operations at a good profit. Motor ploughs of different types have been tried and found to give a light ploughing at a cost of about Rs.7 per acre, but for the reasons already noted the immediate future for such tractors is probably not great.

This concludes the necessarily brief statement of the results obtained by departmental activities and propaganda. Substantial technical progress has been made, but the results secured are very small as compared with the results that might be secured if certain economic obstacles did not block the way. It will be noticed that the important question of live stock has been omitted altogether. This will be considered in the next chapter. 


\section{CHAPTER VI.}

EQUIPMENT.

IT is not proposed to go into details with regard to the implements and appliances with which the farmer in western India carries on his operations. These have been described in detail elsewhere.* It may, however, be briefly stated that, apart from a cart, their value is less than Rs.50 in the case of the smaller cultivators. They are often ingenious and certainly have the merit of being cheap; but as regards efficiency, the man who ploughs his field with a log of wood and two weak bullocks finds himself, when compared with the man who uses the implements and teams common in western countries, at as great a disadvantage as the pedestrian is to the man on a bicycle. It is sometimes said that the Indian cultivator cannot afford to buy up-to-date implements, but it is quite certain that he cannot afford to go without them if he is to compete with the growers of cotton, sugar-cane, oil-seeds and wheat in the more advanced countries. The nature of the implements

* "Rural Economy in the Bombay Deccan," Chapter X. (Long. mans, 1912). 
which he needs has already been indicated, and the means whereby he is enabled to finance such purchases will be mentioned in Chapter VII. All that need be stated here is that his equipment is very defective both as regards implements and as regards fixtures such as sheds, cattle byres and fencing. Improvement in all such matters is essential and will take place slowly as conditions permit. The cultivator is aware of his deficiencies in this respect. His capital is certainly short, but it is due at least as much to defective organisation as to lack of capital or credit that his equipment remains so poor.

The question of live stock introduces more fundamental and more difficult problems which it is now proposed to consider. In doing so the case of cattle * only will be dealt with, since they are of much more importance than all other kinds of live stock. In Europe cattle are kept solely for profit and their treatment is governed by this consideration. In India they are the objects of religious veneration and customary observance which set a limit to their uses and modify their treatment. Some people are averse to castrating bulls, others object to selling cows, and no Hindu may use a cow for draught purposes or countenance the slaughter of cattle. This naturally reduces the profits of cattle-keeping. A bullock is useful only for draught, a cow only for the purpose of

* For full details of the conditions under which the cattle of the Bombay Presidency are bred and fed, see Bulletin No. 85 of the Bombay Agricultural Department. 
producing male calves and, in the case of some breeds, for giving a little milk. A lame bullock or a sterile cow has to be kept alive even though it is useless, and when it dies the village Mahars claim the hide. Add to these considerations the serious risk of epizootic diseases and the heavy mortality amongst the young stock, and it will be realised that it is not an easy matter to make a profit out of cattle breeding. Profits can be made when abundant free grazing is available, or when care and skill are displayed in breeding fine animals which command a high price. What, then, is the meaning of the large number of inferior cows which support life in localities where fodder is deficient, and upon whose breeding and feeding no care is taken? They exist simply in virtue of the free grazing which is available. It would not pay to provide them with expensive fodder, so they remain half-starved. It would not pay to incur trouble or expense on the breeding of such starvelings, so they are allowed to breed promiscuously. They are incidental and uneconomic and may be excluded from the picture. There are many tracts, however, in which the physical conditions are excellently suited to cattle breeding. Breeding depends on the principle of selection in mating, which may be effected by castration in the case of males and by the elimination of the unfit in the case of females. Hindu sentiment makes the former difficult and the latter impossible. These are the fundamental obstacles to improvement in cattle breeding. 
Another serious problem arises as regards fodder. In some localities fodder is habitually short, and every hot season the cattle are reduced to a pitiable condition. They are small in size and breed at very irregular intervals. These qualities are most undesirable from the point of view of economic farming, but under existing circumstances they have a great survival value for the animal, and it is futile to attempt any improvement in breeding until the fodder supply has been improved. In other tracts there is a fair supply of fodder in normal years, and it is only in years of scarcity that the pinch is felt. Such years, however, occur with distressing frequency. When the failure of rain is local it is possible to deal with the situation by importing fodder into the affected tracts, though the transport of fodder is a costly matter, whether the cost be defrayed by the people or by Government; but when the failure of rain is widespread the loss of cattle is great. The famines of 1897 and 1918 each caused a loss of 1,000,000 cattle to the Bombay Presidency, and the famine of 1899-1900 caused a loss of 2,000,000 head; and it was only due to the elaborate measures taken by Government to provide fodder for the affected districts that the loss was not much heavier.

As regards meat production the striking fact is that India is the only country in the world with an enormous supply of cattle from which no profit is obtained by slaughter. The Bombay Presidency contains 9,000,000 cattle, at least 20 per cent. of 
which are valueless for anything but slaughter. If the slaughter of cattle were practised, the normal, annual supply to the butcher would represent at least 10 per cent. of the total number of animals. These facts are the more remarkable at the present time when the price of meat all over the world has gone up to double of what it was a few years ago. In countries where cattle are regularly slaughtered the products of slaughter consist of the meat, hides, horns, hooves, bones, sinews and blood. In India the hides and a limited quantity of bones bring in some profit. The other products are wasted, except in so far as the very restricted operations of butchers in a few large centres are concerned. The loss resulting to the Bombay Presidency from the neglect to utilise these products amounts to crores of rupees annually, and the loss does not end with the potential value of the otherwise useless animals; for the latter continue to eke out a miserable existence and consume the fodder required for the support of the useful animals. Further, it is only by the slaughter of unfit animals that selection of the best animals can be satisfactorily made for breeding purposes, and the race improved. In the absence of slaughter adequate selection becomes impossible. With Hinaus religious sentiment in this matter outweighs all other considerations. The economic facts, however, remain, though they may be ignored.

In striking contrast to the absence of demand for meat in India, the demand for milk and milk products 
is unlimited, and in the larger towns at any rate, this demand is effective. As a result of the causes noted above the supply is very deficient. In some rural tracts milk is fairly plentiful and cheap, but in the towns it is scarce and dear, much of it is dirty and most of it is heavily adulterated. As a result of this it is probable that about 60 per cent. of the population of the larger towns obtain no milk at all except the little that they purchase for their children, and the quality of the milk that can be obtained by the casual purchaser is almost invariably very bad. In China and Japan the people consume no milk, and regard the use of milk or milk products as a disgusting habit; but in India people regard milk as a valuable food, as indeed it is, and there is no reason why, with proper organisation, the milk supply should not be greatly improved.

As compared with the dairy farmer in Europe the Indian dairy farmer is at a disadvantage from the fact that the cows and buffaloes in India give far less milk than is given by any cow whose existence would be tolerated in Europe. Another difficulty is the absence of any succulent fodder during the dry season, except where irrigation facilities occur. To improve matters the obvious technical remedies are to breed pedigree cattle, carefully selected for milk production, and to introduce the use of ensilage. These measures have revolutionised the dairy industry in other countries, and in India there is room for enormous progress in this respect. But the problem of milk 
supply to large towns requires special measures. The present system in India is that of the town dairyman who keeps a herd of milk animals in or near the town for which the milk supply is required. This system was once in force in England, but has now disappeared as a result of effective arrangements for the transport of milk. It is fairly suitable for a small town which is essentially rural in character. The supply of the local gaoli (milkman), supplemented by small quantities carried in from the immediately surrounding villages, will meet the demand fairly well in such a case; but for a city like Bombay with over 1,000,000 inhabitants such an arrangement is quite inadequate, apart from the other disadvantages involved. The town gaoli has his merits and his defects, but in the absence of effective arrangements for the transport of milk he is a necessity. His merits are that he meets a demand for milk which, with present arrangements, could not otherwise be met, and makes it possible for a customer, who takes the trouble to see the milk drawn, to satisfy himself that he is getting pure milk. His defects are as follows :

(a) By keeping a large number of animals in a densely populated area, his operations are in some cases inimical to the sanitary requirements of the locality and conduce to the contamination of his milk by pathogenic bacteria.

(b) Being a dairyman, pure and simple, and not a farmer, he has to purchase all the fodder and concen- 
trated food for his cattle at the enhanced prices which such articles always fetch in towns, and is seldom in a position to obtain any considerable amount of grazing, free or otherwise, for his cattle. The expenses thus incurred necessarily send up the price of the milk which he retails, and sometimes drive him to feed his cattle on foul horse litter.

(c) The animals are kept in unnatural conditions with accommodation which is often insufficient and inferior to that which is usually provided in rural parts. This is apt to react unfavourably on the health of the animals, prevents regularity in breeding, and makes it unprofitable to rear the calves that are born in such conditions.

(d) Much of the manure produced by the city herds fails to find its way back to the fields where it is needed.

The alternative system is to produce the milk in rural parts and to transport it to the cities where the demand for it exists. Along the railway line in Gujarat milk is now produced on a large scale, and separators are to be found in many villages. The trade is well organised within certain limits and there is a large export of cream to Bombay for butter making. This indicates the limitations of the present arrangements. Milk would command a much higher price in Bombay than its cream equivalent, but in a hot country milk cannot be transported for long distances without proper handling. It must be pasteurised and kept cool and clean. This involves 
the use of capital and the exercise of efficient superintendence. Several companies formed with this object have started work in recent years with moderate success, and others are now projected. The difficulties of this business are considerable, but they will have to be surmounted if the milk supply of the larger towns is to be provided for. It is probable that a good deal could be done in Gujarat by agencies which would collect milk in small lots, pasteurise it and transport it to Bombay in bulk; and the Poona milk supply might in a similar way be provided for from the tract of country lying round Sangli; but a dairy company which trusts entirely to the purchase of its milk from others, and produces none itself, is liable to find the quantity of milk available much less than was anticipated, and the seasonal fluctuations very difficult to deal with; while in a year of scarcity the supply may almost reach vanishing point. To meet this difficulty various schemes have been worked out for the establishment of large dairy farms to provide for the larger towns. Given adequate capital and the requisite skill, it is difficult to see how a carefully devised scheme of this kind could fail to pay, at anything like present prices. To secure a suitable site for such a dairy farm some measure of compulsory acquisition would probably be necessary, and it is in this direction that Government can help most effectively. The compulsory acquisition of land is always unpopular, but there are few people who would not agree that some 
such action would be justified, if it can be shown that it is the only way to meet the existing defects in the milk supply of large towns.

The consideration of dairying problems is somewhat remote from the subject-matter of this chapter; but cattle must form an important part of the equipment of the Indian farmer, whether they are kept for milk or for draught purposes, and it is now proposed to note briefly the measures that are being taken for their improvement. Amongst the millions of nondescript cattle to be found in the Bombay Presidency five excellent breeds stand out prominently, and steps are being taken to breed pedigree stock of each distinct breed. Kankreji cattle are being bred for draught purposes and for milk production, Karachi cattle for milk and Mysore cattle for draught. In the near future it is proposed to deal with the Khillari and the Krishna valley breeds. Considerable progress has been made in the case of Kankrejis, which are an excellent breed for dual utility. Selected bulls so produced are put out with breeders on the "premium" system, and as the number of premium bulls increases this system is bound to improve the village herds. Delhi buffaloes are being bred at Sukkur, and the breeding of Gujarati buffaloes will shortly be taken up. All sources of fodder are being explored and feeding problems studied, hay-making by modern methods demonstrated and the use of ensilage introduced.

In the matter of fodder it is not so much that new 
kinds of fodder are required. Many excellent varieties exist, notably $k a d b i$ or jowari stalk. Much of this kadbi grows so coarse that cattle can hardly tackle the hard nodes and the flinty cuticle, and entirely reject the lower part of the stalk. As a result of this it is common to see half of this admirable feed wasted. This waste can be entirely prevented by the use of a circular chaff cutter, and the fodder made to go twice as far as it did before. The use of such chaff cutters is being widely advocated and slowly adopted by the larger cattle owners. Lucerne, guinea grass, and shevari (sesbania egyptica) are being introduced as subsidiary sources of fodder into tracts where they were before unknown, and the problems of improving poor pastures are being worked out with considerable success. To help the owners of cattle to preserve their cattle through the periodic fodder famines which occur, Government maintain reserves of fodder to provide for the opening stages of difficulty, and organise extensive measures for the cutting, baling and transport of forest grass to tide over the famine period. Reserves of baled grass and shredded and baled kadbi are also maintained by the Agricultural Department in various localities, which are designed to provide for the occasional necessities of the better class of cattle breeders who are working with bulls supplied by the Department. In times of scarcity, also, steps are taken to organise the preparation and use of prickly pear for feeding purposes, which makes a useful emergency fodder when the thorns have been 
burnt off. Further, Government maintain a large veterinary staff, and veterinary hospitals are now within the reach of most cattle owners, while preventive inoculation for rinderpest, black quarter and hæmorrhagic septicæmia has now been organised on a large scale. Such measures minimise the loss from epizootic diseases, but the risks from this source are serious. It is probable that in time it will be possible for the veterinary authorities to obtain earlier information of outbreaks of cattle disease and to secure more active support from the people. This will be all to the good; but so long as Hindu sentiment prevents the adoption of measures against cattle disease which have proved effective in other countries, the fear of cattle disease will always remain a nightmare to the cattle owner.

The cow-keepers round Karachi and the buffalokeepers of the Charotar (Gujarat) are experts at feeding milch animals. In parts of Sholapur and Satara the Khillari and Krishna valley cattle are carefully fed; but over most of the Bombay Presidency the feeding and treatment of cattle are very defective. This is due in great measure to the fact that the profits from underbred, nondescript cattle are very small at the best, and all that the average cultivator aims at is to get some slight return in this respect from a minimum of effort and expenditure.

It has already been noted that the religious observances of the Hindus with regard to cattle are a serious 
obstacle to progress in breeding, and limit the sources of profit to be derived from the existing animals. It may also be mentioned that the system of free pasturage on common grazing lands, though it certainly is a convenience to small holders, is as great an obstacle to progress in India as it was in England two centuries ago.* The result is that the cattle industry in India, which should be a source of immense profit to the country, rests on an uneconomic basis and is far less productive than it might be. As common grazing lands come under the plough, methods of feeding are slowly improving; but until the rigid Hindu attitude towards cattle changes progress must of necessity be restricted. Even in this matter, however, signs of change are apparent, and it may be noted that quite recently the Patidars of south Gujarat have modified their caste rules so as to permit the castration of bulls.

* Vide pp. 24, 25. 


\section{CHAPTER VII.}

\section{ORGANISATION.}

Every business man knows full well that the success of any manufacturing enterprise depends on economic considerations as much as it does on technical skill. The projector of a new industrial concern will, accordingly, arrange the scope and magnitude of his enterprise in accordance with general business principles and with the peculiar economic facts of the case. The supply of raw material must be adequate and the market secure; the industry must be of sufficient size to bear the cost of efficient management, the engines large enough to supply the requisite power; the machinery efficient, the buildings properly designed, and the working capital adequate; byproducts must be fully utilised, and there must be no avoidable waste of material or time. When the factory has been suitably located, designed, equipped and financed, the primary requirements for success will have been secured, and the outcome will then depend on capable management and technical skill.

In peasant agriculture it is, from the nature of the case, impossible that the same precision of organisation 
can be secured as in the case of industrial enterprise; but it is certain, none the less, that success in agriculture depends largely on factors similar to those already enumerated. Are the size and distribution of the holding suitable? Is it properly equipped and stocked? These are questions which must be answered before success or failure can be attributed to the personal characteristics and skill of the farmer. To revert to the analogy of the factory. Suppose that the directors of a cotton mill in Bombay were to call in an expert to advise them as to what was wrong with their system of weaving, and the expert were to find that the mill was situated at Dadar, the offices in Byculla, and the godowns at Colaba, that the engines were much too large for the work that they had to do, the number of looms too small to turn out produce sufficient to support the cost of management, and the working capital inadequate. In such a case the weaving expert would assuredly say: "First get all your buildings conveniently situated in one place, increase the number of your looms, and put your finances in order, and then call me in for technical advice". This is the problem that the Agricultural Department so frequently has to face when called in to advise cultivators. It is often the organisation which is wrong, not the technical skill; and though there is usually ample room for improvement in the latter, many obvious improvements which might otherwise be suggested are found to be hopelessly blocked by the economic circumstances. There are 
many physical obstacles for the chemist, the botanist and the engineer to surmount, but the value of their assistance must be seriously discounted where the obstacles which dominate the situation are economic ; and this state of affairs must continue until the economic difficulties are overcome.

First let us consider the internal organisation of the farm. The thing which strikes most observers is that the Indian cultivator trusts too much to a single crop, and that he has few subsidiary sources of industry or income. The man who puts all his eggs in one basket runs an obvious risk, but, apart from that, such a system must tend to concentrate all the farm work at certain seasons and to leave the farmer with little to do at other times of the year. This is what actually happens; and, as a result, people are always searching for some subsidiary industry with which the farmer can fill up his spare time. If technical skill of a kind which is now conspicuously absent can be developed, some use might be found for the cultivator's spare time in working up the raw materials of wood, bamboos or stone into finished products; but at present there is little movement in this direction, and such work is mainly carried on by definite classes of specialised workers. Attempts have been made to get cultivators to take up unskilled work such as cotton spinning by hand, but in view of the efficiency of spinning mills such operations can be justified economically only on the assumption that the cultivator now wastes so much of his time that any work which he does, 
however badly paid, will be better than nothing. Un. fortunately the existing facts in many cases justify such an assumption; but to condemn the cultivator to this uphill and uneven competition is a counsel of despair. The subsidiary industry par excellence of the cultivator should be the breeding and rearing of live stock, which provides an occupation and an income at all seasons, and returns to the soil the manure which is necessary to maintain it in high fertility. There is a good demand for milk and milk products, as well as for poultry, eggs and mutton; and even the smallest cultivators might keep cows, buffaloes, goats or poultry. But it is here that their defective organisation tells against them. Not only are their holdings scattered as noted in Chapter IV., but their villages are congested, and the people live crowded into small village sites which give them no facilities for keeping live stock. Most cultivators do try to keep some farm animals, but the difficulties caused by lack of accommodation in the village are considerable, and the fact that the animals are crowded into their houses in the village, while the fodder stack is in their fields at a distance, and the manure heap outside the village, prevents the orderly development of the industry so far as most cultivators are concerned. This leads to the result that where economic cattle are bred on satisfactory lines, the work is usually done by professional breeders who take special steps to organise the business on workable lines, and not by the ordinary cultivator as a subsidiary occupation to the tillage of 
the fields. It would be of the greatest advantage to the cultivator if he were in a position to undertake the breeding and feeding of live stock on systematic lines as part of his ordinary business ; but this can hardly be done generally until the existing circumstances of scattered holdings and congested villages are modified. Meanwhile the cultivators are unable to take advantage of what should be their principal subsidiary industry, and suffer every year from long periods of enforced inactivity when field work comes to an end.

From the point of view of organisation the size of the holding is a matter of importance, especially in a country where the tillage is done by bullock power and not by hand. As already noted there is room for much diversity of size in holdings, but for the ordinary peasant farmer, in a country where the population presses heavily on the soil, the size of an economic holding is roughly limited in one direction by the maximum area that a pair of bullocks can cultivate, and in the other by the minimum area that can afford the cost of a pair of bullocks. It is not necessary to consider the upper limit, but as regards the lower limit most of the holdings are too small to conform to this ideal. In many parts of India the period for which, under existing practices, farm work can be found for the cattle is very short. Thus in the Konkan the period of farm work for cattle is practically confined to June and July, and in parts of the eastern Deccan, where ploughing is hardly practised, the work consists of harrowing and sowing for the rabi 
crop between August and October. No doubt at such times there is a great rush of work, but at other seasons there is practically no farm work for the bullocks to do. Therefore it is, and must be, the object of most cultivators to keep as few bullocks as possible; and in the east Deccan the best cultivators aim at keeping only one pair for 25 acres, while the average is nearer one pair for 40 acres. In the highly cultivated tracts, where there is little or no free grazing, it will cost about Rs.200 a year to support a pair of large bullocks. If a farmer has 40 or 20 acres, the annual cost, per acre, of maintaining his bullocks comes to Rs.5 or Rs.10. This is a heavy charge, but endurable. When, however, a man in such a tract has only 10 acres, the annual charge, per acre, would work out at Rs.20. This is prohibitive. Such a man would probably solve the difficulty, either by keeping small bullocks and under-feeding them, or by keeping none. Neither alternative is satisfactory. The difficulty of the cultivator and the so-called scarcity of cattle do not arise solely from the fact that sufficient work cattle are not bred or that their price is higher than he cares to pay, but largely from the fact that many of the holdings are not economic units which will support a pair of bullocks. If you were to present a pair of fine bullocks to a man owning 10 acres or less of rabi land in a region where there was little free grazing, coupled with the condition that he must not sell them or give them away, he would have the alternative of starving them or of becoming a cart- 
man himself; otherwise they would rapidly eat him out of house and home. To show that this picture is not exaggerated it is only necessary to make out a rough profit and loss account for the agriculture of any Deccan village, and it will be seen that the cost of maintaining the plough bullocks amounts to the value of about one-third of the gross produce of the fields, and that too in spite of the fact that most of the cultivators declare that they have not got sufficient bullocks to till their fields properly, that many of them make a practice of selling off their bullocks at a ruinous loss at the end of each cultivating season, and that some, who own no bullocks at all, contemplate nothing but the most rudimentary tillage operations, and trust to hiring or borrowing the bullocks necessary for this purpose.

The external organisation of the farmer is hardly less important than the internal organisation of the farm. How can he purchase his necessities and market his produce to the best advantage? His demands on the outside world are few and far between, but such as they are, they have to be supplied. At the least, he needs the implements of tillage, some concentrated manure for irrigated fields, good seed and efficient milk and draught animals; and he often requires an advance to finance such purchases. With good security to offer he can usually obtain a loan from the village money-lender at an interest of 15 per cent. and upwards, but agencies for supplying the articles themselves are very defective; indeed it is 
only in the last few years that agencies have come into existence which aim at supplying implements superior to those which the village carpenter and blacksmith can make, or seed better than can be secured by the casual methods with which the farmers have hitherto been content. The establishment of such agencies may be regarded as a milestone on the road of agricultural progress, and there is ample room for developments of this kind on the part of private firms. Such developments are bound to come in the near future, and deserve every encouragement; but the most striking progress in this respect that has been achieved is due to the co-operative movement, which has made such rapid strides in India during recent years. It was only in 1904 that an effort was made to introduce into India the system of co-operative credit which had proved so successful in parts of Europe, but it was soon evident that the movement was one which contained the elements of success for India, and by 1910 no less than 152 rural co-operative credit societies had been established in the Bombay Presidency, with a membership of 10,000 and a working capital of Rs.4 lakhs. By 1920 the number of agricultural co-operative societies in the Bombay Presidency had increased to 2000 with a membership of 150,000 , a working capital of well over Rs.I crore and a reserve fund of $\mathrm{Rs} .7 \frac{1}{2}$ lakhs. It will be realised from these figures that the co-operative movement is now beginning to have a real influence on the resources of cultivators as a whole. In some tracts its 
influence is still negligible, but in a district like the Dharwar district, where there is a co-operative society in more than one-third of the total number of villages, its influence is considerable. The above figures are exclusive of the non-agricultural credit societies existing in the Bombay Presidency, which have a working capital of Rs.68 lakhs. The societies are linked together by Guaranteeing Unions, and the finance of the movement is assisted by District Banks which tap local capital, and by the Central Provincial Cooperative Bank which is in touch with the larger money market of Bombay. The strength of the system has been demonstrated in recent years of financial difficulty, and the momentum which the co-operative movement has acquired, as a result of the disinterested labours of many enthusiastic workers, permits the expectation that before many years the bulk of the cultivators will be enabled to realise their credit to the full, and to obtain as much capital for current operations or for productive developments as it is safe for them to handle.

There is, however, assistance of another kind, of which the cultivator stands in need for the supply of his requirements and for the marketing of his produce. The establishment of Co-operative Societies for such purposes is a recent offshoot of the credit movement, but by 1920 there were 102 such societies in the Bombay Presidency, of which twenty-six were for the supply of manure, nineteen for the supply of seed and thirteen for the supply of implements. 
There were eight dairy societies, fourteen societies for the breeding of cattle, four for cattle insurance and eighteen for the sale of cotton and other agricultural produce. It is not proposed to insist on the obvious advantages to be derived from such agencies, or to go into the details of the working of existing societies; but a short account of the marketing of cotton may give some idea of the difficulties and loss which the cultivator experiences in dealing with a badly organised and insensitive market, and of the vast field of action which lies open to co-operative effort. The case of cotton is selected because it is the article of the greatest importance that is marketed in western India, and the cotton trade is more fully organised than any other trade which deals with raw material.

In some parts the cultivators bring their cotton to the market and give it to a broker to sell for them, in other parts the custom is for the dealers to go to the villages and buy up the cotton, but in either case a number of small lots will be lumped together and sold in bulk to some purchaser. In grading the cotton there are three main points for consideration, viz. : class (cleanliness), ginning percentage and staple. The grading done is extremely rough and rudimentary. A casual glance will show whether the cotton is unusually dirty and leafy, and, if it is, a slight deduction in price is made on this account. Some indication of the ginning percentage is obtainable by the feel of the cotton, and the dealers will give 
rather more for cotton which this test indicates as having a high ginning percentage; but how inaccurate this test is may be gathered from the following facts. Three samples of seed cotton with ascertained ginning percentages of 22,25 and 28 , respectively, were submitted to a number of dealers in the southern Maratha country. The latter failed to detect any difference between the samples with percentages of 22 and 25, and valued them at the ordinary market rate. They agreed, however, that the third sample was of somewhat higher ginning percentage, and on this account valued it at Rs.2 per naga (1344 lb.) above the ordinary market rate. In point of fact the difference in value between samples (1) and (2) and between samples (2) and (3) was Rs.16, and between (1) and (3) was Rs.32. This shows how insensitive the market is even with regard to a matter so easy to ascertain as ginning percentage. In the matter of staple the qualities which the millowner values are length, strength and uniformity. These qualities are very difficult to assess in the case of seed cotton, and even when samples of clean cotton are submitted to large Bombay firms, the sample which one firm places at the head of the list will be placed by another firm at the bottom. Some assert that the spinning test is the only safe guide, and this test, of course, cannot be applied to seed cotton. The result is that seed cotton can hardly be said to be graded at all for staple, and it is generally assumed for trade purposes that all the cotton of one 
tract is of the same staple, though it may be well known that such is not the case. So much for the inefficient methods of valuation upon which the cotton passes from the hands of the cultivator to those of the small dealer. The dealer, of course, protects himself from loss by the price that he offers. After the cotton has passed into the hands of the dealer anything may happen to it. Long and short-stapled cottons are freely mixed by the dealers, short-stapled seed cotton from Khandesh is taken to Hubli to be mixed at the ginneries with the long-stapled Kumpta cotton, and bales of Khandesh cotton go down to Surat to get the Surat mark and be passed off as long-stapled cotton. Short-stapled cotton from Kathiawar pours into Gujarat by rail and boat for mixture with Broach cotton, and even cotton waste from the Bombay mills is sent up country for purposes of adulterating cotton. Not only this, but the cotton is often deliberately damped before pressing, to increase its weight, though it is well known that this rots the fibre. That such practices take place is a matter of common knowledge, and was freely commented on by the Cotton Committee which sat in 1918. Some people agree that such practices are short-sighted, others call them dishonest; but, as a whole, the trade has accepted them as inevitable. How do they affect the cultivator? Most disastrously. It is the cultivator who pays for all this inefficiency and fraud. The millowner and the exporter know that most of the cotton is mixed and adulterated, and 
pay for it as such, so that the cultivator gets a lower price than he would otherwise get. Further, he, too, is caught up in the vicious circle; for knowing that he will get little or no premium for good-stapled, clean cotton, he is quite content to grow anything that will pass as cotton and to market it with a liberal allowance of leaf and dirt.

The Agricultural Department also is faced with two problems. In the first place how can the cultivator be induced to grow superior cottons when the market is so insensitive to quality that he cannot get a superior price for them? In the second place what is the use of securing the growth of pure strains of cotton in the field when the cotton will not come on the market pure? During the last few years the margin in price between long and short-stapled cotton has widened, and this has tended to help matters. It is possible that in time the trade may realise that the present vicious circle must be broken; though the outcry raised in Bombay during 1920, when the Cotton Contracts Board insisted on a reasonably high standard for Broach cotton, is not encouraging. Much benefit also may be looked for if legislation results from the proposals of the Cotton Committee to regulate the movements of cotton and to secure that every bale shall be stamped so as to show the ginnery and press of its origin. The safest course, however, is for the cultivator to help himself and to organise the cooperative sale of cotton on a large scale. A beginning has been made in this direction, and in 1920 six 
co-operative cotton sale societies in the Bombay Presidency marketed cotton worth Rs.30 lakhs. The work that lies before such societies is of great magnitude and difficulty. Their operations are bound to arouse the enmity of interested dealers; but if they can undertake careful grading and establish a reputation for honest dealing, they will accomplish a great work not only for the cotton cultivators but also for the cotton trade in India. The case of cotton has been treated in some detail, but it is regrettable to have to state that, apart from cotton, much other agricultural produce comes on the market in a dirty and adulterated state, notably such articles as milk, ghi, hemp and wheat. It is not proposed to discuss the circumstances of each case nor to suggest how the several problems should be dealt with; but it is important to call attention to the fact that it is the cultivator who is the ultimate loser, when the marketing of agricultural produce is conducted on a basis of inefficiency or fraud.

There is one other subject which, perhaps, hardly falls under the heading of organisation, but which may be suitably dealt with here, since it is included, together with facilities for credit and marketing, in what may be termed the machinery of argicultural progress. The subject referred to is agricultural education. This is provided for in the higher grades by the agricultural college at Poona and the veterinary college at Bombay, at which colleges some 300 students receive a good scientific and practical education in agriculture and veterinary science. This is 
not a lavish provision for a population of $30,000,000$, but it meets with the present demand for such education in English, and the colleges are freely resorted to by the sons of the larger land-owners and of professional men who wish to take up farming on modern lines or to find employment in some technical department of Government. The agricultural and veterinary departments of the Bombay Presidency are recruited from the graduates of these colleges, many of whom, also, join the staff of neighbouring Provinces and States or of more distant regions such as Burma, Assam and Ceylon. Some have even secured positions as skilled agriculturists in distant parts of Asia and Africa. For the sons of ordinary substantial cultivators special agricultural schools have been established in various tracts where a two year course in practical agriculture is given, with sufficient theoretical instruction to enable the boys to understand the meaning of the practices that they are called upon to follow. The boys are boarded and lodged free, and instruction is given in the local vernacular. At present there are only six such schools in the Bombay Presidency, but Government have approved of a scheme to provide an agricultural school for each district in the near future, as finances permit. In the abstract these schools appeal strongly to popular sentiment, but to ordinary cultivators the idea of boarding schools is unfamiliar, and there is no great rush of pupils to attend them. The advantages to be derived from them are bound to be realised as time goes on, and their influence on 
the agricultural technique of the country-side should in time be considerable. The criticism has been levelled at them that they are costly and that fees ought to be charged. Agricultural education of this kind is certainly more costly than the ordinary education as given in the villages, but, as an offset to this, it is also more effective. The schools are making headway, and to charge fees at this stage would be to check progress. Even when twenty such schools have been established the annual cost to Government will be only Rs.2 lakhs, which is not a large sum when the object aimed at is considered. It is true that the cost of such schools would prevent their indefinite multiplication; but it may be hoped that, before the present programme has been completed, their popularity amongst the cultivators will greatly increase; and, when this occurs, it will be possible to consider the question of charging fees. 


\section{CHAPTER VIII.}

THE HUMAN FACTOR.

IT is a commonplace statement of a certain class of writers that the history of western civilisation is the history of man's emancipation from the tyranny of his surroundings and that the history of tropical civilisation is the record of his enslavement to them. Americans in particular are prone to make such statements; and it is perhaps natural that they should do so, contrasting the enormous and rapid development which they have effected in their own country with the stagnation which they found in such naturally fertile countries as Hawaii and the Philippines when they assumed the rule of those islands. Perhaps they are apt to minimise the part which the great physical advantages of their own country have played in this development, and the almost unique opportunity which was presented to the men who divided up a continent amongst themselves. Still it was not without a severe struggle that they entered into their heritage and turned it to such good account, and we may forgive the complacency with which they regard their handiwork. 
While, therefore, we may deplore the physical poverty of a tract like the Deccan, we may solace ourselves with the recollection that a civilisation which is based on natural advantages, and not on the energy of man, contains within itself the seed of its own destruction. The land may be good or bad, and the plough may be good or bad, but it is the man behind the plough who counts for most in the long run. Let us consider the progress of his struggle with nature in the Bombay Deccan.

The picture of the tropical cultivator leading a life of contented indolence, his simple wants supplied by a bountiful nature, has no relation to the conditions of the Deccan with its thin layer of soil and its light and capricious rainfall. The Deccan picture would rather represent a perpetual struggle in which the cultivator has frequently found himself on his back. The early years of the nineteenth century saw desolation in the land, and the last years of that century saw this calamity averted only by elaborate administrative efforts. So far the victory has been with nature, and the Famine Relief Code, while it secures the best terms for the vanquished, affords evidence of the defeat. If, therefore, we hold that nature can smother her favoured children with too much kindness, we might expect that the niggardliness which she displays to her step-children in the Deccan would brace them to strenuous efforts. In part this is so; but the struggle has been too severe for many. Without its essential equipment the bravest army cannot expect 
victory, nor can its morale survive constant defeat. So it is with the Deccan cultivators, many of whom have neither the equipment nor the confidence that leads to victory.

Let us go into the details of their position. Beginning at the bottom of the scale we have the landless labourer who works for hire, a class which is steadily recruited from the smaller land-holders as the pressure of population in the most densely peopled tracts squeezes them out of the position of land-holders. In former times labourers were commonly employed as saldars, or yearly labourers, and often remained in the same employment for many years together, not infrequently serving the same master from father to son for several generations. Saldars are still to be found in most parts of the country in relatively small numbers, doing the permanent work of substantial cultivators; but the tendency nowadays is for the labourer to prefer to work for daily wages or on the piece-work system, and the long time service of olden days is now most common in the part of Khandesh or Gujarat where Bhils and Dharalas work for the larger land-holders. Formerly it was common for contracts to be made which bound down these people to the conditions of serfs, and it is only in the present time that these classes are beginning to show the independence that other labourers have shown for some time past.

But the change of conditions does not end there. Employers of agricultural labour throughout the 
Bombay Presidency tell the same tale that field labourers are more independent, more difficult to secure and to retain than they formerly were, and that they work less efficiently and for shorter hours, though they draw double or treble the wages. Such statements are heard in most countries nowadays, and we may perhaps discount some of the charges brought against labour by employers who are suffering from a change in economic conditions. So far as the labourers are concerned, their position is this: they have had their bad times, sometimes very bad; and now that economic changes have strengthened their hands, they are naturally going to make the most of the chances that fall in their way. Their condition still leaves much to be desired, and while it is true that an energetic and able-bodied family which is prepared to work hard, is able to live in comfort, according to its own standard, and to put by money, the average labouring family lives pretty much from hand to mouth, even in good times, and subsists with a minimum of the necessaries of life and with few comforts or luxuries. Its standard of living is always very low, and in days of famine or sickness distress is sure to occur.

In the decade ending with the year 1880 agricultural wages commonly ruled below 3 annas a day, after which a sharp rise occurred to about 4 annas. This rate continued until the famine years at the end of the century pulled wages down again to their previous level in many localities. Early in the twentieth 
century, however, wages rose to about 5 annas and continued to rise slowly until in the last few years there has again been a sharp rise, and at the present time, in a normal year, wages in the more prosperous districts amount to as much as 8 or 10 annas a day, and at harvest time rise to 12 annas or more. Real wages, which for rural labourers may be expressed with fair accuracy in terms of food values, had a very chequered course during the last quarter of the nineteenth century. They fluctuated violently from district to district and from year to year, according to the nature of the season, and it was common for them to vary from 4 to 7 sers $(1$ ser $=2 \mathrm{lb}$.) of jowari a day, in the course of every three or four years, if we express the money wages in terms of the standard food, while in famine years the average wage represented less than 2 sers. In the early years of the twentieth century real wages tended to steady at about 5 sers of jowari a day, and in the last few years the fact that the money wage and food prices have both approximately doubled leaves the situation practically unchanged. The above estimate is, of necessity, of a very general nature, and the improvement in the position of the labourer is greater than the figures appear to indicate. The more enterprising and energetic labourers nowadays move freely to the localities where the best wages are available, the less energetic work for shorter hours, and for all classes of labour the demand is now far more steady and continuous than it used to be. A consideration of the difference between 
the rise in daily wages and the rise in wages for piecework will give some indication of this. In the southern part of the Bombay Presidency it is a common practice to have cultivated fields which are infested with deep-rooted grasses dug over by hand once in a long period of years, in order to eradicate the grasses. This is a heavy and laborious operation involving the use of the pick-axe and the crow-bar. Fifteen years ago the contract rate for such work was Rs. 20 per acre, while it is now Rs.75 per acre. It will thus be seen that in the same period in which daily wages rose by a little over 100 per cent., wages for certain kinds of piece-work went up by nearly 400 per cent.

So much for the facts about agricultural wages. But it may be inquired what is the meaning of this rise in wages and of the so-called "scarcity of labour" about which we hear so much nowadays. The explanation often suggested is that the population has been reduced by plague and influenza, and that new manufacturing industries have caused a greater demand for labour and attracted the best workmen to the towns. These considerations are not negligible, but are they sufficient to account for the marked change in the situation with regard to labour which has certainly taken place? The population of the Bombay Presidency (excluding Sind) is roughly $23,000,000$ and there has been little change in that figure during the last thirty years. During that period, however, there has been an appreciable in- 
crease in the area of land cultivated, and the industry and commerce of the larger cities have drawn upon the rural population to the extent of perhaps 500,000 persons. These facts have certainly had an influence on the general situation, and in some localities the influence has been considerable, but by themselves they would not be sufficient to account for the striking change that has taken place in the position of labour ; for there are many tracts where the population has increased and where hardly any of the people leave their villages in search of work. Here, at any rate, it might be expected that there would be little change in the labour supply available. But this is not the case. In such tracts, also, employers have the greatest difficulty in securing workmen at present rates of wages, even in the hot weather when field operations are at a standstill. What is the explanation?

The fact is that since the Indian farmer has had access to the world's markets he has managed to secure a much better price for his produce than was formerly possible. Add to this the fact that during the last few years the world's price for agricultural produce has been greatly enhanced as a result of the war, and it will be realised that the Indian cultivators who have produce to sell must have a larger income than they formerly used to have. They have used this increase in their income partly in buying more necessaries and luxuries (vide p. 55) and partly in doing less work. It is a matter of general comment 
that whole classes of cultivators who formerly used to do their own field work have now ceased to take any active part in field operations. This is said of the Patidars in Gujarat, of the better class Lingayets, in the southern Maratha country, of the Havigs in Kanara, and of the more substantial cultivators everywhere. So also with the smaller proprietors. Many a man who formerly supported himself on his holding during part of the year and was glad to work for hire in the off-season, now finds that he can get on without the latter source of income, and keeps out of the labour market altogether unless exceptionally high wages in the neighbourhood of his home tempt him to forgo his hot weather holiday.

Even in years of serious and widespread crop failure there is hardly any demand for work at famine wages for which only twenty years ago there was such a desperate rush. It is even asserted by careful observers that the keenness of the cultivators to grow cotton is due not only to the fact that they can usually make good profits from it, but also to the fact that it is an easy crop to grow and leaves them plenty of leisure, and it is argued that, for this reason, they will continue to grow it in preference to other crops which yield them a better return, and to sow the same fields year after year to cotton, without any rotation of crops, although they know that this constitutes bad agricultural practice. A competent and experienced critic of agriculture in Gujarat, $\mathrm{Mr}$. Gulabhai N. Desai, makes some interesting com- 
ments on the labour situation in Gujarat in a series of articles which he recently contributed to the "Quarterly Journal" of the Broach Agricultural Association. After deploring the fact that all classes of the rural population in Gujarat now require pleasures and luxuries which they did not formerly want, he continues: "The farmer does not at present do as much personal labour as the farmer of old, nor does his family supply the labour that they used to supply formerly. In my young days I used to see the farmer and his family giving their due share of labour to their ancestral profession. It is not so now. At present the whole labour required in all agricultural operations is done by hired labourers. This is a great drawback." He then states that amongst the agricultural classes of Patidars, Kunbis, Anavalas, Borahs and Rajputs in Gujarat practically no one does any actual field labour nowadays, and he estimates that amongst these classes alone 300,000 ablebodied men have during the last generation been withdrawn from the ranks of active labourers, in this way, and added to the class which lives on the land without doing any actual field work.

We have now considered the two classes of cultivators, those who cultivate their own land, and those who hold no land but work only for hire. Between those two comes a large intermediate class of men who own a few acres of land, the cultivation of which occupies part of their time, and who work for hire at other seasons. It has already been noted (p. 60) that this 
arrangement is not conducive to progress, though it, no doubt, has its advantages from the point of view of an easy-going cultivator with simple tastes and no ambition. These have not the incentive or the organisation that would make them really effective either as peasant proprietors or as paid labourers, and it is the case with them in at least as marked a degree as with the land-holders or labourers that they do less work than they formerly used to do. This general tendency is a matter for serious consideration. In one way it is satisfactory, in another way it is not so. We may rejoice that the raiyat no longer lives in the hand-to-mouth condition of former days when numbers of men were available in any village at a few minutes notice for a wage of 4 annas a day, and when a single crop failure sent a large part of the population flocking to relief works; but we should like to see him use his advantage to strengthen his position. The victory is not yet won, and he cannot afford to stand still while his rivals in other countries are progressing. If each economic advantage gained is to be the signal for a relaxation of effort, if improved methods of farming are to serve not only to increase the crop but also to swell the ranks of non-workers, is any marked progress possible? The question is one which will repay consideration, but in propounding the question it is not intended to suggest pessimism. The economic position of the labouring classes in many countries has changed greatly for the better during the past century, and they have used their advantage, 
in part, to reduce their hours of labour. Few people will contend that incessant labour is in itself a blessing; and when a man has satisfied his necessities he will fix the limit up to which he is prepared to work with reference to his desire for more than the bare necessities of life, in other words, in accordance with his standard of comfort. The standard of comfort of the Indian peasant is low, and his training teaches him to be content with little; but there is clear evidence that the standard of living is rising. The trouble, of course, is that the efficiency of labour and the standard of effort in India, are, speaking generally, already very low, and will hardly bear any relaxation. In the Bombay cotton mills it takes six men to do work similar to that done in Lancashire by one operative, and even then the outturn is less. It is even stated that there are cotton mills, identically constructed, in the Bombay Presidency and in Lancashire, respectively, and that the number of hands employed in the former is ten times as great as the number employed in the latter. In agriculture the following examples give some idea of the relative efficiency of agricultural labour in India. In the West Indies a labourer gets three times the pay of a labourer in the Deccan, yet it costs less in the former place to get a ton of sugar-cane cut and stripped, because the West Indian labourer does more than three times the work of the Deccan labourer. Again, take the operation of cotton pickirg. A woman in India will pick only one-half as much as a woman in Egypt 
and one-third as much as a woman in the United States of America. In the case of heavy labour the inefficiency of ordinary Indian labour is very marked. In California there is a good deal of competition in the matter of well-boring between the hand-borers and the power-borers. It is admitted by both classes that at depths of less than 100 feet hand-boring is the cheapest and that at depths of more than 200 feet power-boring is the cheapest. It is in dispute between the two parties which system of boring is the cheapest at depths between 100 and 200 feet. In India, however, it is found cheaper to use power-driven machines even for depths of less than 100 feet. This is not due to the fact that mechanical skill is readily available in India. On the contrary, such skill is notably deficient. It is due to the fact that labour for heavy work of this description is very difficult to secure, and, when secured, is very inefficient. In the case of some of the lower classes of labourers there is a strong disinclination to do more work than their immediate necessities demand. In the Thana district a man who wishes to engage a daily labourer goes to the hut of a Warli or Katkari and asks the man's wife whether they have sufficient nagli (their ordinary food) for the day. If she says "yes," he passes on to the next hut.

There was a depressing theory known to the older economists as the "Iron Law of Wages," which states that it is impossible to raise wages permanently unless the efficiency of labour is at the same time increased. The general truth which underlies this 
statement was sometimes exaggerated and given undue prominence in cases upon which it had little bearing, and consequently the theory tended to become discredited. It is a fact, however, that people will not go on paying for labour more than it is worth to them, and in the present day some land-owners prefer to let their land to tenants rather than continue to work it and improve it by hired labour, and give as their reason for so doing that they cannot now get good labourers.

If we turn to the standard of effort amongst the smaller landed proprietors, it must be confessed that the present tendency of this class to relax their efforts and give up all active part in the cultivation of their land the moment that they can see their way to do so is somewhat disquieting. A large land-owner may well be fully occupied in directing and supervising the labour engaged on his farm, but when we find numbers of land-holders, who own 40 acres or less of dry crop land, sitting idle and leaving the work to hired servants, it is clear that they are simply an incubus on the land. Contrast this attitude with that of the small American farmer in the arid tract of the Middle-West, who wrings a hard living from the soil by wheat growing on a quarter section farm (160 acres). A single man will work the whole farm with four horses and temporary assistance at harvest. time. His work is very strenuous and continuous, but year by year he is able to invest fresh money in his holding, and large areas which were waste only a 
short time ago are now covered with prosperous homesteads. Or take a man in the same locality or in California who has an irrigated holding of 20 acres. He may be worth 1 or 2 lakhs of rupees; yet he not only works the land himself, but frequently does the whole of the work, his hours being from sunrise to sunset. The American holder of somewhat less means will not disdain to work for hire as a navvy in any spare time that he can filch from his farm, and will thus provide himself with additional capital for developing his land. In India does any man worth Rs.20,000 engage personally in field labour on his own farm, or does any farmer worth Rs.5000 employ his spare time in working for hire? Such instances must be very rare. The natural tendency of such men is to engage labour for the performance of their current field operations, and to finance any permanent improvement that they may contemplate by. means of a loan. Of course it may be said that the reason why the American farmer does not hire more labour is that it is not available, and that the reason why the Indian farmer hires so much labour is that it is available. This is so. But it is the heavy bill paid for labour which is often inefficient that runs away with the profits of the substantial cultivator. The cry nowadays is that owing to the rise in wages the position of the small cultivator who gets his work done by hired labour has become very difficult. The onlooker may feel inclined to say "would that it were impossible". If the wages for field labour were 
to rise to Rs.2 a day, the small land-holder would probably see the advantage of performing for himself most of the work for which he now pays wages, and his labour bill would go down instead of going up.

When we contrast the standard of effort in one country with the standard of effort in another and say that the farmers in one country are hard-working and that the farmers of another country are indolent, it does not, of course, mean that all the farmers in the one country are hard-working or that all the farmers in the other are indolent. It is not to be expected anywhere that all will be models of diligence and perseverance; but in countries where a large proportion of the farmers (say 60 per cent.) are keen, hard-working men, we may expect to find agricultural progress, whereas in countries where only a small proportion (say 20 per cent.) of the farmers have developed these characteristics, we cannot expect to find any general progress. Peasant agriculture is most exacting in this respect, and without strenuous application and dogged perseverance the cultivator cannot expect success under ordinary conditions. The proportion of hard-working cultivators, therefore, tends to be much the same thing as the proportion of successful cultivators; so that this proportion is a matter of the greatest importance. It is to be feared that in India the proportion of really hard-working cultivators is, owing to various causes, not so large as it should be, and it becomes necessary for us to 
consider these causes briefly, though any elaborate analysis of the foundations of national character would be out of place here.

The factors in the formation of national character are usually divided into three groups, viz.:-

1. Race.

2. Physical environment, including climate, soil, water facilities, etc. To this group may be added the presence or absence of widespread and debilitating diseases such as malaria, hook-worm, guinea-worm, etc. No doubt such diseases are susceptible of prevention and cure at the hand of man, and are not quite of the same class as the factor of climate which is not susceptible of material modification by such means; but for practical convenience it is desirable to include them in this group, since the effect of their operation over centuries is similar to that of the climate.

3. Institutions, including religion, education, government, and the many and diverse social customs which surround us.

In estimating the part which any one of these groups or factors plays in the moulding of national character, the difficulty is that when instituting a comparison between the peoples of various countries with a view to consider how much weight must be attached to any one factor, it will usually be found that there are more variants than one as between any two countries. Supposing, for instance, the problem is how far race is accountable for the difference of 


\section{FACTORS OF NATIONAL CHARACTER 155}

civilisation found amongst Europeans and Negroes, respectively, it will be found that not only does the race of men vary between Europe and Central Africa, but the climate and institutions also vary largely between the two continents, so that it becomes difficult to allot to any one factor its due share in the variation between the two civilisations. We know, however, of what enormous importance race is in the vegetable world and amongst the lower animals, and it is only reasonable to assign to racial inheritance a position of importance in the case of man; indeed many scientific writers attach the greatest importance to it. In some countries where large movements of population have taken place in comparatively modern times, history may give us some clue as to the characteristics of the various elements of the population. Mr. Theodore Roosevelt makes the following claim for the United States of America: "The first colonists to our shores were pioneers who pushed westwards into the wilderness and laid the foundation for new commonwealths. They were men of hope and expectation, of enterprise and energy; for the men of dull content or more dull despair had no part in the great movement into and across the new world. Our country has been populated by pioneers, and therefore it has more energy, more enterprise, more expansive power than any other in the wide world." Similarly it is claimed for England that its racial inheritance from the vigorous races of Angles, Saxons, Danes and Normans was good, and was at a later date fortified 
by the emigration into England of Flemings, French Huguenots and others who had the courage and resolution to leave their own country and to migrate to England rather than submit to oppression.

The existence of two distinct races in the United States of America, the White and the Negro populations, working side by side in identical climates and under similar institutions, offers an opportunity to estimate by actual statistics the variation in efficiency due to race, while if we make a cross division between northern and southern States the variation due to climate may be computed in the case of each race. The census of the United States of America for 1910 gives the following index figures showing the relative efficiency of White and Negro farmers in the North and South, respectively, the figures representing in each case the average of what the members of each group actually produce in the year-

$\begin{array}{llll}\text { Northern Whites . } & \text {. } & 100 \text { per cent. } \\ \text { Southern Whites . } & \text {. } & \text {. } & 51 \text {, } \\ \text { Northern Negroes } & . & . & 49 \text {, } \\ \text { Southern Negroes } & \text {. } & \text {. } & 34 \text {, }\end{array}$

Taking these figures at their face value the comparison is very instructive. Apparently the White farmer working in the northern States produces twice as much as either the White farmer in the southern States or the Negro farmer in the northern States, and three times as much as the Negro farmer in the southern States. If this is so it is clear that the 
influence of both race and climate is very great, and that the effect of each on production is very similar in the case quoted.

It is not proposed to attempt any analysis of the ingredients of the Indian population with a view to estimate their efficiency values, but it must be clear to the most casual observer that there is a great difference between the characteristics of the various classes which make up the population. Not only are the members of the various castes quite distinct racially, but the specialisation in occupation brought about by caste observances has had a marked influence on them. The aptitude of the Brahman for intellectual work, of the Bania for mercantile business, and of the Kunbi for agriculture are well known, while the disinclination of the Bhil to any permanent occupation involving hard work and discipline is generally recognised. It would be difficult to find in any one country a permanent population which presents more distinctions of race, or between any two countries populations whose mental outlook differs more than does that of (let us say) the Brahman and the Bhil. Yet in spite of the rigid racial cleavage, in spite of the specialisation in occupation which results from caste customs, it is quite possible to find keen and industrious cultivators both amongst Brahmans and amongst Bhils, and it is only by taking averages that we can say that under identical conditions one race is more efficient in agriculture than another, as can be said with confidence of the old-fashioned, working Patidars 
of Gujarat, as compared with the Koli cultivators of the same locality.

The effect of climate on the energy of workers must be recognised in some degree by all, but has been worked out in much detail for the varied climates of the United States of America by Professor Huntingdon. ${ }^{*}$ From an interesting series of records of work done under varying climatic conditions he has deduced that the important climatic factors, so far as they affect human energy, are the mean temperature from month to month, the amount of change from one day to another and the relative humidity. The optimum temperature for factory work is a daily mean of $60^{\circ}$ for people of North European stock and $65^{\circ}$ for people of South European stock. In the case of mental work a daily mean of about $40^{\circ}$ is the best. The best climate for physical and mental work combined is one in which the daily mean never falls below $38^{\circ}$ or rises above $65^{\circ}$. Marked seasonal changes are beneficial provided that they are not too violent. As regards humidity, with an average temperature of $50^{\circ}$ the best work is done with a relative humidity of 75 per cent., and with an average temperature of $65^{\circ}$ to $70^{\circ}$ a relative humidity of about 60 per cent. is the best, while at higher temperatures a lower humidity percentage is desirable. The amount of change in the weather and temperature from one day to another has a great influence on human energy. Such changes depend

* "Climate and Civilisation," by Ellsworth Huntingdon (Yale University Press). 
largely on cyclonic storms, and the fact that a great storm belt circles round the North Pole, taking in its course parts of North America, England, North France and the Baltic provinces of Germany gives a great advantage to those countries, apart from the advantage which they enjoy in the matter of temperature. Uniformity of climate, even when the temperature is suitable, has a distinctly deadening effect.

Professor Huntingdon gives detailed figures regarding the effect of climate on factory production. In New England production is highest in the stimulating month of November and is denoted by the index figure of 100 . The heat of July reduces production to 94, and the cold of January reduces it below 90 . In the warmer climate of Florida, on the other hand, the maximum efficiency is obtained during the winter months of November to March. The effect of humidity and of sudden changes in the weather due to storms can be measured in the same way, though with less accuracy, and there can be no doubt that the total influence of the various climatic factors is very great; indeed the conclusion of the author is that the degree of human energy that is found or can be expected in any country, is largely governed by the climate of that country, estimated in terms of the factors mentioned above. On this basis he places India low in the list of countries graded according to the climatic advantages which they enjoy, and expresses the opinion that if the influence of climate were fully appreciated immense seasonal movements of the 
populations of tropical countries would take place, and advocates a great development of migration to hill stations for all brain workers. In his concluding remarks he says: "In tropical countries we may perhaps expect that some day millions of people will not only move to other climates during part of each year, but that many will move back and forth from the lowlands to the highlands every few days. Their work may be arranged so that they can spend two or three days a week in the highlands and the rest in the lowlands."

The influence of climate, however, does not end with its direct effect on human energy, as mentioned above; for it often has indirect effects which are of a far-reaching nature. In India we have a purely seasonal rainfall, and as a result of this the cultivators have for the most part been accustomed to periods of enforced idleness, to conditions of intermittent labour ; and there can be little doubt that irregularity of labour produces bad results, including a condition of apathy and helplessness, which, being transmitted through centuries, acquires the rigidity of a race characteristic.

Turning now to the third group of factors included under the heading "institutions," it would be impossible to deal with such matters in detail. without traversing the whole range of Social Science, and it is not proposed to consider the effects of religion, education or governmental organisation. A wellknown writer on Social Science says: "We have a law of civilisation which has all the force of a law of nature, so uniform is its action; namely, that a 
civilisation or state of society invariably conforms to the religion with which it is associated. The amount of civilisation achieved is, in fact, the amount of progress permitted by the religion, which, in most cases, sets such limits to further progress as cannot be passed unless the religion be first abandoned." Others again make similar claims regarding the supreme importance of education, the system of government and social organisation. There can be no doubt about the influence of all these matters in the formation of national character, but all that it is possible to do here is to call attention to the fact that there exist in India certain laws and customs which operate directly against agricultural progress. Some of these have already been mentioned, such as the law of inheritance in the case of land, the religious obligations towards cattle, and the caste objections to the use of night-soil as manure. Others might be instanced such as religious objections of some classes to take the life of animals and insects which damage crops in the field, and the obligation even to take active measures to preserve the life of weevils which ruin the grain in the storehouse. From a more general point of view also we cannot omit a consideration of the fact that in the Hindu system the joint family and not the individual is the unit. Within the joint family there is complete community of interests and property. The members of the family are assured of maintenance from the family funds not only for themselves but for as many children as they choose to 
bring into the world. No doubt many moral and social advantages can be and are claimed for this arrangement, but it is a question whether they are not bought at too high a price, since, from the economic point of view, the joint family has the disadvantages inherent in any communistic system. In such a system the individual is little affected by the incentive of personal ambition or the spur of dire necessity. Professor Mukerjee,* after claiming many advantages for the institution of the joint Hindu family, admits that on the economic side the system has grave defects, and remarks with regard to it: "New investments of capital are disliked. The system discourages individual initiative, and consequently there is a loss of personal energy. The stimulus to individual exertion not being very great progress is difficult."

We have now considered as far as possible all the causes which do or conceivably may reduce the standard of energy of the Indian cultivators, and the process is, of necessity, a depressing one. There are many obstacles to progress, but some of them, at any rate, may be surmounted when once their importance is recognised; and there are grounds for definite optimism in the fact that in all tracts there can be found some cultivators who work hard and continuously throughout the year, and whose industry will compare favourably with that of the farmer in

* "The Foundations of Indian Economics," Chap. III., by Radhakamal Mukerjee (Longmans, 1916), 
any country. Anyone who will attempt to analyse the circumstances which call into operation the productive energy of this select band will find ready to hand the materials for a most instructive study. Further, a class of men has come in to existence during recent years who make a practice of hiring semiderelict or half-cultivated land for a period of ten years or so, and working it for all it is worth. They usually select a tract where either rainfall or irrigation facilities are good, and where profitable commercial crops can be grown. Such cases are nowadays numerous in the cotton and sugar-cane tracts, and the men in question frequently show much energy, technical skill and business ability. They usually make good profits, often teach their neighbours a good deal that they did not know before, and are quite ready to shift from one locality to another when they can see good prospects in doing so.

There are, therefore, individuals who manage to avoid or surmount the obstacles to progress which we have considered in this chapter. It must be the object of any considered agricultural policy to enable others to do the same, and so to call into activity potential energy which is now latent, and to liberate productive forces which are now repressed. Such a policy will be considered in the next chapter; but before concluding this chapter it may be instructive to cite a well-authenticated case where the standard of productivity and material welfare were greatly raised in a short period amongst large bodies of 
Indian agricultural labourers. The case referred to is the case of the indentured Indian labourers working in Trinidad, Jamaica, British Guiana and Fiji.

The condition of the Indians in these colonies was inquired into in 1913 by special commissioners who submitted a detailed ${ }^{*}$ report on the subject. As regards the material change in the welfare of the Indian emigrants the following statement from the report may be quoted as follows: "The great majority of emigrants exchanged grinding poverty with practically no hope of betterment for a condition varying from simple but secure comfort to solid prosperity. Emigrants live under very much better conditions than their relations in India, and have had opportunities for prospering which exceeded their wildest dreams." The evidence of the material prosperity of these Indians is clear from the figures quoted for Trinidad, where in ten years Indians had bought land worth $£ 72,000$, where the annual deposits of Indians in the Government savings bank were $£ 80,000$, and the annual remittances of Indians to India $£ 3000$. It is further recorded that after the period of indentured labour is finished the majority of these emigrants acquire from 10 to 20 acres of rice land and live in considerable comfort, while some become rich and acquire incomes of $£ 500, £ 1000$ and even $£ 2000$ a year. This constitutes a somewhat

* "Report on the Condition of Indian Immigrants," etc., by J. McNeill and Chimman Lal (Government Central Press, Simla, 1914). 
remarkable change in the position of men recruited from the poorest classes in the congested districts of the United Provinces and Bihar, with populations of 700 to 900 to the square mile, whose prospects at the time were practically bounded by a daily wage of 2 annas.

As regards the change in the standard of efficiency of these emigrants, their history on arrival in the colony is interesting. On arrival it is found that the labour of half to three-quarters of them is useless, as they are suffering from hook-worm (ankylostomiasis), the debilitating effects of which are well known, and it is not until they have spent some time in hospital and got cured of this, that they can be put to work at all. When put to work on the piece-work system current in these colonies, it is found that in the first year even industrious men earn from 10 to 15 per cent. less than the older hands, not because they are unaccustomed to agricultural labour, but because they have no experience of working for 5 or $5 \frac{1}{2}$ days a week, for 7 hours a day, at work which requires constant muscular effort. They have been accustomed to long hours at a slow pace with irregular tasks. Even after the first year of discipline some 10 to 20 per cent. of the emigrants would be glad to limit their work to 3 or 4 days a week, since they can live comfortably on the pay that that amount of labour would bring in; but the rules of indenture forbid this. From an early date an emigrant can easily save 2 s. a week, and as his efficiency increases 
he can save two or three times this amount. Finally, when his period of indenture is finished and he starts working for himself his efficiency increases by an amount which is variously estimated at 25 and 50 per cent. In effecting this change the factors of race and climate had no part; for the men were Indians of the poorest classes, and the climate of the countries to which they emigrated was a tropical climate.

The change that occurred was a change of institutions, and from the group of influences we may eliminate the factors of religion, education and government, for no change in these matters affected the indentured Indian emigrants. What happened was this. Upon arrival in the colony the emigrant came into contact for the first time in his life with an organised and capitalised industry which supplied him with permanent work at a reasonable wage, and incidentally with effective medical assistance. But this would not have been of much use to him unless he had been able to increase the efficiency of his labour so as to take advantage of this opportunity. The road to increased efficiency was opened to him when he escaped from the social and economic regulations and restrictions of family, caste and village organisations. The mill-stone of family obligations, that weighs down so many men from their earliest years, as a result of the obligation of early marriage, was removed. The caste rules which assign or prohibit particular work and particular methods of work to each man were no longer 
binding. He found himself a free economic unit with work ready to hand and every incentive to undertake it to the extent of his capacity. In these circumstances he learned discipline and adopted new standards of labour. Last, but not least, the fact that land could be purchased in suitable holdings afforded a good incentive to ambition and to thrift, and an excellent investment for his capital and for his labour, when the period of indentured labour was completed. 


\section{CHAPTER IX.}

AN AGRICULTURAL POLICY FOR WESTERN INDIA.

We have now considered in detail the conditions under which agricultural progress takes place, and analysed both the direct causes from which increased production results, and the more remote causes through the operation of which progress becomes possible. When it is found in any country that much larger crops are being produced than was formerly the case, the immediate cause will probably be traced to the increased use of manure, to better implements, or to the adoption of more profitable lines of production; but the question will still remain to be answered as to how the organisation of the farmers was improved, how the requisite capital and intelligence were attracted to the industry, how the productive energies of the people were stimulated to the extent necessary for such a change. Examples have been given of the methods by which rapid progress was achieved in other countries, and it has been shown that while agricultural progress can be claimed in Western India, the movement is restricted and the pace is slow. Finally the probable causes of this comparative stagnation have been suggested. It now remains to 
consider whether it is possible to formulate a forward policy calculated to secure general agricultural progress at a more rapid rate.

Before, however, we attempt this task it is essential to consider whether India wishes for agricultural progress, as denoted by enhanced production resulting in the greater material prosperity of the peasantry; and, if so, what price she is prepared to pay for it. Now, there can be no doubt that amongst the people in general the desire for such progress is not so strong in India as in many other countries. Speaking of rural India Professor Mukerjee says: "There is no desire for a better, more comfortable living, both amongst the cultivators as well as amongst the artisans. The village communities are the most complete and the most contented in the world. Within their self-sufficing confines, trade is no vulgar source of profit for which men scheme and strive, but a calling, often a holy calling, handed down from father to son through generations, each with its own unchanging ideals, its zealously guarded crafts." This is, no doubt, a fairly correct estimate of the typical attitude of many Indian cultivators, though it hardly agrees with some of the opinions expressed in the last chapter; and it is only in the present time that any marked change of attitude is observable. This has led many people to question the desirability of schemes put forward for the material advancement of the peasantry. With reference to some such schemes, a former Governor of Bombay remarked not 
many years ago: "So long as the raiyat has sufficient to eat, and is in a position to borrow for weddings, funerals and other festivals, he is perfectly contented and does not want to be improved. Perhaps it is wise of the raiyat, in one sense, to be happy and contented, because it is well known that western civilisation does not necessarily bring with it a spirit of content." There are others who protest passionately against any attempt to interfere with the existing social system and organisation of the Hindus, or to excite new desires and ambitions calculated to interfere with the spirit of placid contentment amongst the cultivators. This attitude is admirably set forth by Sir G. Birdwood in the collection of some of his last writings, published in 1915, under the title of "Sva". They are the views of a fervent admirer of Hindu institutions, and probably voice a large body of opinion in India. He says: "The social aspects of a Deccan village are as of a large family, living together that united life of contentment in moderation which is the perfection of human felicity. What we call prosperity exists only in figures, and has no place in the personal experience of the vast masses making up the population of the so-called progressive nations of the west." "Happy India, where all men may still possess themselves in natural sufficiency and contentment." Referring to attempts to improve Indian agriculture by scientific means, he states: "We are answerable for the happiness of the people of India, as distinguished from the "progress 
and prosperity ' of their country, or in other words its scientific exploitation." He asserts that it would be impossible to introduce the farming methods and appliances of other countries "without involving the destruction of the beneficial, co-operative, rural life whereon the whole system of the civilisation of the Hindus has been immemorially based". Apart from the question of any change in the Hindu system he will not admit that improvement is possible along the ordinary lines on which progress has been secured in other countries. After eulogising the primitive farm implements of the Deccan and declaring them to be preferable to the modern appliances of other countries, he claims for the heavy wooden plough a "perfect adaptation to the surrounding conditions of the land, life and labour in the Maharashtra". He describes the black soil of the Deccan as " the charmed treasure that assures the fortune, the felicity and the unfailing fame of Indian agriculture," and states that, for ordinary field cultivation, it needs no other manuring than that which it receives from the open hand of nature. As regards the cultivator himself he refers to "the wonderful way in which the Maratha raiyat has adapted himself to his surrounding conditions of soil and climate, and gradually secured his economic mastery over them ".

Now if this idyllic picture be accepted of the Deccan cultivator living in the perfection of human felicity after securing the economic mastery over his environment, it is obvious that there is no ground for putting 
forward any active agricultural policy involving a departure from the present state of affairs. But unfortunately this picture hardly agrees with the wellknown facts regarding the poverty of the peasantry, their low standard of living and the inevitable distress that follows a failure of the rainfall, such as we have learned to expect every few years in the Deccan. This outstanding fact of the poverty of the peasant, and all the ills that result from it, has long been the subject of comment of numerous writers; and critics of British rule in India have not been slow to blame the Government for not inaugurating an active, forward policy to improve the economic condition of the masses. As an example of another view of the Indian peasant the following picture* of Indian village life as seen by H.H. The Aga Khan may be quoted: "The ill-clad villagers, men, women and children, thin and weakly, and made old beyond their years by a life of underfeeding and over-work, have been astir before daybreak and have partaken of a scanty meal, consisting of some kind or other of cold porridge, of course without sugar or milk. With bare and hardened feet they reach their fields, and immediately begin to furrow the soil with their lean cattle of a poor and hybrid breed, usually sterile and milkless. A short rest at midday and a handful of dried corn or beans for food, is followed by a continuance till dusk of the

* "India in Transition," by H.H. The Aga Khan (Lee Warner, 1918). 
same laborious scratching of the soil. Then the weary way homeward in the chilly evening, every member of the family shaking with malaria or fatigue. A drink of water, probably contaminated, the munching of a piece of hard black or green chaupati, a little gossip round the pipal tree, and then the day ends with heavy unrefreshing sleep in dwellings so insanitary that no decent European farmer would house his cattle in them. I know of only one other scene of this kind, drawn on a large scale canvas, equally saddening. It is that of the average Great-Russian village before the war, on any day of the winter there. You would see every man, woman and child in the village hopelessly drunk." This conception of the condition of the Indian peasant leads H.H. The Aga Khan to put forward an urgent plea for a vigorous policy calculated to stimulate the ambitions and energies of the cultivators, and to induce them to double their outturn by more intensive cultivation conducted by up-to-date methods and with modern appliances.

Now it would hardly be possible to find two pictures of the Indian peasantry more dissimilar than those just quoted, the one depicting existing rural conditions as the height of human happiness, and the other as touching the depths of human misery, the one passionately deprecating change, the other earnestly calling for it. The remarkable thing is that these extreme views are not peculiar to a few enthusiasts, but are held by large bodies of the educated classes. 


\section{POLICY FOR WESTERN INDIA}

On the one hand there is a party which advocates a return to primitive simplicity, the abandonment of western learning, the disuse of machinery and the cultivation of asceticism to the exclusion of all desire for material advancement. On the other hand the Indian National Congress has for years past demanded a vigorous agricultural and industrial policy. It is easy to say that this cleavage of ideals denotes the gulf fixed between the mental attitude of the East and that of the West. This, no doubt, is true up to a certain point ; but it is not owing to a curious coincidence that, in the two views of Indian village life quoted above, it is an Englishman who advocates the eastern view and an Indian who puts forward the western view. The Government of India, composed of British officials, while recognising the need for material progress, have tended to take up the attitude that it is not desirable to urge the millions of India at a rapid pace along unfamiliar paths or into developments contrary to their traditions and their inclinations. Indeed, this policy has in some quarters incurred the charge of excessive political caution. It is probable, however, that in the minds of most educated Indians the threads of eastern and of western ideals are closely intertwined. These are the men who will mould the future destinies of India, and it is for them to say how far the country desires material progress and how far it is prepared to pay the price which is necessary to secure it. Unless material progress is desired it is unlikely that it will take place ; 
but the desire for such progress is not sufticient. Its price must be paid in labour, efficiency, discipline, enterprise and energy. Idealists have drawn glowing pictures of a regenerated India in which the typically Hindu organisations of the joint family, the caste system and the village community have been strengthened and amplified. The communal family is to be the unit, while the caste organisation controls production, and the village community co-ordinates the local industries for the common good. Above these institutions there is to be an actively paternal Government which sees that every labourer has a plot of land, arranges that manufacturing industry shall be decentralised, that decent houses shall be provided for all, and cottage industries made attractive by the provision of electrical power to work them. In this way work is to be made a pleasure, life is to be made beautiful and noble. Such schemes are sometimes called Indian Economics, and, no doubt, are very attractive, though it is difficult to see how, in such an organisation, there could be any incentive to strenuous work, any opening for individual initiative or enterprise. It is not easy to understand how such conditions could be brought into existence, but assuming that this ideal were to become a reality, the result would be stagnation. For the purpose of considering some definite lines of agricultural policy it is proposed to assume that material progress is desired, but that the country is not prepared for any violent social and economic revolution such as that 
which has taken place in Japan during the past generation. Such an assumption is probably not at variance with the opinions of most educated Indians, though views of sober moderation seldom find expression in the war-cries and catchwords of political parties.

Before considering any future policy it will be desirable to take a brief review of the agricultural policy of the past century. So far as western India is concerned three characteristics of early British policy with regard to the land may be noted. In the first place no attempt was made to develop agriculture by assigning blocks of land to individuals for exploitation by foreign capital and foreign enterprise. In some parts of India where there were large areas of unreclaimed waste, such as Assam and parts of the United Provinces, grants of land were made to English zemindars during the early part of the last century for purposes of reclamation; but this practice was never a plank in the policy of the British Government in India in the same sense that it formerly was of the Dutch in Java and still is of the Japanese in Formosa. In Bihar and Lower Bengal also Englishmen acquired rights over considerable areas of land by private treaty with the zemindars for the development of the indigo business. They erected factories and arranged to grow and handle the crop on commercial lines. In the year 1877 it was estimated that in the single district of Tirhut the annual outlay of the indigo factories amounted to Rs.30 lakhs, apart from capital 
expenditure. There can be no doubt that the indigo industry received a great stimulus from the English capital and enterprise that were attracted to it. But the system had its drawbacks. Disputes were common between the European factories on the one hand, and the neighbouring zemindars and the labourers, on the other hand. These disputes caused difficulties to the administration in many cases, and in the Nadiya district in 1860 they culminated in serious riots which greatly crippled the indigo business. Government were at the time severely criticised for not vigorously supporting these European zemindars in the interests of the economic development of the country. Still on general principles it was certainly a sound policy on the part of the early British administrators in India to sacrifice a short cut to economic progress, which could hardly have given a sound foundation to normal development, would probably have created serious administrative difficulties, and would certainly have caused permanent dissatisfaction to some classes of the Indian community. The question of equity in connection with a general policy of this nature has not been mentioned, but it may be of interest to quote the opinion* of a professor of the Yale University expressed in a very impartial comparison of the land policy adopted by the Dutch in Java and by the British in India, respectively: "There is," he says, "this essential difference that

* "The Dutch in Java," by Clive Day (Macmillan, 1904). 


\section{POLICY FOR WESTERN INDIA}

the British Government has never made itself responsible for the evils by encouraging the system that gave rise to them, and if it sinned it was by omission. The British Government faced the right way, whatever were its weaknesses; the Dutch Government was in itself a wrong."

The second characteristic of the British land policy in India was that full liberty was left to the landholder to treat the land in any way that he thought fit, and no compulsion was placed upon him to grow particular crops, to adopt particular methods or to sell his produce to particular people. The system of "forced cultures" in Java has already been referred to (p. 37) as an extreme example of State interference in agricultural matters intended to secure the most efficient methods and the largest production. There were formerly* many who urged the British Government to adopt a similar system in India in order to achieve rapid material progress; but no departure of this nature was made. The matter is one of more than historical interest, since suggestions are still frequently made that Government should exercise control over the system of cultivation.

'The third feature of the land policy in western India is that the general principles of land tenure and assessment found in existence were adopted and reduced to a definite system. Perhaps the two points in this connection that have been most criticised are

* “Java ; or How to Manage a Colony,” by J. W. B. Money (1861). 
the pitch of the assessment and its liability to revision every thirty years. So far as these points are concerned, the situation has been fully discussed elsewhere $^{*}$ It is certainly essential that the pitch of the assessment shall be based on a consideration of what the cultivator can well afford to pay, and that the enhanced demands of the periodical revision settlements shall be tempered by moderation; but the public revenues have to be raised, and the present system is probably the most equitable method of raising them. There is no valid ground for believing that it depresses production or discourages permanent improvements to the land. Another matter which has been much discussed is the power given to the land-holder of alienating his land. It is doubtful how far he had such power under the rule of the Peshwas; but in practice, at any rate, he seldom exercised it. It was part of a deliberate policy to make the transfer of land easy; and Wingate, the author of this policy, in 1836 expressed himself thus: "The most effective means at our command for preventing the land becoming the inheritance of a pauper, or at least a poverty-stricken peasantry, is to afford the greatest possible facilities for its conveyance from one party to another; so that when a cultivator becomes impoverished, and by his inability to cultivate properly, deprives the community of the wealth it is capable of producing, the land may get into the hands of some

* "Rural Economy in the Bombay Deccan," Chap. II., by G. Keatinge (Longmans, 1912). 
one better able to turn it to advantage." It must be admitted that this facility for the transfer of land did not produce all the advantages that were expected of it, and led at times to inconvenient consequences. It has in the past been subjected to severe criticism, and has undergone some modifications to meet certain definite difficulties; but as a general principle it still holds the field, and is commonly accepted by those who aim at material progress.

It will be realised from the above that the land policy adopted in the Bombay Presidency was at first a somewhat negative policy of non-intervention. The early British administrators, brought up in the school of Adam Smith, Ricardo, and Arthur Young very soon made up their minds as to the lines on which progress was indicated. "Give the cultivators a definite property in the land," they said, "give them security of tenure, a guarantee that their improvements will not be taxed, and a light, equitable assessment, and, with settled conditions, there will be a great improvement in agriculture and a marked increase in prosperity." The area under cultivation certainly increased by leaps and bounds as a result of this policy, and land values, which had hardly existed before, were created and tended to increase steadily; but progress towards land improvement, intensive cultivation and improved methods was very meagre; indeed the development that attracted most attention in the middle of the last century was the tendency of the land-holders to take advantage of the 
value that their land had acquired to effect land mortgages and to live on their capital. The next action of Government was in the direction of improved communications. The country was covered with a net-work of roads and railways. This has certainly put the farmer in touch with the larger markets of India and with the markets of the world; and as a result he now gets a much better price for his produce than was formerly possible when he had to depend on the local market. This is, of course, an enormous advantage. The next line of improvement was to guard the country against the devastating effects of a failure of rain. A large number of irrigation works were projected for the Deccan, and some were constructed. These works are distinctly beneficial, so far as they go; but for reasons which have been set forth in Chapter IV. their scope has been restricted. and their utility unduly limited. To facilitate land improvement, Government undertook to lend money to cultivators at low rates of interest. This action, too, had a beneficial tendency, but was, of necessity, on a scale too small to have any great or general effect. To enable the farmer to realise his credit and to secure at reasonable rates of interest the capital essential for his requirements, the co-operative credit organisation was started, and has subsequently expanded into a general co-operative movement. This movement has had a remarkable success, and is rapidly becoming a real power for good in the land, but it will be some time before its full effects are felt. 
Finally, to improve the technique of farming and to assist the farmers to adopt the most profitable system and methods of agriculture, the Agricultural and Veterinary Departments were organised and developed to undertake scientific investigation and instruction, to demonstrate improved methods that have stood the test of local experience, and to help the cultivators to adopt them. It has been shown in Chapter V. that here too substantial progress has been achieved, though not perhaps of so sensational or spectacular a nature as some people expect.

In spite of all this, however, the poverty of the peasant remains the outstanding feature of the situation, large areas of undeveloped and derelict land meet the eye on all sides, and labour is found standing idle and running to waste in every village for a large part of the year. Are there, then, some causes which obstruct progress, which work continuously but imperceptibly to counteract for the general body of agriculturists, the progress which is secured with so much labour in certain directions and for a limited number of individuals? It now seems clear that the early British administrators were over-sanguine. in expecting that if they cleared the way to progress, so far as Government institutions were concerned, the economic motive-power would be found by an invertebrate body of backward agriculturists. Even as regards the more active policy of recent times it is often the disheartening experience of members of the engineering and agricultural depart- 
ments that their efforts are severely handicapped and the results of their labours heavily discounted by the economic obstacles which stand in their way. Some people appear to think that these obstacles are insurmountable. Sir Henry Cotton * writes as follows : "Our attempts to teach the natives of India agriculture are based upon a forgetfulness of the essential elements of the case. The native cultivators of India are too poor to be able to adopt the scientific improvements which English experience suggests. They are told to plough deeper, to do more than scratch the soil. But it is forgotten that the cattle with which they plough are incapable of deep ploughing. We tell them to enrich their fields with manure, and that the produce of the land would be augmented by its use. No doubt it would. The ryots do utilise manure as much as they possibly can, in the way of simple forms of manure, such as cow-dung-which, is, however, also an extremely useful article to the poor cultivator as a substitute for fire-wood-but they can no more afford to procure the expensive manures with which we are so familiar than they can afford to plough with elephants." Now there are statements of fact made in this quotation which do not entirely accord with the realities of the situation in western India. But even accepting the facts as stated above, are we to agree with Sir H. Cotton in fearing that the poverty of the people obtrudes as a

* "New India," by Sir Henry Cotton (Kegan Paul, 1907). 
permanent obstacle to improvement? Surely not. The poverty of the people is at least as much the result of their ineffective methods as the cause of them. Even admitting that there is a vicious circle of poverty, inefficiency and stagnation amongst large classes of the peasantry, this vicious circle can be broken in India as it has been broken elsewhere; and the machinery required to do this is being slowly forged by the development of the agricultural and co-operative departments. What then are the economic causes which bar the way to progress?

If the arguments set forth in Chapter IV. and Chapter VIII. have been followed the nature of some of these obstacles will be apprehended. The case may be briefly stated as follows. In farming there are two fundamental units, the farm and the farmer. For agricultural progress it is necessary that the farm should be a fixed and permanent unit, so that it may admit of permanent improvement and adequate development, and that the farmer should be a fluid and movable unit, so that the right men may get to the right places. Speaking generally, we find that in India the exact reverse is the case; that the farm, on the one hand, is subject to a continuous series of economic earthquakes, and that the farmer, on the other hand, is fixed and rooted.

To turn first to the farm. The evil results of excessive subdivision and fragmentation of land have been fully dealt with in Chapter IV. No orderly development, no effective improvement can take 
place in a holding which is the wrong size and shape and which has no stability. The fact that this is true not only in theory but in practice can be verified by anyone who will take the trouble to do so. Not only is the land totally undeveloped, as development is known in other countries, but the idea of progressive development is hardly understood by the land-holders. To develop and improve a permanent 10 or 20 acre farm is an intelligible proposition; but to develop a 10 or 20 acre farm which must in the near future be split up and fragmented is not an intelligible proposition to anyone; and since this is the proposition which confronts the Indian farmer, it is not surprising that he does not consider it seriously.

Now let us turn to the farmer. The farmer owns his small and fluctuating area of land, it may be 15 acres of land in three plots in one generation, and 5 acres in six plots in the next generation. The point is that the farmer is fixed and permanent. His farm may fly into fragments and grow steadily smaller, but, generally speaking, he himself persists, whether he be a good, bad or indifferent farmer. In highly individualistic and competitive countries efficiency is secured largely by the elimination of the unfit, who are squeezed out of the race by keen competition, coupled with a high standard of living. This law is in constant operation in England, and there have been periods of agricultural depression there when unprogressive farmers have been ruined and squeezed out wholesale, while on some kinds of soil it is recognised 
that a bad farmer cannot hope, even in prosperous times, to survive many seasons. In rural India, however, the competition is less keen, the standard of living lower, and the principle of community of goods which characterises the joint family system tides the less effective members over their difficulties, and keeps them in their places to the obstruction of the more effective members of the community. It is by no means contended that there are no good farmers, nor can it be expected anywhere that all farmers will reach a high degree of excellence : all that is suggested is that, owing to the causes mentioned above, the proportion of bad and indifferent farmers is unduly large.

The situation may be summed up thus: The majority of farms are of the wrong size and the wrong shape: they are not permanent units and are not susceptible of orderly and adequate improvement. The majority of farmers are deficient in skill, industry and energy, and balance a low standard of endeavour by a low standard of living.

Is it then desirable that Government should pass a series of legislative enactments to parcel out the land into innumerable economic holdings of standard shape and size, to dictate to the farmer what crops he shall grow and how he shall grow them, to hustle him into greater activity by official interference? It is necessary at this point to state emphatically that no general policy of this nature is suggested. So far as Government is concerned the cultivator has always enjoyed 
a large amount of personal liberty. He appreciates the liberty and would resent its loss. Nor could any permanent basis of progress be laid by such measures; for without economic liberty, enterprise is not possible, and without enterprise progress will not take place. Great emphasis has been laid on the necessity for checking excessive subdivision and fragmentation of the land, and it is shown in Appendix II. what drastic legislation has been taken in some countries to achieve this object. But the measures suggested (Chap. IV. and Appendix III.) as desirable for western India make no suggestion of compulsion. They amount to no more than giving the land-holder a chance of freedom from the operation of laws and customs which impede his progress. Public opinion is not ready for more, and any attempt at this stage to coerce the cultivator along lines contrary to his traditions and inclinations would only serve to defeat its object. In India, as elsewhere, circumstances arise where the interests of individuals must give way to those of the community in order that some great public benefit may be secured. Some such instances have been mentioned. They are the exception not the rule.

Leaving the sphere of Government action we may turn to the domain of social and religious customs. Social reformers in India have much to say regarding the tyranny of caste and the oppressive working of the joint family system, and it has already been indicated that there are many customs of a religious 
nature which impede economic progress. In such matters the Indian farmer is anything but a free agent. It is open to anyone to say that he prefers his religious sentiments to economic progress. This is quite an intelligible proposition. But it must be remembered that many customs which have a religious aspect came into existence in primitive times when they had an economic value. As conditions change the economic advantage of any custom may become an economic disadvantage. When this occurs the custom needs modification. Such changes have been common in other countries. The early Christian church used to teach that it was a sin to take interest on money lent, and at one time no Christian could lend money at interest. It might be an interesting speculation as to how far the industry and commerce of Christian countries could have grown up, had this custom retained its original force. Such changes cannot be thrust on a people by law; they can only be effected by a change in public opinion; and this is likely to take place only when the true economic significance of the facts is recognised.

It now only remains to indicate some definite lines of policy calculated to accelerate agricultural progress. With this object it is proposed to recapitulate briefly twelve points which have already been dealt with in detail.

I. The system of land tenure best suited to western India is that of peasant proprietors; and the only exceptions to this rule which are at present obvious 
are the cases of sugar-cane estates and dairy farms. There are special reasons of public importance why the production of sugar and milk should be encouraged, and it is desirable that Government should take such measures as may be necessary to secure land for substantial companies wishing to start such enterprises and able to command the capital and skill necessary for the purpose, with a view to giving such undertakings a fair chance of making a start.

II. If peasant holdings are to be successful, it is essential that they shall be of a suitable size and shape, and that they shall be permanent units capable of steady development. It is very important, therefore, that steps should be taken to check the continuous tendency towards the subdivision and fragmentation of the land, and to give the land-holders a chance of forming economic holdings with some element of permanence. Such action can be taken only with reference to the state of public opinion on the subject.

III. No attempt should be made to interfere with the freedom of the cultivator to grow such crops as he wishes and in the way that he wishes. Suggestions are frequently made that, in the interests of the consuming public, the export of grain should be regulated, with a view to bringing down the cost of living. If this were done the effect would probably be to make the cultivator grow more cotton. To prevent this it is sometimes proposed that the proportion of any holding that may be sown with cotton should be 
limited. This would, of course, reduce the profits of cultivation. Again, with the idea of making cattle cheaper for the cultivator, it is often proposed to prohibit the export of cattle. This would merely tend to depress the profits of cattle breeding, and the result would be the reverse of what was intended. It is not possible to stimulate agriculture by measures which tend to make one branch after another unprofitable. It is certain that if the organisation of the farmer could be improved some profitable changes in the system of production would result; but the one must be left to follow naturally from the other. In such matters the farmer is, and must always be, the best judge of what pays him best.

IV. Where the market for any kind of produce is ruined by fraudulent practices, legislation may be undertaken with advantage to check such practices. An example of such legislation is given in the proposal made to regulate the movements of cotton.

$\mathrm{V}$. To protect the country against the effects of the recurring failure of rain the programme of irrigation works should be pushed on as fast as possible. The pace has been slow, but could be accelerated, and the value of the irrigation works could be greatly enhanced by the adoption of the policy advocated in the second part of Chapter IV. Apart from the large storage works for irrigation, every effort should be made in the arid tracts to encourage the construction of wells and the pumping of water from rivers where suitable facilities exist. 


\section{THE MACHINERY OF PROGRESS 191}

VI. To improve the organisation, equipment and credit of the cultivators, the co-operative movement should be steadily expanded to the full extent that the requisite organising and managing ability for the purpose can be found. The development of manufacturing industry and commercial enterprise, also, will help in the same direction.

VII. The work of technical research, demonstration and instruction should be steadily expanded with the help of generous financial grants, as the staff necessary to undertake such expansion becomes available.

VIII. The great advantage to the small farmer of living on his farm, and not at a distance of several miles, should be recognised. Cultivators should be encouraged to build houses on their holdings; and when a village site becomes overcrowded, the opportunity should be taken, as far as possible, to create a detached hamlet rather than to enlarge the existing village site.

IX. The advantages to be derived from the various measures mentioned above will be secured through the medium of increased activity on the part of the cultivators. The quality of a man's work depends largely on the circumstances in which he performs it. The cultivator living on a holding of suitable size and shape, well equipped and organised, will work much better than the man who has none of these advantages. Similarly the man who is protected by irrigation facilities against the worst disasters arising 
from failure of rain, and the man who can finance his operations from time to time without being crushed by a heavy rate of interest, will work with the greater energy which arises from confidence.

$\mathrm{X}$. There is a second group of causes which affect the energy and enterprise of the agricultural classes. The family and caste organisations weaken the feeling of individual responsibility and personal initiative which count for so much in the achievement of progress. The general attitude of mind produced by such systems seems to be an easy-going tolerance which aims at no more than protecting the least efficient from disaster and tiding over present difficulties, regardless of the future. This attitude of mind expresses itself in demands for frequent remissions of revenue which the land could well afford to pay if it were properly.worked, in proposals that obligations incurred to the village sovvkar or to the village Co-operative Society need not be enforced, in suggestions that Government should provide free grazing in ordinary times, and in times of scarcity should be responsible for the maintenance of cattle for which the owners hardly attempt to make any adequate provision. It is by no means contended that the solution of the agricultural problems of India can be found in a system conducted on rigid principles of business economy; but the tendency is at present too much in the opposite direction. The result is to bolster up the inefficient, and to sacrifice the hope of the future for the convenience of the present. 


\section{RESTRICTIVE SOCIAL CUSTOMS 193}

XI. There is another set of customs, social and religious, which are directly opposed to economic progress, such as the Hindu attitude towards the whole treatment of cattle, the Jain attitude towards the taking of life, even in the case of injurious animals and insects, the fastidious objections of some classes to the use of night-soil as manure, the social customs which prevent the women of some castes from leaving the seclusion of their houses, and the idea current amongst men of a certain social status that the performance of active field work involves a loss of respectability. The economic losses involved by such customs are enormous, and the more that this fact is realised the sooner will the customs tend to be modified. Any change in such matters must come from the people themselves.

XII. The circumstances which affect progress are many, and need careful watching. They may be physical, economic or technical. To deal with technical matters a number of Provincial Departments of Agriculture have been established in India, which are, no doubt, in a position to keep an eye on the general situation with regard to matters which are not purely technical. It has, however, been found desirable in some countries which are aiming at rapid progress to appoint for every suitable tract a standing Development Commission, whose duty is to inquire into profitable lines of development, see that physical advantages are not wasted, and direct any measures that it may be considered desirable 


\section{POLICY FOR WESTERN INDIA}

to take with a view to secure progress. Standing Development Commissions of this kind have done good work in the United States of America. When the path that leads to progress has once been cleared, it is possible that development might be promoted by some such agency in India.

This concludes the review of agricultural progress that was attempted. The climate of India is not particularly conducive to hard work, and it may be admitted that there are some elements in the Indian population which are lacking in energy, perseverance and discipline. Amongst the mass of Indian cultivators, however, there are large numbers who reach a high standard of diligence and industry when their circumstances and organisation permit them to do so. With the physical conditions and human material available, the possibilities of material progress are large and varied. The pace at which it will take place must depend on how far the bulk of the people desire it and are prepared to pay the price necessary to secure it. With a view to explain the slow rate at which progress has taken place it has been necessary to call attention to all obvious defects in the institutions and customs of the peasantry; but the last thing that is intended is to belittle the skill and industry of the many good cultivators in western India. No one who has worked amongst them can fail to appreciate their admirable and amiable qualities. It is to these men that this book is dedicated. 


\section{APPENDIX I.}

THE EXTENT OF SUBDIVISION AND FRAGMENTATION OF HOLDINGS IN THE BOMBAY PRESIDENCY.

THE extent of subdivision and fragmentation of holdings in the Bombay Presidency differs considerably in the different tracts. It is greatest in the rice lands of the Konkan and Ghat strip of the Deccan, where the conditions of rice cultivation and the value of the rice crop tend towards the existence of small holdings, and where the pressure of the population on the area of rice land, and in particular on the fertile coast strip, accentuates the evils of excessive subdivision and fragmentation.

A.-Konkan and GHat Strip of the Deccan.

Statement of typical cases showing from different points of view the extent to which subdivision and fragmentation have proceeded in the districts of Kanara, Ratnagiri, Kolaba and Thana.

\section{CASE No. I.}

(Survey Nos. 1 to 40 of Uppina Paitan, taluka Kumta, district

$$
\text { Kanara.) }
$$

This area of 52 acres was selected simply because it was a nice compact block of land with excellent natural facilities, which might have sufficed for 3 or 4 rich holdings, or 6 or 8 
196 SUBDIVISION OF HOLDINGS

CASE No. I.

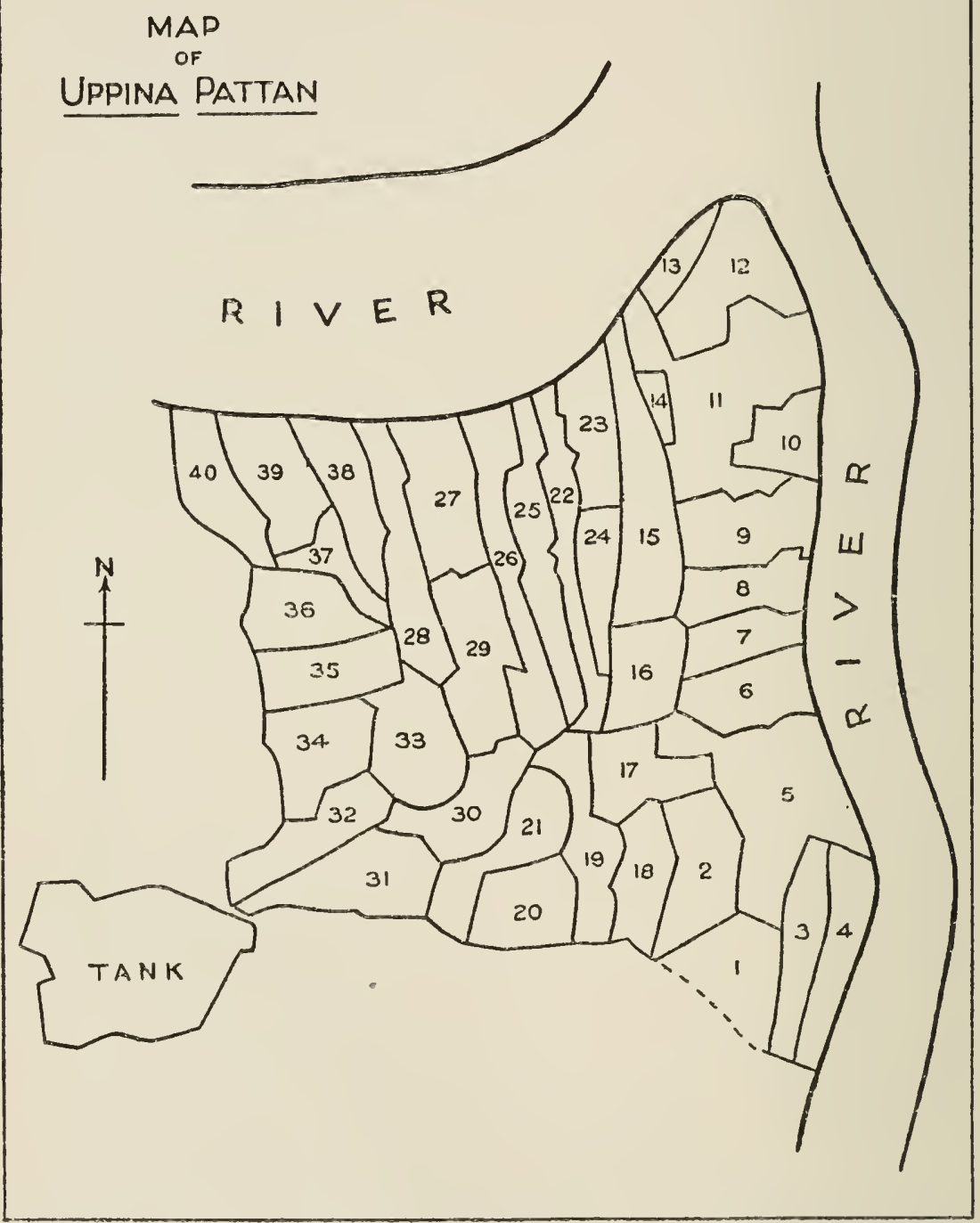




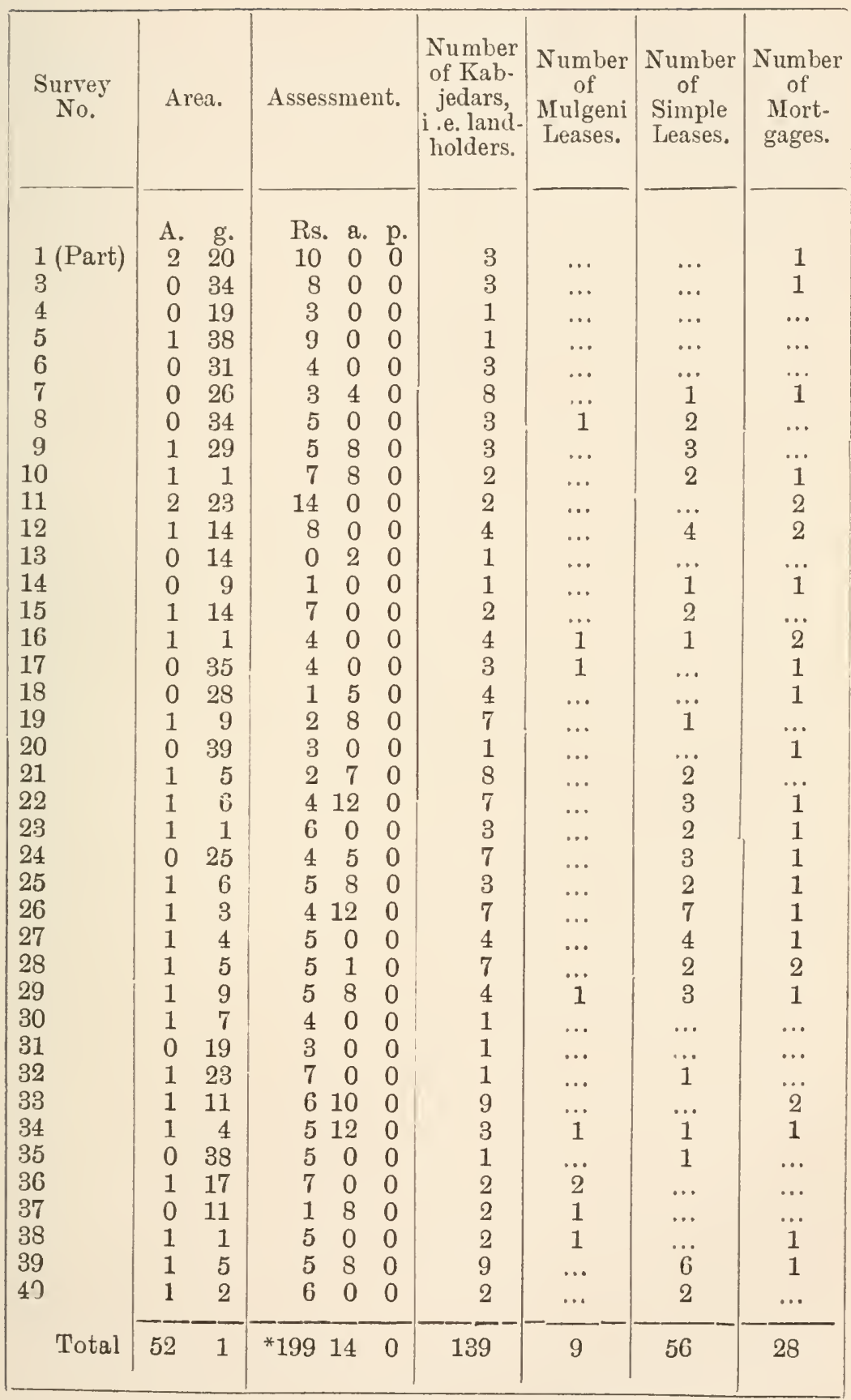




\section{8}

\section{SUBDIVISION OF HOLDINGS}

fair holdings. In point of fact it is divided up into 139 separate plots held by about 50 land-holders. A map of the land and a tabular statement showing areas, number of plots, number of mulgeni (permanent) leases, number of simple leases and number of mortgages are attached.

The number of Kabjedar's (land-holders) entered against each survey number represents the number of separate plots into which the land is divided. The same men, however, own land in several survey numbers, so that the actual number of owners is less, being about 50. In another way, however, the fragmentation is even greater than the figures indicate, e.g. in Survey No. 1 the number of shares shown is 3 ; but in reality the field is divided into 18 plots, each sharer cultivating 6 plots annually, and moving on to another 6 plots the year after, and so on.

The following details regarding two of the survey numbers give a good idea of the fragmentation :-

Survey No. 7, garden land growing cocoanuts :-

Subdivisions-

1. Ganpu Dodda Gunthas.*

2. Ganpu Bira

3. Ganpu Dodda . . . . . . $2 \frac{3}{8}$

4. Ganpu Bira . . . . . . 7

5. Mahabalu Mari . . . . . $1 \frac{7}{8}$

6. Rama Anapa Naik . . . . . $2 \frac{1}{2}$

7. Mahabalu Mari . . . . . 1

8. Shridhar Manjanath Shanbog . . $8 \frac{1}{2}$

Total $\overline{26}$

${ }^{*} 1$ guntha $=\frac{1}{40}$ th acre. 


\section{APPENDIX I}

Survey No. 33, rice land:-

Subdivisions-

1. Mahalaxmi kom Sadashiv Naik . . $3 \frac{1}{4}$

2. Tulsi kom Shiv . . . . . . $4 \frac{3}{4}$

3. Timapa Damgauda . . . . $4 \frac{3}{4}$

4. Mahabalu Mari . . . . . $\quad$. 6

5. Ganpu Dodda . . . . . . $8 \frac{1}{2}$

6. Ganpu Bira . . . . . . 13

7. Ramchander Sababhatta . . . $2 \frac{1}{2}$

8. Dasu Vaikanth Pai and Wasudeo Krishna Pai . . . . . $7 \frac{1}{2}$

9. Kuppa Maragauda . . . . 1

Total 1 acre 11 gunthas.

A cultivator can sometimes lease land contiguous to his own holding, and in this way some temporary unification of the land is effected, though it does not go very far. The following gives a typical case of the area actually cultivated by one of the most substantial cultivators in the village, viz. :-

Ganpu Bira cultivated 12 acres of rice land, of which he owns 3 acres and hires 9 acres: the 12 acres which he cultivates is divided into 21 different plots.

\section{Physical Condition of the Land.}

The whole of the land is rice land except that on the edge of the river a few fields contain a certain number of cocoanut trees which are badly looked after and not irrigated. There is a tank in the jungle close by which, it is stated, formerly provided sufficient irrigation water to grow a second crop of waingan rice (i.e. hot weather rice) or sugar-cane on practically the whole area, to which it was conducted by a channel round the upper contour of the field. The tank is now much silted up and the channel out of order. Rice is grown in the monsoon, and afterwards there is enough water for about 
4 acres of waingan rice and 2 acres of sugar-cane. In the absence of a water channel this water runs down to a low part of the field and is lifted once and in some cases twice on to the sugar-cane land.

It is obvious that the following improvements were needed :-

1. The tank required clearing of silt or to have the bund raised.

2. The water channel needed repair so that the water could be taken to any part of the field by gravity.

3. Some embankments against flood water from the river were needed.

4. The land needed proper fencing against wild animals from the adjoining jungle, which do much damage. Having the river on two sides, it needed fencing on only two sides.

5. The whole needed to be properly laid off into level plots of reasonable size, so as to admit of easy cultivation, instead of being divided into very small and irregular shaped plots, with bands in between, which occupied an excessive amount of space.

On account of the excessive subdivision and fragmentation of the land it is hopeless to contemplate the possibility of any such improvements.

\section{CASE No. II.}

(Survey Nos. 2, 4, 5, 6, 7, 8, 13 and 26 of Shirgaon, taluka Ratnagiri, district Ratnagiri.)

Case No. I. refer's to an area which is held almost entirely by cultivator's. In some parts of the Konkan the bulk of the rice land is in the hands of non-cultivating landlords. Naturally in such cases the holdings tend to be larger, and the fragmentation less, but this case which occurs at Shirgaon, where the Government Farm is situated, gives an instructive example of the way in which such holdings are becoming subdivided and fragmented. The area consists of a block 
CASE No. II.

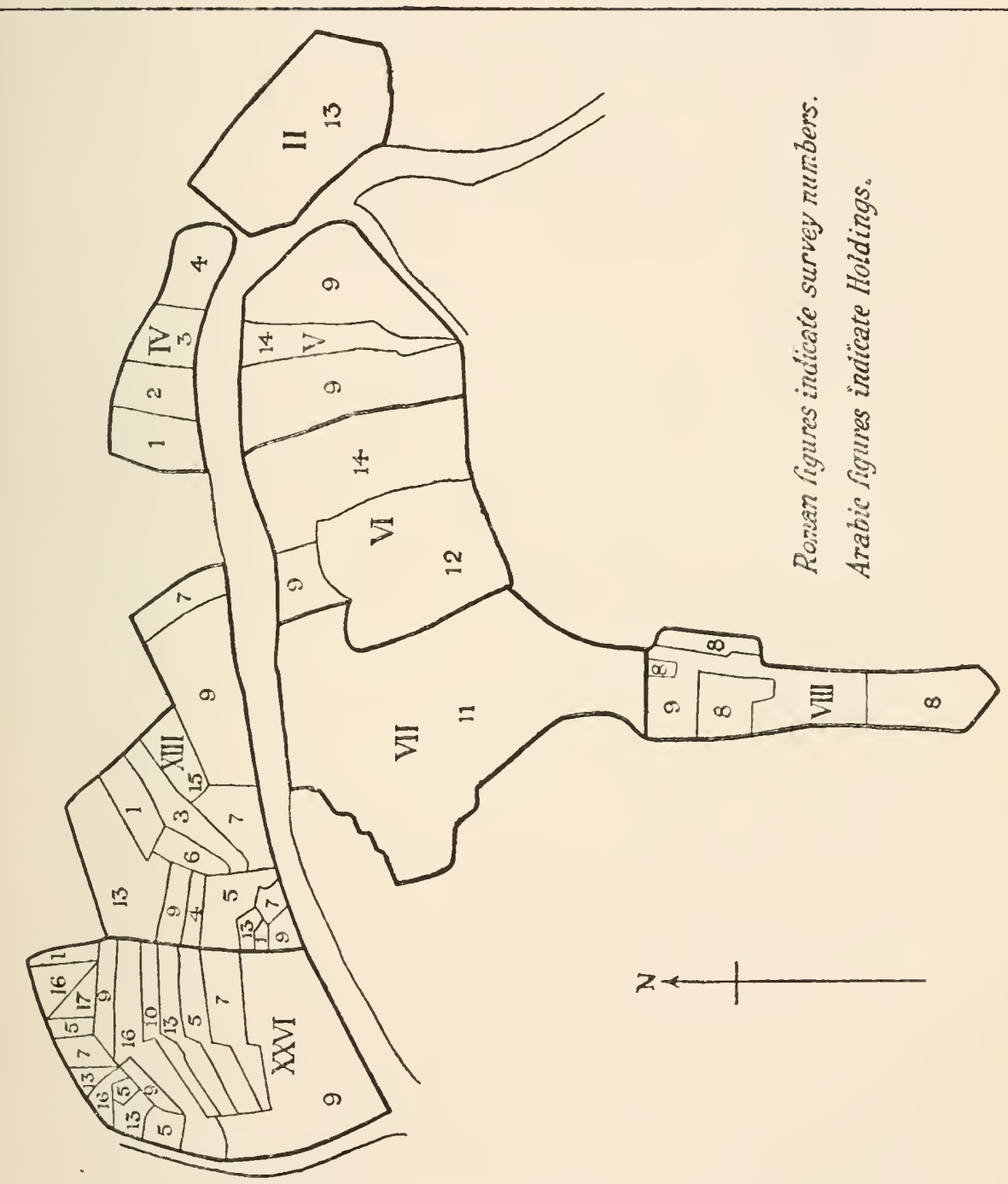


of good rice land. It will be noticed that one holder has a nice block of $6 \frac{1}{2}$ acres of rice land; but most of the holdings are badly split up, as can be seen from the map and statement. This case is intended to indicate merely the extent of fragmentation of this class of holdings.

Block of Rice Land Consisting of 8 Survey Numbers in Shirgaon, Ratnagivi Taluka, and Divided into 17 Separate Holdings.

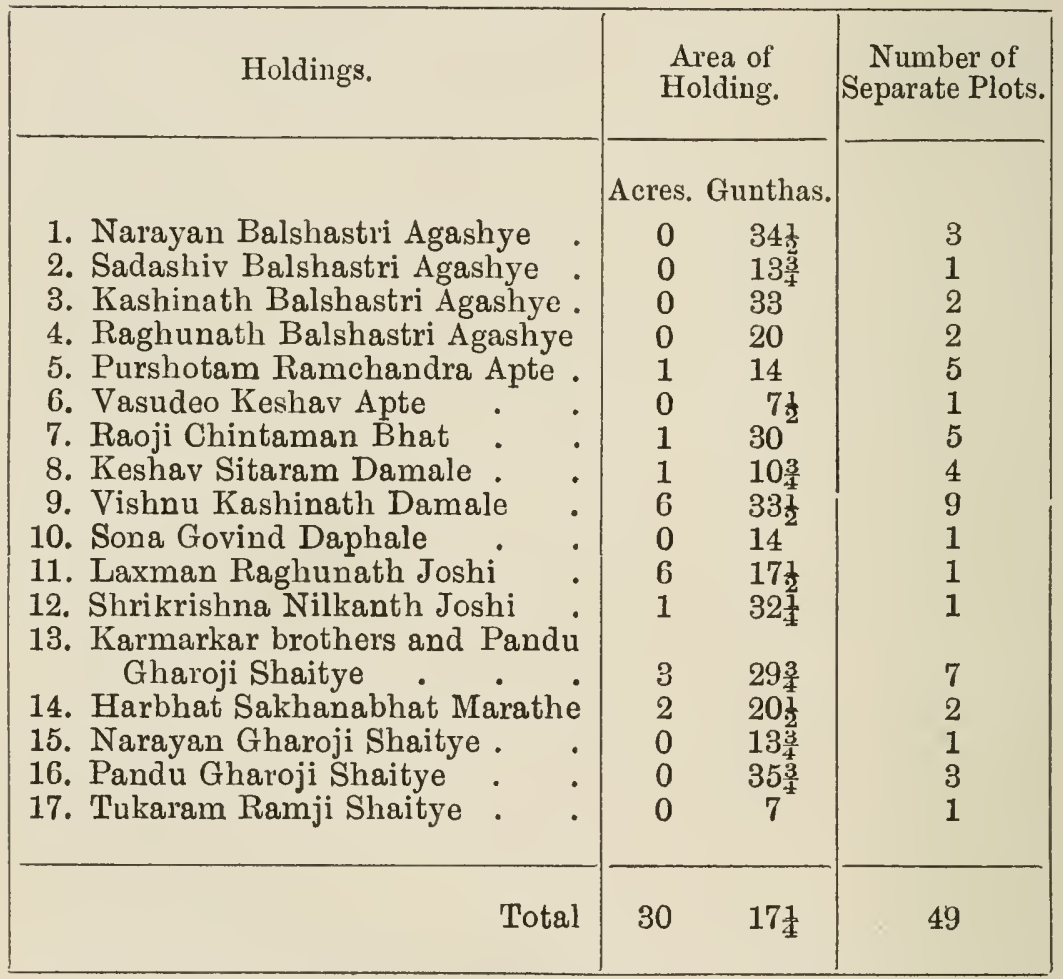

CASE No. III.

The attached map merely indicates the extent of the fragmentation of 3 large holdings in Kane village, taluka Pen, district Kolaba. Holdings Nos. 1 and 3 belong to agriculturists, holding No. 2 to a non-agriculturist. 
CASE No. III.

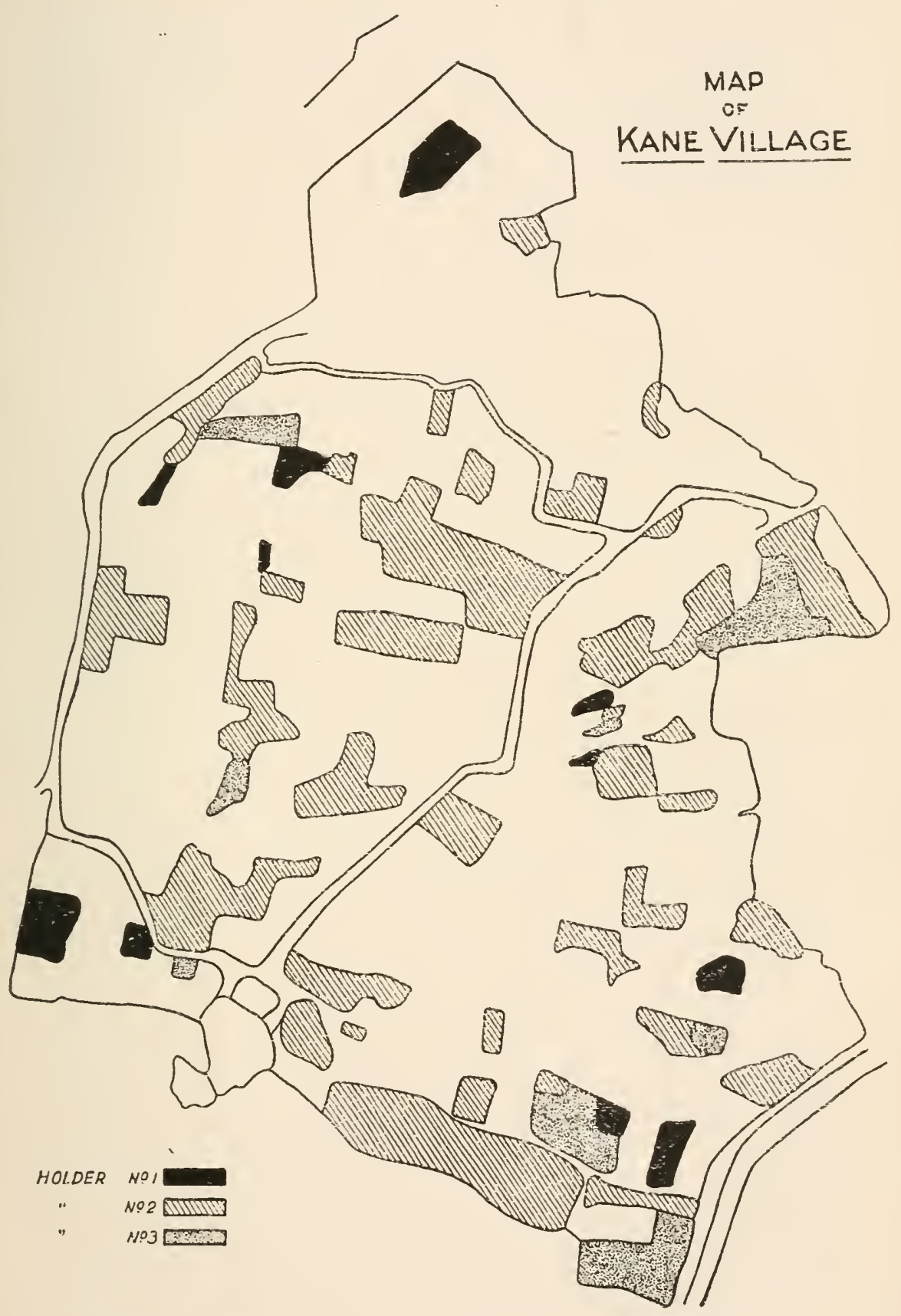


Statement Showing Different Holdings held by three Different Kabjedars in the Village of Kane, Taluka Pen.

\begin{tabular}{|c|c|c|}
\hline No. & Name of Kabjedar. & $\begin{array}{l}\text { Reference to Survey Number on the } \\
\text { Map in which his Holding Exists. }\end{array}$ \\
\hline 1 & Ganoo Chang Patil & $\begin{array}{l}3,5,6,29,31,66,67,74,86,102, \\
105,115 \text { and } 33 .\end{array}$ \\
\hline 2 & Mulchand Gemaji Shet & $\begin{array}{l}8,9,13,14,15,16,21,23,24,27, \\
29,32,34,35,36,38,39,41,42, \\
43,50,55,56,59,61,62,63,64, \\
65,67,68,69,70,72,78,81,82, \\
83,84,85,91,92,96,97,100 \\
102,103,106,109,110,111 \text { and } \\
113 .\end{array}$ \\
\hline 3 & Pavsya Kal Patil. & $\begin{array}{l}2,17,32,61,62,63,67,85,86,102 \\
\text { and } 107 .\end{array}$ \\
\hline
\end{tabular}

CASE No. IV.

The following statement merely indicates the extent of subdivision of holdings in a typical village, showing the holdings of agriculturists and non-agriculturists separately. The village of Nehuli, taluka Alibag, district Kolaba, was selected because practically all the occupied land in the village is rice land, less than 4 acres out of 125 acres being warkas (i.e. dry crop) land. It will be seen that the average size of a holding held by an agriculturist is only $2 \frac{1}{3}$ acres, and by a non-agriculturist $3 \frac{1}{2}$ acres. Amongst 24 agricultural holdings one is large, 3 or 4 fair in size, and the rest very small, 9 being less than one acre. Amongst 19 holdings of non-agriculturists one is large, 5 fair in size, and the rest very small, 8 being less than 1 acre. 


\section{APPENDIX I}

Nehuli Village, Taluka Alibag, district Kolaba.

Agriculturists' holdings.

Non-agriculturists' holdings.

\begin{tabular}{|c|c|c|c|c|c|}
\hline Holding No. & Acres. & Gunthas. & Holding No. & Acres. & Gunthas. \\
\hline 1 & 3 & 33 & 2 & 9 & 6 \\
\hline 7 & 6 & 7 & 3 & 4 & $27 \frac{1}{2}$ \\
\hline 8 & 4 & 37 & 4 & 7 & $20 \frac{1}{2}$ \\
\hline 9 & 2 & 18 & 5 & 2 & $33^{2}$ \\
\hline 10 & 3 & 28 & 6 & 0 & $34 \frac{1}{2}$ \\
\hline 11 & 2 & 4 & 14 & 2 & $28^{2}$ \\
\hline 12 & 1 & 34 & 17 & 0 & 27 \\
\hline 13 & 0 & $2 \frac{1}{2}$ & 18 & 1 & 6 \\
\hline 15 & 18 & $17^{2}$ & 19 & 0 & 39 \\
\hline 16 & 2 & 5 & 20 & 1 & 2 \\
\hline 23 & 2 & 22 & 21 & 21 & 38 \\
\hline 24 & 0 & $17 \frac{1}{2}$ & 22 & 6 & 0 \\
\hline 25 & 0 & 4 & 28 & 0 & 38 \\
\hline 26 & 1 & $10 \frac{1}{2}$ & 29 & 1 & 15 \\
\hline 27 & 0 & $13^{2}$ & 35 & 0 & 30 \\
\hline 30 & 0 & 37 & 36 & 0 & $29 \frac{1}{2}$ \\
\hline 31 & 1 & 25 & 40 & 4 & $16^{2}$ \\
\hline 32 & 0 & 2 & 41 & 0 & $35 \frac{1}{2}$ \\
\hline 33 & 0 & $25 \frac{1}{2}$ & 42 & 0 & 36 \\
\hline $\begin{array}{l}34 \\
37\end{array}$ & 0 & $5 \frac{1}{2}$ & & & \\
\hline $\begin{array}{l}37 \\
38\end{array}$ & $\begin{array}{l}0 \\
7\end{array}$ & 12 & \multirow{3}{*}{\multicolumn{3}{|c|}{$\begin{array}{l}19 \text { holdings with an aggregate } \\
\text { area of } 67 \text { acres, } 31 \frac{1}{2} \text { gunthas. } \\
\text { Average holding about } 3 \frac{1}{2} \\
\text { acres. }\end{array}$}} \\
\hline $\begin{array}{l}58 \\
39\end{array}$ & 1 & $11^{2}$ & & & \\
\hline 43 & 1 & 38 & & & \\
\hline \multicolumn{6}{|c|}{$\begin{array}{l}24 \text { holdings with an aggregate } \\
\text { area of } 56 \text { acres, } 32 \text { gunthas. } \\
\text { Average holding about } 2 \frac{1}{3} \\
\text { acres. }\end{array}$} \\
\hline
\end{tabular}

The land referred to in Case No. 5 is mostly rice land; but even the warkas (sloping dry-crop land) is much split up; e.g. Survey No. 179 (area 25 acres-assessment Rs.13) is split up into 22 subdivisions. It grows only grass. 
CASE No. V.

(Badlapur village, taluka Kalyan, district Thana.)

Assorted Holdings Showing Extent of Subdivision and Fragmentation.

\begin{tabular}{|c|c|c|c|}
\hline Name of Holder. & Area Held. & Assessment. & $\begin{array}{c}\text { Number } \\
\text { of } \\
\text { Separate } \\
\text { Plots. }\end{array}$ \\
\hline $\begin{array}{l}\text { Chintama.n Hari (Sowkar) } \\
\text { Vishnu Raghunath Vaidya } \\
\text { (landlord) } \\
\text { Raoji Gopal Patil . } \\
\text { Raoji Raghu Kulkarni } \\
\text { Rama Undriya Patil }\end{array}$ & $\begin{array}{cc}\text { Acres. Gunthas. } \\
18 & 6 \\
& \\
67 & 0 \\
1 & 9 \\
6 & 30 \\
24 & 0\end{array}$ & $\begin{array}{rrr}\text { Rs. } & \text { a. } & \text { p. } \\
129 & 0 & 0 \\
& & \\
137 & 0 & 0 \\
1 & 4 & 0 \\
33 & 0 & 0 \\
22 & 0 & 0\end{array}$ & $\begin{array}{r}38 \\
6 \\
8 \\
17\end{array}$ \\
\hline
\end{tabular}

CASE No. VI.

(Karla village, taluka Mawal, district Poona.)

(Typical of rice tract immediately above the Gháts.) Assorted Holdings Showing Extent of Subdivision and Fragmentation.

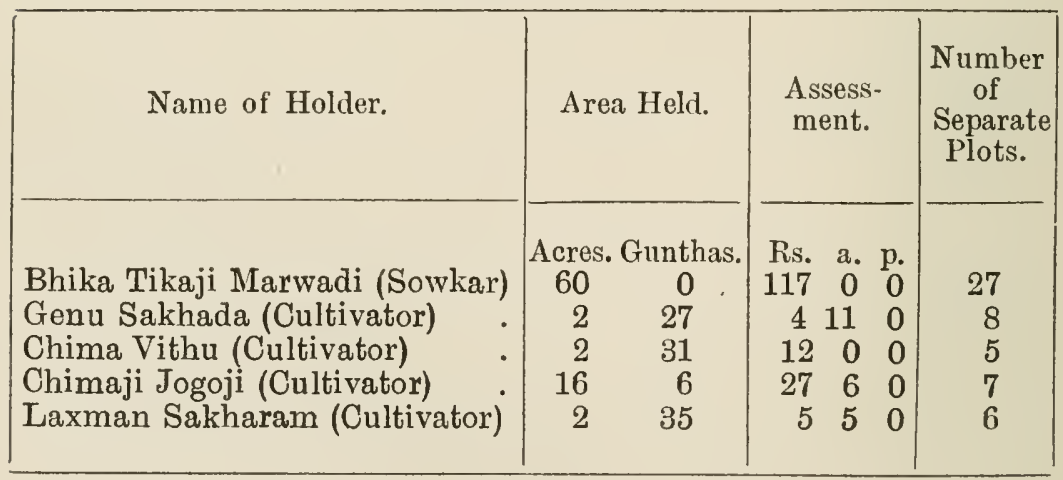

Most of the land shown in the above statement is rice land, but some bits of dry crop land are included. 


\section{B.-Gujarat.}

CASE No. VII.

(Althan village, taluka Chorasi, district Surat. Area-Acres 694. Assessment-Rs.4384.)

Land-holders 99 , of whom 54 are cultivators and 45 are non-cultivators, which gives an average of 7 acres per holding, or ignoring non-cultivators, 13 acres per holding.

The largest non-cultivator's holding amounts to 86 acres in 23 separate plots.

'The largest cultivators' holdings are :-

1. One of 41 acres, in 9 plots, the largest plot being 23 acres.

2. One of 35 acres, in 8 plots, the largest plot being 17 acres.

3. One of 26 acres, in 8 plots, the largest two of which are 6 and 5 acres respectively.

There are a good many small holdings of from 2 to 7 acres, but most of the holders of these manage to hire other land. In a few cases fragmentation has reduced the size of plots to $\frac{1}{2}$ acre, but such cases are rare.

The village has heavy black soil and is a dry-crop village growing cotton and jowari. A good cultivator aims at cultivating from 15 to 20 acres with one pair of bullocks, and a fair proportion of the cultivators secure this amount of land; so it will be recognised that from the economic point of view subdivision of land has not yet gone to any disastrous lengths. As regards fragmentation it will be noticed that it is considerable, and is certainly prejudicial, but the land is fairly level, dry-crop land, where there is no question of irrigation or garden cultivation, and comparatively little opening for permanent improvement. In such a case, provided that the individual plots amount to 3 or 4 acres, and are not too small to admit of convenient tillage operations, the loss caused by fragmentation is relatively small. In the main this is the case here. 


\section{CASE No. VIII.}

(Village Mangob, taluka Chorasi, district Surat. Area-453 acres. Assessment-Rs.3949.)

74 landholders of whom 14 are non-cultivators and 60 cultivators.

Largest non-cultivator's holding, 19 acres in one plot with a well.

Largest cultivator's holding, 14 acres of dry-crop land in one plot.

The soil in this village is lighter than in case No. VII and there are 125 acres of garden land growing vegetables, ginger, chillies, etc. The rest is dry-crop land, growing cotton and jowari. It will be seen that in this village the subdivision and fragmentation of the land is greater than in case No. VII. This is connected with the existence of garden land, and it is in such land that it is most pronounced, e.g.,

Acres. Gunthas.

$\begin{array}{lcccc}\text { Survey No. 69- } & \text { Area } & 7 & 4 & \text { divided into } 4 \text { plots. } \\ \text { Survey No. } 24- & ,, & 9 & 5 & \text { divided into } 7 \text { plots. }\end{array}$

The people say that as the garden land is subdivided the rights in the old wells are also subdivided, and the holders of rights in a single well repair the well jointly. This works fairly well up to a certain point, but they say that the subdivision of the garden land certainly checks the making of new wells, and very few are now being made, though there is plenty of suitable land where they might be made with advantage if the land was not so subdivided.

\section{CASE No. IX.}

In the garden villages of the Bulsar and Jalalpur talukas of the Surat district, where the pressure of the population on the land is greater, the subdivision and fragmentation are much more marked. The following statement gives details for some villages where it is very acute :- 


\section{APPENDIX I}

\begin{tabular}{|c|c|c|c|c|c|c|c|c|c|c|}
\hline \multirow{2}{*}{ 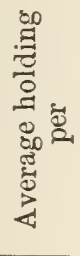 } & $\underbrace{\infty}_{0}$ & \multicolumn{2}{|c|}{ 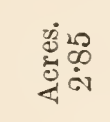 } & 맘 & \multicolumn{2}{|l|}{$\frac{\pi}{4}$} & \multirow{2}{*}{$\begin{array}{l}\text { +1 } \\
\dot{0} \\
\dot{\infty} \\
\dot{\infty}\end{array}$} & \multirow{2}{*}{$\begin{array}{c}\stackrel{P}{+1} \\
\dot{0} \\
\dot{\infty}\end{array}$} & \multirow{2}{*}{$\begin{array}{l}\frac{+1}{0+1} \\
\stackrel{+}{+} \\
\stackrel{\infty}{\infty}\end{array}$} & \multirow{2}{*}{$\begin{array}{l}\text { की } \\
\dot{m} \\
\dot{\infty} \\
\dot{\infty}\end{array}$} \\
\hline & 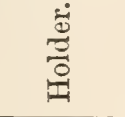 & & & $\begin{array}{l}\infty \\
\dot{\infty} \\
\dot{\infty}\end{array}$ & $\frac{m}{\dot{m}}$ & & & & & \\
\hline \multirow{3}{*}{ 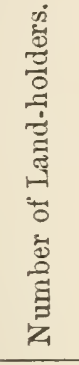 } & हैं & & $\stackrel{m}{\oplus}$ & ${ }_{10}^{0}$ & $\stackrel{P}{\not H}$ & & חొ & $\stackrel{D}{\infty}$ & $\underset{\infty}{\varnothing}$ & $\underset{\infty}{\infty}$ \\
\hline & 胥 & & $\stackrel{8}{8}$ & $\underset{\text { dv }}{\mathfrak{r}}$ & $\overrightarrow{\text { के }}$ & & $\begin{array}{l}\text { mo } \\
\text { in }\end{array}$ & 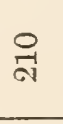 & $\stackrel{\infty}{=}$ & $\stackrel{5}{\infty}$ \\
\hline & 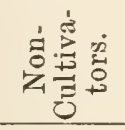 & & ๓ి & $\mathscr{~}$ & 61 & & का & $\stackrel{8}{0}$ & 可 & $\omega$ \\
\hline \multirow{3}{*}{ 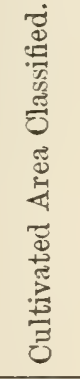 } & 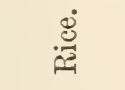 & \multirow{3}{*}{ 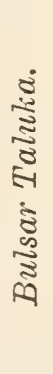 } & or & ๓े & $\begin{array}{l}0 \\
\text { क }\end{array}$ & \multirow{3}{*}{ 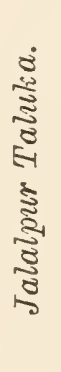 } & $\underset{F}{H}$ & ח & $\begin{array}{l}2 \\
\text { त1 } \\
201\end{array}$ & $\vec{c}$ \\
\hline & 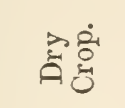 & & ₹ & ๓ి & $\begin{array}{l}\infty \\
\infty \\
\\
=1\end{array}$ & & $\frac{N}{0}$ & & $\begin{array}{l}\text { నิ } \\
\text { ผ }\end{array}$ & $\underset{ન}{ન}$ \\
\hline & 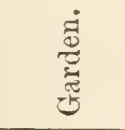 & & 豖 & $\stackrel{M}{5}$ & 엄 & & 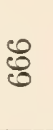 & $\stackrel{9}{\mathscr{H}}$ & 1 & 1 \\
\hline & 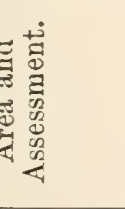 & \multicolumn{5}{|c|}{ 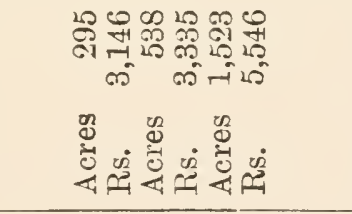 } & \multicolumn{4}{|c|}{ 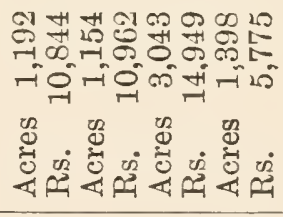 } \\
\hline & 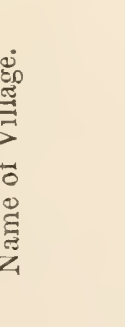 & & 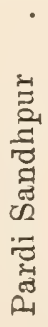 & 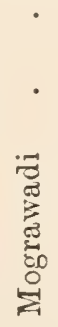 & 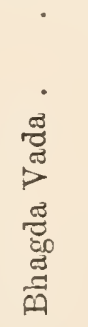 & & 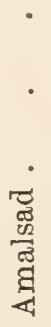 & 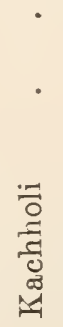 & $\begin{array}{l}. \\
. \\
\text { वై } \\
\text { बृँ } \\
\frac{\pi}{4}\end{array}$ & 离 \\
\hline
\end{tabular}


The foregoing table shows the extent of the subdivision. The extent of the fragmentation may be gathered from the following examples of large and small cultivators:-

\begin{tabular}{|c|c|c|c|}
\hline Name. & Village. & $\begin{array}{c}\text { Area } \\
\text { Cultivated. }\end{array}$ & $\begin{array}{l}\text { Number of } \\
\text { Separate } \\
\text { Plots. }\end{array}$ \\
\hline $\begin{array}{l}\text { Vasanji Sarbhai } \\
\text { Haribhai Gulab } \\
\text { Naranji Bhimbhai } \\
\text { Ganda Ratanji } \\
\text { Khandubhai Mohanbhai }\end{array}$ & $\begin{array}{l}\text { Pardi Sandhpur } \\
\text { ", } \\
\text { Mograwadi } \\
\text { Pardi Sandhpur } \\
\qquad,\end{array}$ & $\begin{array}{c}\text { Acres. } \\
18 \\
13 \\
22 \\
3 \\
5\end{array}$ & $\begin{array}{r}14 \\
18 \\
20 \\
4 \\
7\end{array}$ \\
\hline
\end{tabular}

In the same group of villages the following examples may be given of individual fields where the fragmentation is very excessive :-

1. Village Abrama. Survey No. 218. Area 1 acre 26 gunthas. Assessment Rs.28. (Bagayat.)

\begin{tabular}{|c|c|c|}
\hline Separate Plots. & Area. & Crop Grown in 1915. \\
\hline $\begin{array}{l}1 \\
2 \\
3 \\
4 \\
5 \\
6 \\
7 \\
8\end{array}$ & $\begin{array}{cc}\text { Acres. Gunthas. } & \text { G } \\
0 & 9 \\
0 & 9 \\
0 & 10 \\
0 & 32 \\
0 & 3 \\
0 & 1 \\
0 & 1 \\
0 & 1\end{array}$ & $\begin{array}{l}\text { Sugar-cane } \\
\text { Dry rice } \\
\text { Wal" } \\
\text { Guvar } \\
\text { Uncultivated } \\
\text { Dry rice }\end{array}$ \\
\hline
\end{tabular}


2. Village Abrama. Survey No. 370. Area 26 gunthas. Assessment Rs.13-8-0. (Rice land.)

\begin{tabular}{|c|c|c|}
\hline Separate Plots. & Area. & Crop Grown in 1915. \\
\hline $\begin{array}{l}1 \\
2 \\
3 \\
4 \\
5 \\
6 \\
7 \\
8 \\
9\end{array}$ & $\begin{array}{cc}\text { Acres. } & \text { Gunthas. } \\
0 & 2 \\
0 & 1 \\
0 & 2 \\
0 & 2 \\
0 & 1 \\
0 & 1 \\
0 & 2 \\
0 & 6 \\
0 & 9\end{array}$ & $\begin{array}{l}\text { Uncultivated } \\
\text { Rice }\end{array}$ \\
\hline
\end{tabular}

3. Village Pardi Sandhpur-Survey No. 28, area 3 acres 25 gunthas, assessment $\mathrm{Rs.44}$-is divided into 21 separate plots, and the whole was uncultivated in 1915.

From the above three cases it will be noticed that when the fragments become very small they tend to go out of cultivation.

\section{CASE No. $X$.}

In some parts of Northern Gujarat also, and particularly in the Chharotar subdivision, fragmentation of holdings has reached great lengths. Three statements are here given showing, for three villages in the Kaira district, the extent of the subdivision and fragmentation of particular holdings and of particular fields.

1.-Showing Extent of Subdivision.

\begin{tabular}{|c|c|c|c|c|c|c|}
\hline \multirow{2}{*}{$\begin{array}{l}\text { Serial } \\
\text { No. }\end{array}$} & \multirow{2}{*}{$\begin{array}{l}\text { Name of the } \\
\text { Village. }\end{array}$} & \multirow{2}{*}{$\begin{array}{l}\text { Occupied } \\
\text { Area. }\end{array}$} & \multirow{2}{*}{ Assessment. } & \multicolumn{2}{|c|}{$\begin{array}{l}\text { Number of } \\
\text { Holders. }\end{array}$} & \multirow{2}{*}{$\begin{array}{c}\text { Average } \\
\text { Holding } \\
\text { Per } \\
\text { Cultivator }\end{array}$} \\
\hline & & & & $\begin{array}{l}\text { Agricul- } \\
\text { turists. }\end{array}$ & $\begin{array}{l}\text { Non- } \\
\text { Agricul- } \\
\text { turists. }\end{array}$ & \\
\hline $\begin{array}{l}1 \\
2 \\
3\end{array}$ & $\begin{array}{l}\text { Saloon } \\
\text { Uttarsanda } \\
\text { Dabhan . }\end{array}$ & $\begin{array}{cr}\text { A. } & \text { g. } \\
2418 & 7 \\
2231 & 19 \\
1997 & 18\end{array}$ & $\begin{array}{ccc}\text { Pis. } & \text { a. } & \text { p. } \\
14,018 & 0 & 0 \\
14,095 & 2 & 0 \\
14,251 & 1 & 0\end{array}$ & $\begin{array}{l}438 \\
484 \\
450\end{array}$ & $\begin{array}{r}109 \\
86 \\
92\end{array}$ & $\begin{array}{c}\text { Acres. } \\
5 \cdot 52 \\
4 \cdot 60 \\
4 \cdot 43\end{array}$ \\
\hline
\end{tabular}




\begin{tabular}{|c|c|c|c|c|c|}
\hline 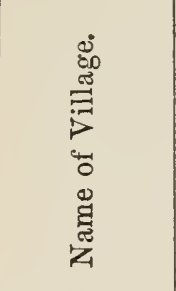 & 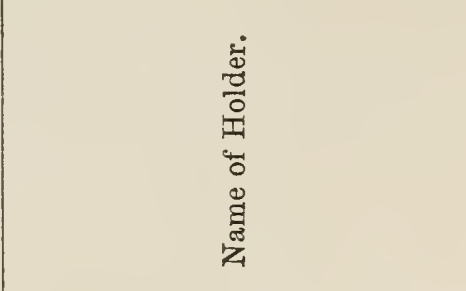 & 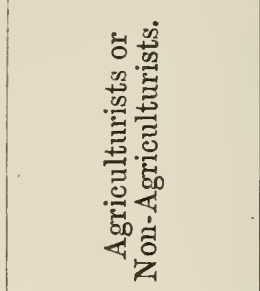 & 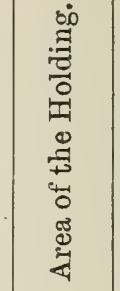 & 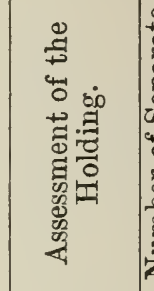 & 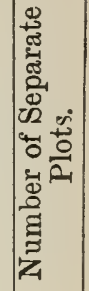 \\
\hline Saloon & Big Holders. & & A. g. & Rs. a.p. & \\
\hline $\begin{array}{l}1 \\
2 \\
3 \\
4 \\
5 \\
6\end{array}$ & $\begin{array}{l}\text { Patel Kishorbhai Jijibhai } \\
\text { ", Mathrubhai Jeshangbhai } \\
\text { Marghabhai Ichhabhai } \\
\text { Tribhovanotalal Mansulkhbhai } \\
\text { Hiralal Shivlal }\end{array}$ & $\begin{array}{c}\text { Agriculturist } \\
, ", \\
\text { Non-agriculturist } \\
, "\end{array}$ & $\left|\begin{array}{ll}62 & 13 \\
65 & 34 \\
36 & 16 \\
45 & 29 \\
13 & 30 \\
11 & 39\end{array}\right|$ & $\begin{array}{rrr}328 & 0 & 0 \\
412 & 0 & 0 \\
256 & 0 & 0 \\
275 & 0 & 0 \\
61 & 0 & 0 \\
62 & 0 & 0\end{array} \mid$ & \begin{tabular}{l|l}
0 & 27 \\
0 & 23 \\
0 & 23 \\
0 & 16 \\
0 & 7 \\
0 & 9
\end{tabular} \\
\hline $\begin{array}{l}1 \\
2 \\
3 \\
4 \\
5 \\
6\end{array}$ & \begin{tabular}{l}
\multicolumn{1}{c}{ Small Holders. } \\
Patel Chhagan Revandas \\
"' Vaghaji Somabhai \\
Desai Motibhai Shaukerbhai \\
Laxmishanker Prabhushanker \\
Laxminarayan Parsadrai \\
Shah Valavdas Gangadas
\end{tabular} & $\begin{array}{c}\text { Agriculturist } \\
\text {,", } \\
\text { Non-agriculturist } \\
,, \\
, "\end{array}$ & $\left|\begin{array}{rr}7 & 9 \\
5 & 26 \\
13 & 16 \\
3 & 14 \\
11 & 12 \\
8 & 32\end{array}\right|$ & $\left|\begin{array}{rrr}53 & 4 & 0 \\
25 & 1 & 0 \\
70 & 0 & 0 \\
18 & 15 & 0 \\
71 & 0 & 0 \\
47 & 12 & 0\end{array}\right|$ & $\begin{array}{ll}0 & 5 \\
0 & 5 \\
0 & 6 \\
0 & 2 \\
0 & 3 \\
0 & 3\end{array}$ \\
\hline Uttarsanda & Big Holders. & & & & \\
\hline $\begin{array}{l}1 \\
2 \\
3 \\
4 \\
5 \\
6\end{array}$ & $\begin{array}{l}\text { Patel Ishvarbhai Bhulabhai } \\
\text { ", Mathurbhai Muljibhai } \\
\text { ", Lalubhai Narerbhai } \\
\text { Morlidhar Maharaj } \\
\text { Jamietram Shivlal } \\
\text { Narandas Motiram Sadhu }\end{array}$ & $\begin{array}{c}\text { Agriculturist } \\
\text { ", } \\
\text { Non-agriculturist } \\
\text {,", }\end{array}$ & $\left|\begin{array}{rr}28 & 4 \\
12 & 10 \\
12 & 7 \\
70 & 24 \\
12 & 7 \\
12 & 20\end{array}\right|$ & $\begin{array}{rrr}186 & 6 & 0 \\
69 & 9 & 0 \\
79 & 14 & 0 \\
378 & 0 & 0 \\
73 & 10 & 0 \\
74 & 9 & 0\end{array}$ & \begin{tabular}{r|r}
0 & 15 \\
0 & 8 \\
0 & 3 \\
0 & 18 \\
0 & 4 \\
0 & 9
\end{tabular} \\
\hline $\begin{array}{l}1 \\
2 \\
3 \\
4 \\
5 \\
6\end{array}$ & $\begin{array}{l}\text { Sinall Holders. } \\
\text { Patel Kishorbhai Bavaji } \\
\text { ", Babarbhai Zaverbhai } \\
\text { Gor Jagankerbhai Manorbhai } \\
\text { Mansulkhath Shanker Haribhai } \\
\text { Motilal Nagar }\end{array}$ & $\begin{array}{c}\text { Agriculturist } \\
\text { ", } \\
\text { Non-agriculturist } \\
, "\end{array}$ & $\begin{array}{ll}5 & 26 \\
5 & 34 \\
3 & 39 \\
4 & 34 \\
5 & 5 \\
5 & 24\end{array}$ & $\mid \begin{array}{rrr}35 & 8 & 0 \\
35 & 11 & 0 \\
22 & 0 & 0 \\
29 & 9 & 0 \\
30 & 0 & 0 \\
30 & 0 & 0\end{array}$ & $\begin{array}{l}5 \\
5 \\
3 \\
4 \\
2 \\
8\end{array}$ \\
\hline Dabhan & Big Holders. & & & & \\
\hline $\begin{array}{l}1 \\
2\end{array}$ & $\begin{array}{l}\text { Patel Kishbhai Becharbhai } \\
\text { ", Gokalbhai Kuberbhai }\end{array}$ & Agriculturist & $\begin{array}{ll}24 & 38 \\
23 & 10\end{array} \mid$ & $\begin{array}{rrr}173 & 12 & 6 \\
172 & 6 & 0\end{array} \mid$ & $\begin{array}{l}13 \\
15\end{array}$ \\
\hline $\begin{array}{l}3 \\
4\end{array}$ & $\begin{array}{l}\text { Naranbhai Dadabhai } \\
\text { Acharya Shripatprasad Biharilal }\end{array}$ & Nou-agriculturist & $\left|\begin{array}{ll}14 & 36 \\
59 & 18\end{array}\right|$ & $\left|\begin{array}{lll}113 & 9 & 0 \\
426 & 6 & 6\end{array}\right|$ & $\begin{array}{l}13 \\
62\end{array}$ \\
\hline $\begin{array}{l}5 \\
6\end{array}$ & $\begin{array}{l}\text { Pandya Dolatram Kirparam } \\
\text { Pandya Dhirajlal Rauchlod }\end{array}$ & ", & $\left|\begin{array}{ll}21 & 17 \\
8 & 24\end{array}\right|$ & $\left|\begin{array}{rrr}145 & 4 & 0 \\
58 & 9 & 0\end{array}\right|$ & 12 \\
\hline 1 & $\begin{array}{l}\text { Simall Holders. } \\
\text { Patel Chakabhai }\end{array}$ & Agriculturist & 726 & $\begin{array}{lll}56 & 10 & 0\end{array}$ & 5 \\
\hline 0 & $\begin{array}{l}\text { Bai Nathi (Patel Nathurabhai } \\
\text { Girdhar's daughter). }\end{array}$ & & & & 8 \\
\hline $\begin{array}{l}3 \\
4\end{array}$ & $\begin{array}{l}\text { Patel Motibhai Muljibhai } \\
\text { Jamietram Pranshanker Bhatt }\end{array}$ & Non-agriculturist & $\begin{array}{l}716 \frac{1}{2} \\
723\end{array}$ & $\left|\begin{array}{lll}52 & 2 & 6 \\
56 & 0 & 0\end{array}\right|$ & $\begin{array}{r}18 \\
4\end{array}$ \\
\hline$\sigma$ & $\begin{array}{l}\text { Narmadashanker Chlaganlal } \\
\text { Bhatt }\end{array}$ & & 534 & & 4 \\
\hline 6 & Mansukhram Vidyaram & & $\begin{array}{lll}5 & 18\end{array}$ & $\begin{array}{lll}45 & 15 & 0\end{array}$ & 6 \\
\hline
\end{tabular}




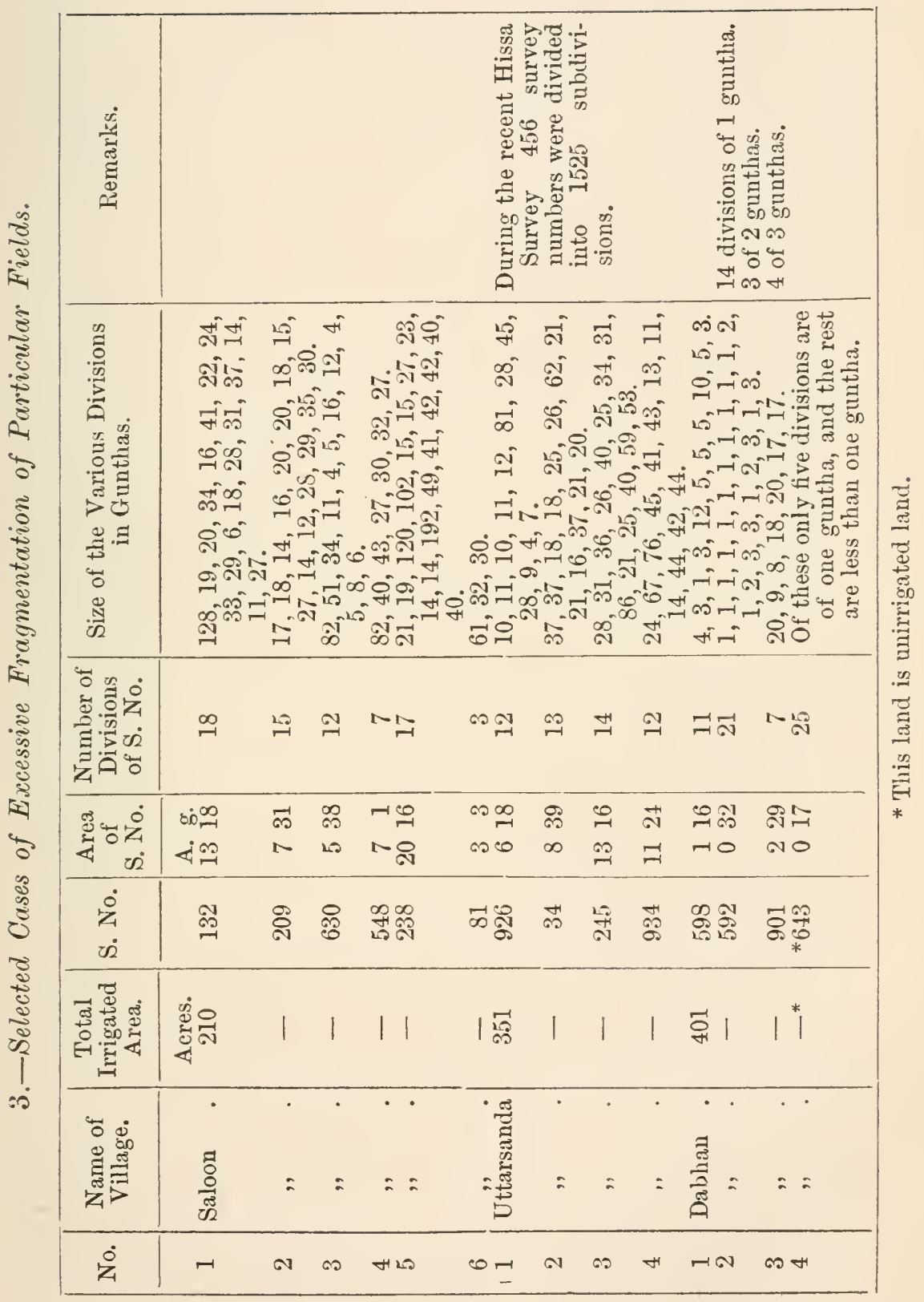




\section{C.- DECCAN.}

The problem differs considerably between the West Deccan and the East Deccan.

In parts of the West Decean where the rainfall is fairly regular and other conditions favourable, the pressure of the population on the cultivable land is often considerable. In the East Deccan it is usually far less.

CASE No. XI.

The tables given below show the extent of the subdivision in five villages situated in the Koregaon taluka, Satara district, under markedly favourable West Deccan conditions. They are distinctly non-irrigated villages, though a few wells exist. Most of their crops are kharif, but they have some rabi.

\begin{tabular}{|c|c|c|c|}
\hline Name of Village. & $\begin{array}{l}\text { Average } \\
\text { Assessment } \\
\text { Per Acre. }\end{array}$ & $\begin{array}{c}\text { Average Size } \\
\text { of Holding } \\
\text { held by } \\
\text { Agriculturists. }\end{array}$ & $\begin{array}{l}\text { Area held by } \\
\text { Non-Cultivators } \\
\text { and Leased out } \\
\text { to Cultivators. }\end{array}$ \\
\hline $\begin{array}{l}\text { 1. Tadvala : } \\
\text { 2. Jalgaon : } \\
\text { 3. Khed } \\
\text { 4. Tripoti : } \\
\text { 5. Apsinge : }\end{array}$ & $\begin{array}{r}\text { Rs. } \\
3.03 \\
1.87 \\
1.70 \\
1.23 \\
.98\end{array}$ & $\begin{array}{r}\text { Acres. } \\
5 \cdot 96 \\
5 \cdot 19 \\
6.09 \\
8.32 \\
14 \cdot 26\end{array}$ & $\begin{array}{c}\text { Acres. } \\
22 \\
741 \\
541 \\
282 \\
33\end{array}$ \\
\hline
\end{tabular}

The table opposite shows for the same five villages further details regarding the size of the holdings.

It will be noticed that in villages where the average assessment per acle varies from Rs.3 to Re.1 the size of the agriculturists' holdings varies from 6 acres to 14 acres. It is only in Apsinge where a large part of the land is of poor quality that the average holding excecds 9 acres. No doubt the land held by non-agriculturists is leased out to some of the smaller holders and gives them some additional area to cultivate; but this relief does not amount to anything very 


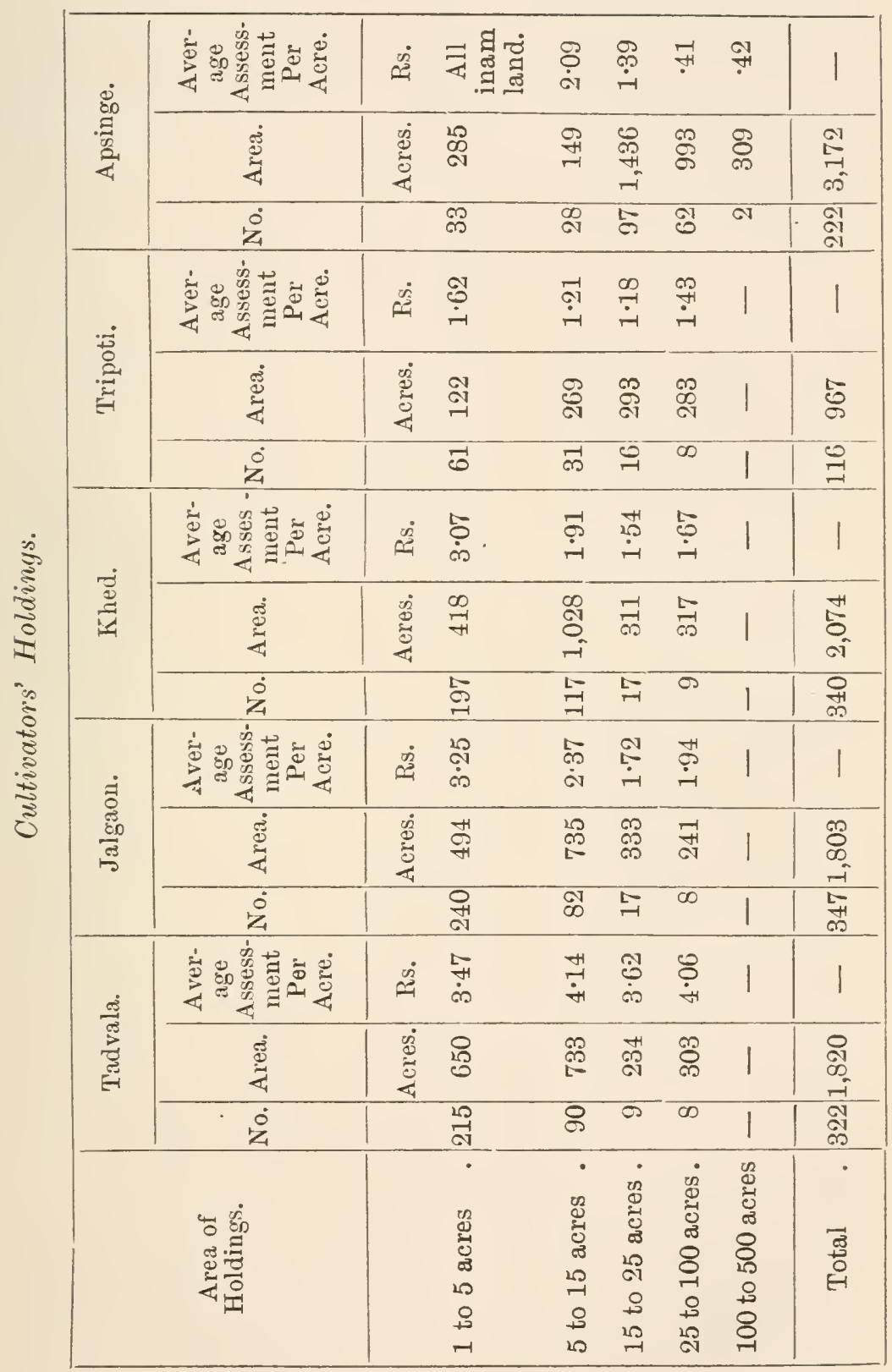


material. The great bulk of the holdings have an area of less than 15 acres each. The best land is for the most part divided up into very small holdings.

CASE No. XII.

The village of Lhasurna, taluka Koregaon, district Satara, is close to the five villages mentioned in case No. XI. The average size of the holding is 5 acres, and the average assessment per acre for the village is R.2.63. There are 100 acres under patasthal irrigation.

The following instances give an idea of the fragmentation of holdings :-

Survey No. 67 (patasthal), area 38 gunthas, is divided amongst 6 holders. Average size of each plot, $6 \frac{1}{3}$ gunthas.

Survey No. 70 (patasthal), area 23 gunthas, is divided amongst 7 holders. Average size of plot, $3 \frac{1}{4}$ gunthas. Survey No. 71 (patasthal), area 36 gunthas, is divided amongst 3 holders. Average size of plot, 12 gunthas. Survey No. 102, Pôt No. 13 (dry land), area 22 gunthas, is divided into 10 plots belonging to 10 different men. Average size of plot, $2 \frac{1}{5}$ gunthas. As a result of this extreme fragmentation it has been uncultivated for years past.

CASE No. XIII.

The village of Pimpla Soudagar, 9 miles from Poona, was selected by Dr. Mann for conducting an economic survey, and he recorded the following facts:-

Occupied al'ea

Assessment .

Number of holdings

Average size of holding

Number of separate plots owned

Average number of plots per holding .

Number of separate plots separately cultivated .
951 acres.

Rs. 1660

156

7 acres.

711

$4 \frac{1}{2}$ 
CASE No. XIV.

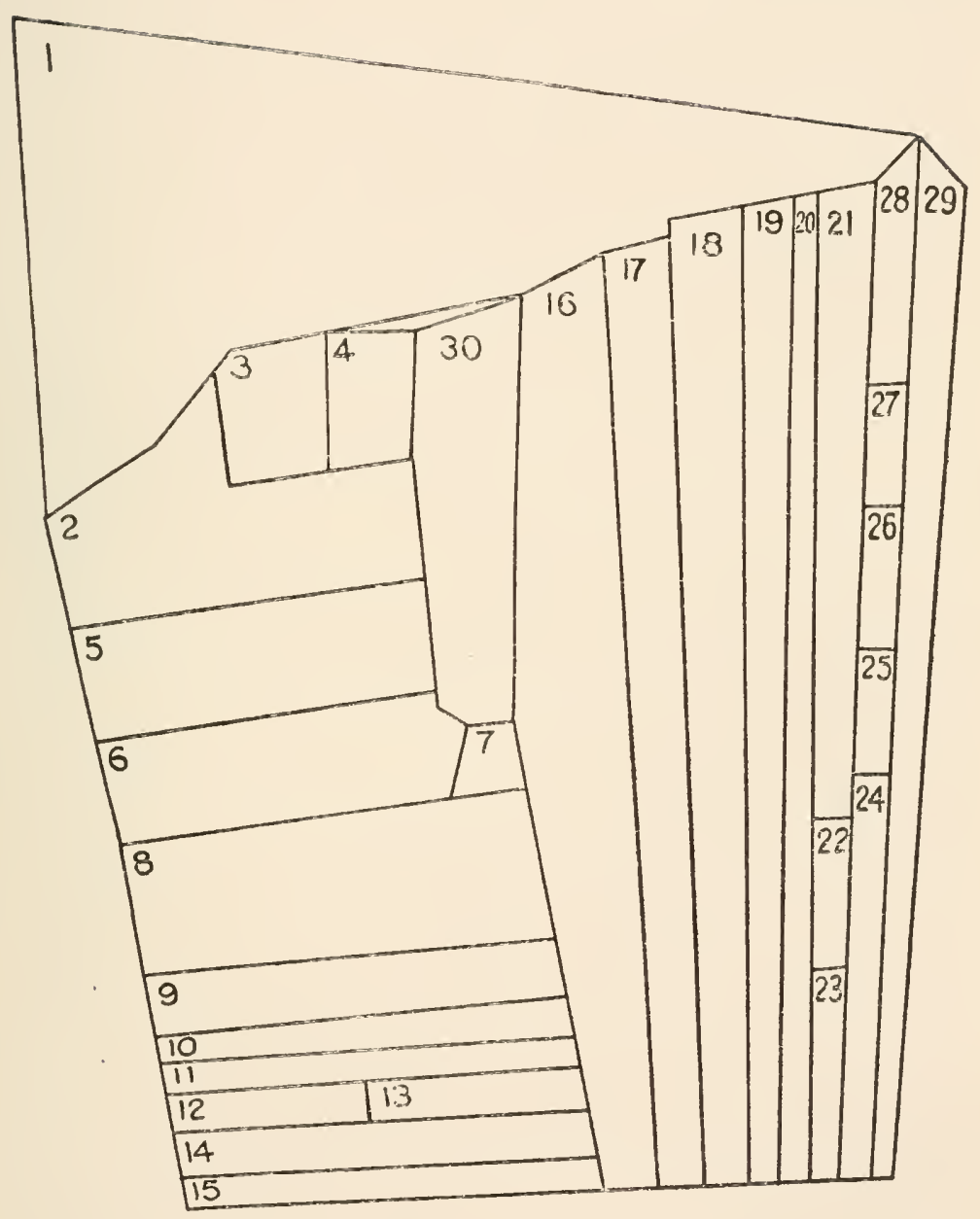




\begin{tabular}{|c|c|c|c|c|c|c|}
\hline \multirow{2}{*}{$\begin{array}{l}\text { Survey } \\
\text { No. }\end{array}$} & \multirow{2}{*}{$\begin{array}{l}\text { Part of } \\
\text { Pôts No. }\end{array}$} & \multicolumn{2}{|c|}{ Area. } & \multicolumn{3}{|c|}{ Assessment. } \\
\hline & & A. & G. & R. & A. & P. \\
\hline \multirow[t]{2}{*}{92} & $\begin{array}{r}1 \\
2 \\
3 \\
4 \\
5 \\
6 \\
7 \\
8 \\
9 \\
10 \\
11 \\
12 \\
13 \\
14 \\
15 \\
16 \\
17 \\
18 \\
19 \\
20 \\
21 \\
22\end{array}$ & $\begin{array}{l}3 \\
3 \\
0 \\
1 \\
1 \\
2 \\
1 \\
1 \\
2 \\
3 \\
1 \\
2 \\
2 \\
0 \\
0 \\
1 \\
1 \\
2 \\
0 \\
1\end{array}$ & $\begin{array}{r}21 \\
30 \\
39 \\
0 \\
24 \\
23 \\
8 \\
12 \\
20 \\
27 \\
34 \\
32 \\
20 \\
30 \\
31 \\
1 \\
33 \\
17 \\
39 \\
35 \\
8 \\
38\end{array}$ & $\begin{array}{l}4 \\
4 \\
1 \\
1 \\
2 \\
3 \\
1 \\
1 \\
3 \\
4 \\
2 \\
3 \\
3 \\
0 \\
0 \\
1 \\
2 \\
2 \\
1 \\
2 \\
1 \\
1\end{array}$ & $\begin{array}{r}10 \\
15 \\
4 \\
5 \\
2 \\
7 \\
9 \\
10 \\
7 \\
10 \\
8 \\
9 \\
5 \\
14 \\
14 \\
2 \\
2 \\
12 \\
2 \\
3 \\
6 \\
2\end{array}$ & $\begin{array}{l}0 \\
0 \\
0 \\
0 \\
0 \\
0 \\
0 \\
0 \\
0 \\
0 \\
0 \\
0 \\
0 \\
0 \\
0\end{array}$ \\
\hline & & 41 & 10 & 51 & 14 & \\
\hline
\end{tabular}




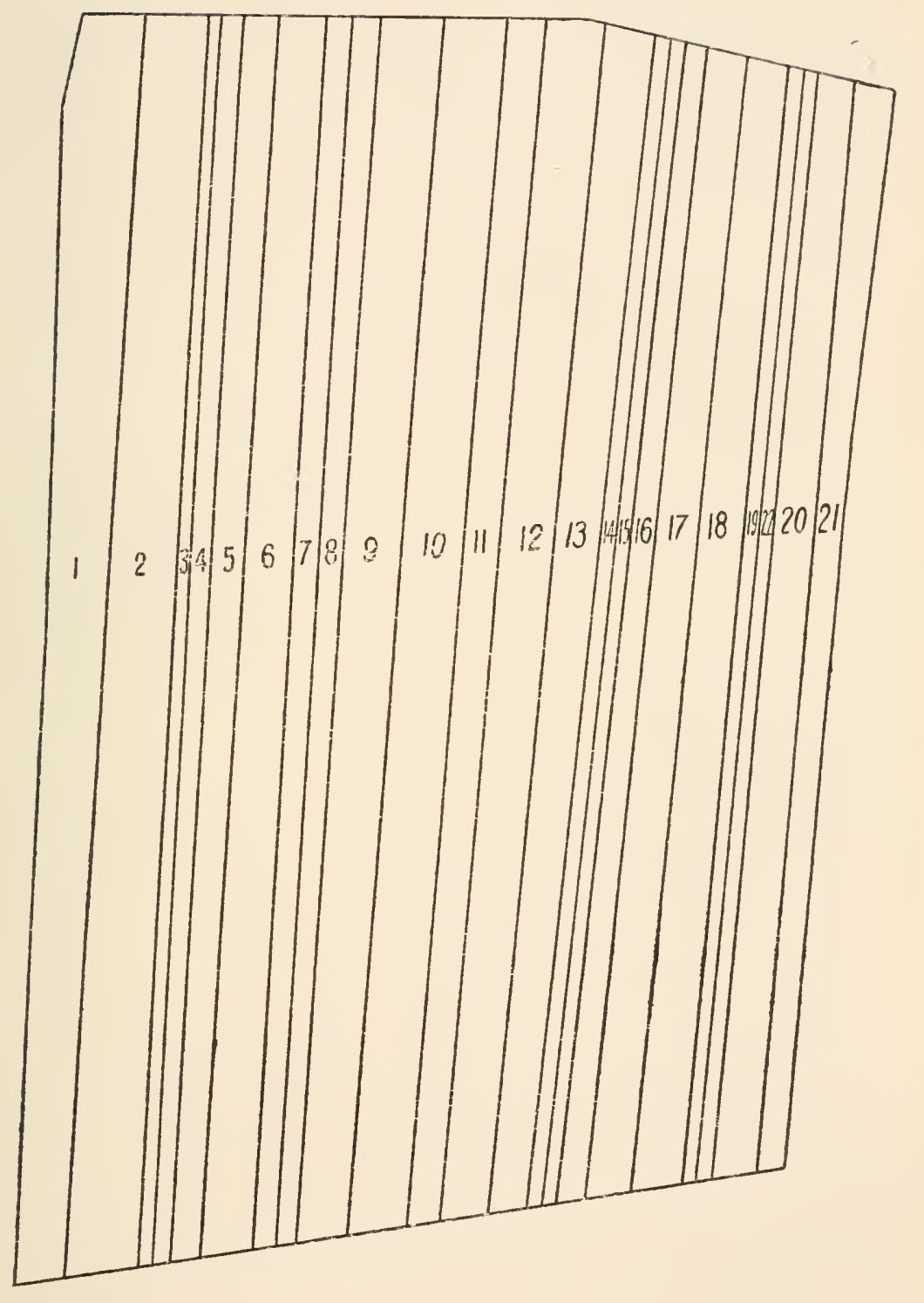




\begin{tabular}{|c|c|c|c|c|c|c|}
\hline \multirow{2}{*}{$\begin{array}{c}\text { Survey } \\
\text { No. }\end{array}$} & \multirow{2}{*}{$\begin{array}{l}\text { Part of } \\
\text { Pôts No. }\end{array}$} & \multicolumn{2}{|c|}{ Area. } & \multicolumn{3}{|c|}{ Assessment. } \\
\hline & & A. & G. & P. & A. & P. \\
\hline \multirow[t]{2}{*}{54} & $\begin{array}{r}1 \\
2 \\
3 \\
4 \\
5 \\
6 \\
7 \\
8 \\
9 \\
10 \\
11 \\
12 \\
13 \\
14 \\
15 \\
16 \\
17 \\
18 \\
19 \\
20 \\
21 \\
22 \\
23 \\
24 \\
25 \\
26 \\
27 \\
28 \\
29 \\
30\end{array}$ & $\begin{array}{l}2 \\
2\end{array}$ & $\begin{array}{r}27 \\
25 \\
16 \\
12 \\
5 \\
5 \\
4 \\
30 \\
29 \\
15 \\
15 \\
10 \\
10 \\
20 \\
19 \\
11 \\
28 \\
31 \\
36 \\
27 \\
31 \\
6 \\
7 \\
15 \\
5 \\
7 \\
7 \\
10 \\
35 \\
2\end{array}$ & $\begin{array}{l}5 \\
5 \\
3 \\
0\end{array}$ & $\begin{array}{r}13 \\
9 \\
14 \\
10 \\
7 \\
7 \\
3 \\
12 \\
9 \\
13 \\
13 \\
8 \\
8 \\
1 \\
1 \\
14 \\
11 \\
14 \\
15 \\
8 \\
11 \\
5 \\
6 \\
13 \\
4 \\
6 \\
6 \\
8 \\
15 \\
5\end{array}$ & $\begin{array}{l}0 \\
0 \\
0\end{array}$ \\
\hline & & 23 & 20 & 51 & 0 & 0 \\
\hline
\end{tabular}

CASE No. XIV.

The maps and explanatory statements given on pages 217 to 220 of two survey numbers (92 and 54) of Mundhwa village, near Poona, both under canal irrigation, show not only great 
fragmentation of the land, but indicate also the very awkward and unsuitable shapes into which the plots are divided. Some of these narrow strips running the whole length of the field are only 22 feet wide. Such a division makes effective tillage and irrigation impossible.

\section{CASE No. XV.}

In the case of poorer land the amount of subdivision and fragmentation is naturally less so far as the figures are concerned, though from the economic point of view matters are often at least as bad.

The following figures are for the village of Khadki, taluka Man, district Satara. The soil is of the poorest and the rainfall as capricious as anything in the Decean. The lands of this village may be taken as representing land on the very margin of cultivation, indeed most of them are well below the economic margin :-

Occupied area . . . . 2716 acres.

Assessment . . . Rs.544

Average assessment per acre . 3 annas, 1 pie.

Number of land-holders . . 160

Number of separate plots _ $\quad 825$

Average size of holding . . 17 acres.

Average size of plot . . . $2 \frac{1}{2}$ acres.

In the great majority of holdings, however, the size of the separate plots is much bigger than this. The patil has the largest holding with 137 acres divided into 17 plots, the average size of each plot being 8 acres. It is in the survey numbers which contain a well that fragmentation is marked, e.g.-

Survey No. 191 : area 16 acres; assessment Rs.4.

There are 14 separate plots in this field, belonging to 14 separate persons, and each of these per'sons has a share in the one well in the field. 
Survey No. 201 : area 20 acres; assessment Rs.10.

There are 22 separate plots in this field belonging to 22 separate persons, and each of these persons has a share in the one well in the field.

\section{CASE No. XVI.}

The figures given below are for a tract where the pressure of population on the land is comparatively small and the holdings still fairly large :-

Arvi, taluka Dhulia, district West Khandesh :-

Occupied area . . 3698 acres.

Assessment . . Rs.2150

Average assessment About 9 annas per acre.

36 holders have holdings of less than 10 acres.

74 holders have holdings from 10 to 20 acres.

60 holders have holdings from 20 to 50 acres.

9 holders have holdings above 50 acres.

Anawadki, taluka Dhulia, district West Khandesh :-

Occupied area .

Assessment

Average assessment
- 1300 acres.

Rs.556

7 annas per acre.

The Marwadi money-lender owns 356 acres which he leases out to others.

Of the remaining land 7 holdings aggregating 411 acres are between 50 and 70 acres each. The remaining 33 holdings, aggregating 533 acres, average out at 16 acres apiece.

The land of the above two villages is light soil, growing bajri and cotton, and the amount of irrigation is negligible.

\section{CASE No. XVII.}

The last case refers to a typical cotton village in the East Deccan, where the soil is deep, the rainfall somewhat pre- 


\section{APPENDIX I}

carious and the pressure of population on the soil comparatively small.

Murgundi, taluka Athni, district Belgaum-

Occupied area . . . . . 2327 acres.

Number of holdings . . . 153

Average area of holding . . 15 acres.

Number of separate plots 327 , i.e. slightly over 2 per holding.

It will be seen that here neither subdivision nor fragmentation is acute.

Fragmentation occurs, however, e.g.,

Holding $A, 31$ acres in 7 plots.

Holding B, 12 acres in 6 plots.

Holding $\mathrm{C}, 30$ acres in 8 plots.

Per contra many of the other holdings are unfragmented. There are 113 working bullocks, i.e. one pair for 40 acres. 


\section{APPENDIX II.}

THE EXTENT OF FRAGMENTATION AND SUBDIVISION OF HOLDINGS IN OTHER COUNTRIES, THE CAUSES OF THE SAME AND THE REMEDIAL MEASURES TAKEN.

(N.B.-Most of the facts referred to in this appendix have been collected from writings published prior to 1914. As a result of the war, the facts, as here stated, now need modification in some cases, and must be taken as correct only down to 1914. This, however, does not affect their value for the purpose for which they are quoted.)

A. England.-In England, as is well known, the Law of Entail, the custom of primogeniture and the difficulties involved in the conveyancing of land have resulted in the concentration of the land in the hands of a very few persons. It was estimated * not very long ago that there are in Great Britain not mole than 250,000 owners of land, and that fourfifths of the land belongs to about 7000 persons. Consequently there has been in England no question of excessive subdivision of land-indeed the problem has been the exact reverse, viz. the over-concentration of land in the hands of a few people; and the land legislation that has been undertaken or projected in recent years has been intended to encourage and promote subdivision of land and to bring small holders into existence.

B. France.-In France the situation is the opposite of that * " Free Laud," by Arthur Arnold (1880). 
in England. The Code Napoleon enacts that on the death of the father property must be equally divided amongst all the children, and limits the parental power of testamentary disposition of property to a part equal to one child's share. This law was bequeathed to France by the authors of the French Revolution. It is designed to promote equality, and to secure the rights of the whole community in the distribution of public wealth. Even before the French Revolution there were many small holdings in France, but it is undoubtedly the case that the operation of this law has caused and continues to cause a great subdivision (and incidentally fragmentation) of holdings. It has roughly been estimated * that in France there are 5,000,000 land-owners who own estates averaging $7 \frac{1}{2}$ acres each, 500,000 who own estates averaging 75 acres each, and 50,000 who own estates averaging 750 acres each. It is asserted that together with the subdividing action of the law, another consolidating force is in operation, which arises from the fact that the peasants are very hard-working and frugal, and manage to save enough money to purchase small parcels of land adjoining their own, and to round off their own small properties. The fact that in France families are usually small also mitigates the evil. Still in some parts of France the holdings have been subdivided and fragmented to an extent which is very prejudicial to effective production, and a demand has arisen + in France for a modification of the law which leads to such results, with a view to creating peasant holdings of the right size and shape, and to reconstituting into solid holdings the existing scattered plots. This demand has never been met in full by legislation, but Acts $\ddagger$

* "Economie Rurale de la France," by M. de Lavergne (1875).

†"Economie Rurale," by M. Jouzier, pp. $344-55$ (1903). "Bulletin of Economic and Social Intelligence" for December, 1910, issued by the International Insticute of Agriculture, Rome.

¥"Economie Rurale," by M. Jouzier, pp. $344-55$ (1903). " Bulletin of Economic and Social Intelligence" for February, 1914. 


\section{SUBDIVISION IN OTHER COUNTRIES}

passed in 1908, 1909 and 1910 allow every farmer to voluntarily place beyond the possibility of expropriation and seizure for debt a holding of a value not exceeding 8000 francs (Rs.5000) which is occupied and worked by his family. This holding remains a joint family property. It is now proposed to extend the scope of this law, presumably in the directions already taken in other European countries (vide post).

C. Germany.-In Germany the Law of Inheritance varies greatly in the different States. In Prussia the law and custom favour the formation of large estates, while in Southern Germany the reverse is the case.

In Wurtemberg a certain moderate portion, defined by law, of the father's property passes to each child, and over the remainder the father is allowed liberty of disposition. So far as is possible, an effort is made to leave a small farm intact to a single son, but it frequently happens that the daughters are on their marriage allotted a share of the paternal land, and as the husband is probably the possessor of a piece of land elsewhere in the commune, the subdivision and intersection of land became serious, and it was estimated * in 1880 that the land in Wurtemberg was held by 280,000 peasant owners with less than 5 acres each, as against 160,000 proprietors of estates of more than 5 acres each.

In Bavaria part of the State has adopted the Law of Inheritance laid down by the Code Napoleon, and in the other part the law ordains t that on the death of the father one-third to one-half of his property (according to the size of the family) must be divided equally amongst his children, and over the remainder he can exercise a testamentary disposition. Great efforts are made by the peasants to keep their farms intact, but the land has become much subdivided.

* "Agrarian Legislation in Germany During the Present Century," by R. B. D. Morier (1880).

†"The Law and Custom of Primogeniture," by the Hon, G, C. Brodrick, 
In his "Report on the Tenure of Land in the Grand Duchy of Hesse," submitted to the Foreign Office in 1870, Mr. R. B. D. Morier makes the following interesting remarks:-

"In the great majority of cases the holdings are dispersed over the arable land of the community in single parcels intersected by those of other holdings. In many parts of the Grand Duchy the subdivision arising from these causes has reached an intolerable pitch, and various consoliclating Acts have been passed for the purpose of remedying the evil. These Acts have, however, only been partially successful, and a new measure is being at the present moment prepared which, it is hoped, will prove more efficacious. In the districts in which tine consolidated farms are situated, immemorial custom has ruled that the property in its entirety descends to one child, almost invariably the eldest son, and the younger children do not avail themselves of their un. doubted right to claim their pars legitima, though it is, of course, usual that some sort of provision is made for them."

During the past thirty years much work has been done in Germany in the way of creating and resettling peasants' holdings on an economic basis. This work has been entrusted to Land Commissions which have been created by the legislative enactments of various States dating from the serenties and eighties. In Prussia eight General Commissions exist for settling land on an economic basis either by the subdivision of large estates, by restriping, or by the occupation and improvement of waste lands. The aggregate area of the economic holdings so formed is about $1,350,000$ acres. The economic holdings so formed may not be subdivided nor may they be added to the lands of large land-holders.*

A short account + may be given of the work undertaken by the Commission in West Prussia where the main problem

* "Bulletin of Economic and Social Intelligence" for March, 1912.

+ Ibid., December, 1912, published by the International Institute of Agriculture, Rome. 


\section{SUBDIVISION IN OTHER COUNTRIES}

is to divide up large estates into small ones and to settle peasant farmers on improved waste lands. This Commission was founded by a law of 1886 which gave the Commission certain powers and placed at its disposal a fund of $100,000,000$ marks. With this money the Commission buys large estates, divides them into suitable small farms, and contributes to the necessary expenses of the settlements. These small farms are given out-

1. On lease for definite periods.

2. On freehold, on payment of the price.

3. On purchase by instalment, and subject to certain clefinite conditions.

System No. 3 is the most popular.

By a law of 1896 the small farms, so formed, can be subdivided or separated into parts only with the consent of the Commission. They can be transferled to persons outside the family of the holder only with the consent of the Commission, but this consent can be refused only when the effect of the transfer would be to merge the farm in a larger estate. To preserve the farm intact the law of 1896 subjects these farms to special laws of inheritance differing from the principle of equality of heirs as established by the German Civil Code of the same year. The law lays down that in the absence of testamentary disposition the holding passes intact to the principal heir, and other heirs can obtain only limited shares in the form of annuities.

By 1908 the funds at the disposal of this Commission had been raised to 550,000,000 marks. In purchasing land compulsory expropriation is authorised when the land cannot be obtained otherwise. The land is not handed over to the peasants in its rough state, but drainage or irrigation works are previously undertaken. Roads are made and great care is taken to fix the area of the holdings with regard to their productivity, and to give each holding a good assortment of various qualities of soil without scattering the fields. En- 


\section{APPENDIX II}

deavour is made to place the homesteads sufficiently far apart to give each homestead plenty of elbow room, and to situate it with reference to its land so as to effect economy of time and labour, but not so far apart as to check the development of the collective spirit or of co-operative action.

In Southern Germany where the holdings are already small and fragmented, as noted above, the method by which the Commissions proceed is mainly restripment, i.e. the readjustment of fragmented holdings into compact and conveniently situated blocks. The following examples of this work may be given :-

"The land of Hohenhaida in Saxony consisted of 1374 acres belonging to 35 proprietors. It consisted of 774 separate plots. Restripment reduced the number of plots to 60 , most of which were served by a single central road. The work was executed at a cost of 3126 francs (Rs.1953), i.e. at a cost of (about) $2 \frac{1}{2}$ francs (Rs.1-9-0) per acre. By the saving of area occupied by roads and fences 21 acres were gained, that is to say, more than the cost of the operation. In consequence of the restripment it has been necessary to increase the size of the barns to provide for the larger outturn of the farms."

In another * case from Ostheim in Hanau it is stated :-

"After first rising in revolt against the proposed readjustment of their holdings, stoning the surveyors and chasing them away, the people of this commune ended by submitting to the proposal, and having seen the advantages which resulted, showed their appreciation in the way that they received the Minister for Agriculture. The Minister was received by almost all the male population on the outskirts of the village, and the chief of the deputation, who four years before had lodged the protest in Berlin, advanced and thanked the Minister for the readjustment of lands which had been carried out against the wishes of the

* Bulletin issued by the Ministry of Agriculture in 1884 and quoted on pp. 35355 of MI. Jouzier's "Economie Rurale". 


\section{SUBDIVISION IN OTHER COUNTRIES}

inhabitants, stating that they had not understood the matter, but now they quite appreciated the advantages of the operation which had in many cases trebled the value of the land affected."

In the above cases restripment was carried out under tine law upon the application of a majority of the land-holders affected.

Some* of the most recent legislation for preserving economic holdings intact has been passed in Schwartzburg Sondarshausen. A law of 1888 required the previous consent of the Provincial Governor before estates could be subdivided; but this was found to be inadequate. A "New Law against subdivision of land" passed in 1912 enacts that this consent to subdivision shall be given only on three conditions :-

(a) Payment of a fixed tax.

(b) Right of retrocession.

(c) Right of pre-emption for the Commune and Rural Bank.

The object of this law is to prevent subdivisions of land which are anti-economic and disastrous to the good working of farms.

D. Switzerland.-In Sivitzerland subdivision and fragmentation has been carried to such lengths that in one canton (Ticino) the average size of a farm is only 9 acres and the average number of separate parcels in each farm is 35 , the average area of each parcel being $\frac{1}{4}$ of an acre. When legislation was first introduced for restriping (i.e. readjustment of scattered holdings) the opposition on the part of the land-holders was great. The necessity for overcoming evils caused by this minute subdivision and for improving means of communication was so great, lowever, that the

* "Bulletin of the Bureau of Social and Economic Intelligence " for October, 1912, p. 203, published by the International Institute of Agriculture, Rome. 
legislation was forced through, and the results obtained were so satisfactory that the new provisions of the Swiss Civil Code, fixing once for all the principle of the necessity for the minority to conform to the decision of the majority, was well received by all parties concerned; and it is now held in Switzerland that the economic future of the country depends chiefly on the manner in which these provisions are applied in different cantons. The large number of small farms is negarded as a benefit, and all that the legislation aims at checking is a too minute subdivision which seriously checks production and land improrement. The earliest legislation took place in the canton of Lucerne in 1808 and in 1837 to encourage the union of small holdings; but these laws remained a dead letter because no provision was made for overcoming the opposition on the part of the minority.

The first law introducing the element of compulsion was passed in Ticino in 1852. This law granted to a proprietor the right of compelling his neighbour's to sell to him or to exchange plots of less than 300 square metres adjacent to his own property. The neighbouring proprietor might require in exchange a plot superior by one-fifth to the value of the plot given up by him. This law also remained inoperative. The law under which progress has been made is the law of 1902 for "the restriping and readjustment of landed property". This law lays down that as soon as the undertaking is planned the consent of a majority of proprietors concerned, or, in default of this, of a number of proprietors who represent half the land to be restriped, will be sufficient to compel the opposition to associate in the work. Restriping: may eren be ordered officially by the Council of State in the case of any commune or region of 10 hectares, when the average extent of the parcels in such commune or zone is less than 500 square metres. In 1908 restriping was declared to be compulsory by the Council of State in six communes.

Other cantons have passed very similar laws, and in 


\section{SUBDIVISION IN OTHER COUNTRIES}

many cantons restriping has been systematically ordered on a compulsory basis in connection with the construction of public works such as road-making, canals, drainage or surveys. Commissions are appointed to carry out the work and grants of public money made to facilitate the work. In the canton of St. Gall it is shown that restriping with eloser grouping, adapted to local conditions, has caused all the inconveniences due to subdivision and fragmentation to disappear, and the enhanced value of the holdings resulting: from this work is estimated at from 60 per cent. to 77 per cent.

As a result of the experience gained by the operation of these communal laws the principle has now been accepted in the Swiss Federal Legislation, and Article 703 of the Swiss Civil Code provides for the compulsory restriping of land when the project is approved of by two-thirds of the persons interested, representing more than half the land. The cantons have the power of modifying this provision for their own purposes, and work on their own laws. M. Girsberger estimates the increased value obtained by restriping at francs 500 per hectare (Rs.153 per acre), and calculates the minimum annual saving due to the work already undertaken at one million francs * (= Rs.6 $\frac{1}{4}$ lakhs).

E. Austria.-In Austria extensive agricultural work connected with the reform of land tenures, the reclamation of waste lands, homestead settlements, etc., is undertaken by Commissions. The restriping of fragmented holdings is part of the work entrusted to such Commissions. Under the law of 1883 restriping could be enforced upon the application of half the land-holders affected, but under a recent law restriping can be enforced upon the application of one-third of the land-holders affected, provided that they enjoy half the net yield of the parcels of land to be restriped.

* "Bulletin of Economic and Social Intelligence” for March, 1913, published by the International Institute of Agriculture, Rome. 
Much work of this nature has been accomplished, and it is recorded that "wherever" restriping has been carried out it has realised the results expected from it, increased the yield of the land and reduced the cost of production ".*

F. Spain.-The work + undertaken by the Gorernment with a view to the economic regeneration of farms in Spain falls under three heads :-

1. Splitting up big estates.

2. Uniting scattered parcels into economic holdings.

3. Bringing waste and unreclaimed land under cultivation.

Expropriation is permitted in the case of splitting up big holdings, and also in the case of restriping when it is necessary for the sake of providing each farm with an area sufficient for economical farming.

Specially aided Co-operative Institutions are brought into existence to aid these colonies of homestead farms.

G. Denmark.-In Denmark there is in each Department a Commission for the creation of small economic holdings. Between 1909 and 1914 the State has advanced sums amounting to the equivalent of Rs. $1_{4}^{\frac{3}{4}}$ crores for this purpose. The economic holdings so created cannot be subdivided nor united with other land. $\ddagger$

$H$. Sweden.-In Sweden the work of reconstituting peasants' farms was commenced a century ago. The objects of the operations were-

(a) To create compact holdings out of scattered lots.

(b) To enlarge farms which were too small to an area that would admit of economical farming.

The first law was passed in 1807 , and an amended law

* "Bulletin of Economic and Social Intelligence" for April, 1912, and May, 1913, published by the International Institute of Agricalture, Rome.

+ Tbid., December, 1912.

$\ddagger$ Ibid., March, 1912. 


\section{SUBDIVISION IN OTHER COUNTRIES}

passed in 1821 is the law still in force under which the work is done. This work has gone on very steadily for a century and some 260,000 farms have been reconstituted on this basis, and whereas the number of plots of land constituting a peasant's holding was formerly often from 20 to 40 , the average number is now only 2 . Of the total number of 260,000 farms mentioned 180,000 of the holders continue to live in the villages, and the other 80,000 holders, with their families, nearly a third part of the peasant land-holders of Sweden, have in the past century quitted the village site to go and live on their lands now united into larger lots.*

I. Itcly.-In Italy the Law of Inheritance allows a landowner to leave half his property as he likes, but the other half must be divided equally amongst his children. Owing to this law holdings have become much subdivided.

In 1894 an Act was passed which enabled a land-holder having land, the net income from which was calculated at between 200 and 600 francs per annum, to constitute this land as a "family property". A farm so constituted ceased to be the property of an individual and was held jointly by the family. It also became inalienable and could not be seized for debt.

In 1910 a further Bill was introduced to facilitate the creation of small farms of from $2 \frac{1}{3}$ to 7 acres each, to form which peasants could obtain from the Government loans on easy terms. The farms so formed were to remain indivisible. $\uparrow$

J. Russia.-The case of Russia is instructive because prior to 1906 a large part of the land was held jointly by families on a system somewhat analogous to the Hindu joint family

* "Bulletin of Economic aud Social Iutelligence" for OctoberNovember, 1910, published by the International Institute of Agriculture, Rome.

+ "Bulletin of Economic and Social Intelligence" for February, 1911; June, 1915; July, 1915, and February, 1917, published by the International Institute of Agriculture, Rome. 
system. With a view to improve the extremely backward and ineffective system of farming in Russia and to raise the peasants from their abject state of poverty, important agrarian legislation was undertaken in 1906. The two most important factors in the reforms instituted consisted of-

(a) The abolition of collective family ownership, and the substitution of the head of the family as the free and independent owner of the holding.

(b) The reuniting in one contiguous holding the scattered plots which formerly made up the holding.

These measures were applied in the case of some lands on the application of the holders, and in the case of others compulsorily.

It was objected that it was unjust to deprive the other members of the family of their rights in the holdings, and the theoretical "injustice" of the proceeding was admitted; but it was held that these men who were dispossessed of their illusory rights to a share of the produce of uneconomic holdings would be better off as free labourers, and that the measure was necessary for the regeneration of agricultural practice. As a matter of fact agricultural wages in Russia have risen largely since that time, and the condition of the dispossessed sharers has been improved.

As a result of these measures it is now reported that-

(a) More than three-fourths of the investigated farms have now land in one contiguous piece, while formerly the great majority consisted of six or more separate pieces of land, and many of them of 30, 40 or even 100 pieces.

(b) Most of the farmers now live on or near their own farm.

(c) More than 40 per cent. of the peasants have now carried out marked improvements on their farm lands.

(d) Agricultural implements have been greatly improved in quality.

(e) Agricultural practice has been greatly improved.

$(f)$ The harvest gathered in recent years on these newly 


\section{SUBDIVISION IN OTHER COUNTRIES}

settled farms is heavier than on farms still held on the old system.

K. Belgium.-In Belgium the Code Napoleon is in force and its operation has resulted in the creation of many small holdings, but in Flanders, at any rate, the holdings, though small, have not been seriously split up into separate parcels. This danger to a large extent was averted by the sagacity and care of the small land-owners. M. Emile de Lavalaye states:* "The Flemish peasant attaches too much value to the proper outline of a field to break it up into pieces; he would rather sell it altogether. He would never think of dividing the farm he cultivates amongst his children. On the contrary he will submit to extraordinary sacrifices to give the farm the size and typical shape it should have."

L. Holland.-In Holland there is an interesting tenure known as Beklem-reght which constitutes a permanent tenant right. This right can be sold, mortgaged or bequeathed, and is very similar to the Occupancy Right of the Bombay Presidency, but with this important difference that the right is indivisible and so presents an effective bar to injurious subdivision of land. In spite of this they are proposing in Holland to introduce legislation to facilitate restripment.

$\boldsymbol{M}$. Jersey.-In Jersey the Law of Inheritance is substantially the same as in France, but with this important difference that when a farm is of an area less than $1 \frac{1}{2}$ acre the eldest son inherits the whole.

N. Japan.-70 per cent. of the holdings in Japan are smaller than $2 \frac{1}{2}$ acres, and are much fragmented. The cultivated land of Japan is for the most part subdivided into small, narrow and irregular lots, with an insufficient and often unreasonable system of roads, and often imperfectly and not suitably irrigated and drained. With the object of increasing the produce of the soil, and preventing

* "Land System of Belgium and Holland," by M. Emile de Lavalaye (1880). 


\section{APPENDIX II}

the inconvenience caused by the existence of numerous small lots belonging to the same proprietor, and scattered over a large area, the Japanese Government, following the example of other countries, has appointed Commissions to effect readjustment of lands.

A law for the readjustment of lands was passed in 1899 and amended in 1909 . The law provides for-

1. The necessary interchange of land and the restriping of lots.

2. The construction of roads, irrigation works, etc.

In order to obtain authorisation to form a Syndicate for the readjustment of farm lands it is necessary to obtain the consent of at least half the land-owners in the tract in which the Syndicate intends to work, and these land-owners must represent two-thirds of the land affected. The farms restriped are exempted from land tax, and special credit institutions are provided to finance them.

So far as the work has gone, it has resulted in consicterable improvements in roads and canals, an increase in rice growing, and the general convenience of all concerned.*

* "Bulletin of Economic and Social Intelligence" for February, 1913, published by the International Institute of Agriculture, Rome, and "Outlines of Agriculture in Japan," pp. 22-3, issued by the Agricultural Bureau, Tokio (1910). 


\section{APPENDIX III.}

DRAFT BILL AND SHORT STATEMENT OF OBJECTS AND REASONS.

A Bill to Enable Land-owners in the Presidency of Bombay to Prevent the Excessive Subdivision of Agricultural Holdings.

Whereas it is expedient to enable land-owners in the Presidency of Bombay to prevent the excessive subdivision of agricultural holdings; and whereas the previous sanction of the Governor-General required by section 79, sub-section (2) of the Government of India Act, 1915, has been obtained for the passing of this Act; it is hereby enacted as follows :-

\section{Short Title and Extent.}

1. (1) This Act may be called the Bombay Economic Holdings Act, 191 .*

(2) It extends to the whole of the Presidency of Bombay except the city of Bombay and Aden.

\section{Definitions.}

2. In this Act unless there is anything repugnant in the subject or context-

(a) "collector" includes any person duly authorised to exercise the powers of a collector under this Act;

(b) "economic holding" means a plot of land registered for the time being as an economic holding under this Act;

* 5 and 6 Geo. V., c. 61. 
(c) "unoceupied land" means land which, by virtue of section 37 of the Bombay Land Revenue Code, 1879, or otherwise, vests absolutely in the Government, free from all encumbrances; *

(d) "instrument" means any document by which any right or liability is, or purports to be, created, transferred, limited, extended, extinguished or recorded ; $\dagger$

(e) "registered owner" means any person in whose name an economic holding is for the time being authorisedly registered; and

$(f)$ "prescribed" means prescribed by rules made under" this Act.

Kind of Land which may be Registered as an Economic Holding.

3. Any plot of agricultural land which, by reason of its size, situation, fertility, facilities for irrigation and other qualities, the collector may consider to be suitable for registration as an economic holding may be so registered, subject to the provisions of this Act and the rules for the time being in force thereunder.

\section{Application for Registration.}

4. (1) Except in the case of unoccupied land, no land shall be registered as an economic holding unless an application has been made in this behalf by some person interested in the land.

(2) On receipt of an application under sub-section (1), if the collector has reason to believe that the land to which the application relates is unsuitable for registration as an economic holding, or that all the persons interested in the land do not desire that it shall be so registered, or that there is any other sufficient ground for not proceeding further in the matter, he shall not be bound to cause notice to be given as hereinafter provided.

* Bombay V. of 1879. $+C f$. II. of 1899 , s. $2(14)$. 


\section{DRAFT BILL AND SHORT STATEMENT}

(3) Where the land which it is proposed to register as an economic holding is vested in a female subject to Hindu law, and such female does not possess an absolute interest therein, a reversioner shall, for the purposes of this section and of sections $5,6,7,9$ and 12 , be deemed to have an interest in the land.

\section{Notice Before Registration.}

5. (1) Before registering any land, other than unoccupied land, as an economic holding, the collector shall cause public notice to be given, stating that it is proposed to register such land as an economic holding.**

(2) Such notice shall be published on or near the land and at such other places and in such manner as may be prescribed.

(3) Such notice shall contain a description of the land sufficient to identify the same and shall contain such particulars as may be prescribed, and shall require all persons interested in the land to appear personally or by agent before the collector at a time and place mentioned (such time not-being earlier than fifteen days after the date of the publication of the notice) and to state the nature of their respective interests in the land and any objections which they may have to urge against the registration of the land as an economic holding.

(4) The collector shall also cause copies of such notice to be served on the occupier (if any) of the land and on all such persons known or believed to be interested therein or to be entitled to act for persons so interested, as reside or have agents authorised to receive service on their behalf in the district in which the land is situated. In case any person so interested lives elsewhere and has no such agent, the notice may be sent to him by post to his last known address.

\section{Requisitions for Information.}

6. The collector may also require any such person to make or deliver to him at a time and place mentioned (such time 
not being earlier than fifteen days after the date of the requisition) a statement containing, so far as may be practicable, the name of every other person possessing any interest in the land or in any part thereof and of the nature of such interest.*

\section{Inquiry and Registration.}

7. (1) On the day fixed under section 5 or on any other day to which the inquiry has been adjourned the collector shall inquire into the nature of the respective interests of the persons claiming to be interested in the land and the objections (if any) which any such person has to urge against the registration of the land as an economic holding. $\dagger$

(2) Where no person interested in the land who appears at the inquir'y raises any objection to its being registered as an economic holding, the collector may register the land accordingly in the prescribed register.

\section{Procedure for Inquiry.}

8. An inquiry under section 7 shall be conducted according to the procedure for formal inquiries as provided in the Bombay Land Revenue Code, 1879.

\section{Registration of Name of Owner.}

9. (1) In the case of land other than unoccupied land, the collector shall, at the time of registering an economic holding, enter it in the name of some person as registered owner.

(2) In the case of unoccupied land, the name of the registered owner may be entered at any time when the economic holding $\mathrm{Or}^{\circ}$ an interest therein is assigned by or on behalf of the Gorernment to any person.

(3) Only one person shall be entered as registered owner, and if the land is not unoccupied land and it is shown in the

$$
\begin{gathered}
{ }^{*} C f \text {. I. of } 1894, \text { s. } 10 . \quad+C f . \text { I. of } 1894, \text { s. } 11 . \\
+ \text { Bombay V. of } 1879 . \\
16
\end{gathered}
$$




\section{DRAFT BILL AND SHORT STATEMENT}

inquiry under section 7 that more persons than one possess an interest in it, the collector shall not register the land unless all the persons possessing an interest therein agree to its being registered in the name of one person.

\section{Economic Holding to Vest Absolutely in Registered Owner.}

10. The economic holding shall vest absolutely, free from all encumbrances, in the first registered owner from the date of the entry of such owner's name in the register; provided that nothing in this section shall be deemed to affect the provisions of the Bombay Land Revenue Code, 1879, or any conditions lawfully annexed, by the Gorernment or any Government officer, to the tenure of the land.*

Entry in Register to be Conclusive Proof.

11. (1) An entry in the prescribed register of any land as an economic holding, or a certified copy of such entry, shall be conclusive proof that such land is an economic holding.

(2) Where the name of the first registered owner has been entered in such register, the entry or a certified copy thereof shall be conclusive proof that the holding vested absolutely, free from all encumbrances, in such owner at the date of the entry, subject to the proviso to section 10 .

(3) The rule enacted by section 4 of the Indian Evidence Act, 1872, with respect to facts declared by the said Act to be conclusive proof, shall apply to the entries and copies referred to in sub-sections (1) and (2) of this section, in the same manner as if this section were a part of the said Act.t

\section{Cancellation of Registration.}

12. (1) The registered owner of an economic holding may apply to the collector for the cancellation of the registration of such holding.

(2) On receipt of such application the collector, if he is of 
opinion, after hearing the registered owner, that there are sufficient grounds for holding an inquiry, shall cause notice to be given that it is proposed to cancel the registration.

(3) Such notice shall contain a description of the economic holding sufficient to identify the same and shall require all persons who may have any objections to urge against the cancellation of the registration to appear personally or by agent before the collector at a time and place mentioned (such time not being earlier than fifteen days after the date of the publication of the notice) and to state their objections.

(4) Such notice shall be published on or near the land and at such other places and in such manner as may be prescribed.

(5) On the day fixed or on any other day to which the inquiry has been adjourned the collector shall inquire into any objections urged by any person present and may, subject to such rules as may be made under this Act, cancel the registration or not as he deems fit.

(6) The cancellation of the registration of an economic holding shall not affect any interest in the holding which any person possesses at the time when the registration is cancelled.

\section{Maintenance of Register.}

13. The collector shall maintain the prescribed register and shall from time to time enter therein the name of the person for the time being entitled to each economic holding registered therein, in such manner and according to such procedure as may be prescribed.

\section{Econonic Holdings are Impartible.}

14. An economic holding and every interest therein shall, notwithstanding any law or custom to the contrary, be deemed to be impartible and shall not be liable to subdivision. 


\section{DRAFT BILL AND SHORT STATEMENT}

Economic Holdings to be Held in Severalty.

15. (1) An economic holding shall be held absolutely and in severalty by the person entitled to it for the time being.

(2) This section is subject to the proviso to section 10 .

\section{ILLUSTRATIONS.}

(a) $A$, who is a member of a Hindu coparcenary, acquires an economic holding; such holding cannot in any circumstances become coparcenary property.

(b) Where a female succeeds to an economic holding, she takes an absolute interest in it.

Partition, Partial Transfer and Transfer to two or more Persons Prohibited.

16. (1) Every instrument and every agreement which purports, or which if carried into effect would operate-

(a) to effect any partition of an economic holding or of an interest therein, or

(b) to transfer or dispose of a part only of such holding or of an interest in such part, or

(c) to transfer an economic holding or a part thereof, or an interest in an economic holding or in a part thereof, to or for the benefit of two or more persons whether jointly, severally or in common,

shall, to that extent, and save as provided in sub-section (2), be void.

(2) Nothing in this section shall apply to a lease of part of an economic holding for a term not exceeding one year: provided that any instrument or agreement whereby the lessor agrees to renew the lease or in any manner to lease part of the holding for any further period, shall be void.

\section{ILLUSTRATIONS.}

(a) A sale or devise of one part of an economic holding to one person and of another part to another, or a mortgage 
effected on, or a life-interest created in, a part only of an economic holding would be unlawful.

(b) A trust under which the whole of an economic holding was rested in one trustee for the benefit of one beneficiary, would be lawful, but a trust which would rest the beneficial interest in several parts of the land in two or more persons would be unlawful.

(c) An economic holding cannot become the property of a firm of partners.

Cultivation and Occupation of Economic Holding by two or more Persons, or of a Purt only of an Economic Holding, Prohibited.

17. Every instrument and every agreement purporting to provide-

(a) for the cultivation or occupation of an economic holding by two or more persons, or

(b) for the cultivation or occupation by any person of any part only of an economic holding, shall be void whether such instrument or agreement purports to affect any interest in the land or not.

\section{Law of Succession.}

18. On the death intestate of the person entitled to an economic holding, the heir of such person shall, for the purpose of succession to such holding, be determined in accordance with the rules contained in the schedule.

Power of Collector to send Certificate to Court.

19. (1) Where it appears to the collector that by virtue of or in execution of a decree or order of any court in British India any part only of an economic holding or any interest in -such holding has passed or may pass into the possession of any person in contravention of the provisions of this Act, the collector may send a certificate under his 


\section{DRAFT BILL AND SHORT STATEMENT}

hand and seal to the court stating that the property to which the decree or order relates is an economic holding or a part thereof or an interest therein, or otherwise as the case may be, and showing in what manner the provisions of this Act have been contravened.*

(2) On receipt of such certificate the court shall remove any attachment or other process then pending against the said property, and shall set aside any sale or order for the sale or transfer thereof and shall cancel the said decree or order so far as it relates to the said property.

(3) In this section the expression "order of any court" includes the order of a person exercising powers under the control of a court, such as a receiver in insolvency jurisdiction.

(4) Nothing in this section shall be deemed to empower the collector to send such certificate in any case where the integrity of the economic holding is not and is not likely to be affected by the decree or order referred to in subsection (1).

\section{Eviction.}

20. The collector may summarily evict any person wrongfully in possession of any part of an economic holding.

$$
\text { Appeal, etc. }
$$

21. Any order passed by the collector under this Act shall be subject to such appeal or revision as is allowed by the Bombay Land Revenue Code, 1879, with respect to order's passed by revenue officer's. $t$

\section{Rules.}

22. (1) The Governor in Council may make rules to carry out the purposes of this Act.

(2) The power to make rules under this section is subject to the condition of the rules being made after previous publication.

${ }^{*} C f$. Bombay III. of 1874 , s. 10.

+ Bombay V. of 1879. 


\section{Saving of Powers of the Government for the Recovery of Revenue.}

23. Nothing in this Act shall affect any powers conferred on the Government, by any law for the time being in force, for the recovery of land revenue or of any sum recoverable as an arrear of land revenue.

\section{The Schedule.}

Rules of Succession to an Economic Holding.

(See section 18.)

1. The succession is traced from the person last entitled to the holding.

2. The succession is in the first place to the issue lineally of the person last entitled to the holding, the male issue being preferred to the female.

3. Where there are two or more heirs in equal degree, the eldest only succeeds.

4. The lineal descendants of any person deceased represent their ancestor, that is to say, they occupy the same position as he would have occupied if he had been alive.

5. On-failure of lineal descendants, the nearest lineal ancestor succeeds.

6. A paternal ancestor and his descendants are preferred to a maternal ancestor; a male paternal or maternal ancestor with his descendants is preferred to a female paternal or maternal ancestor respectively.

7. Illegitimate relationship is not recognised.

8. A person related by the half blood is capable of being the heir and stands in the order of succession next after any relation in the same degree of the whole blood and his issue where the common ancestor is a male, and next after the common ancestor where the common ancestor is a female.

9. Adoption is recognised whenerer it would be recognised under the law of succession to which the parties are subject in cases not governed by this Act. 


\section{DRAFT BILL AND SHORT STATEMENT}

\section{Statement of Objects and Reasons.}

1. It has long been a subject of comment in India that the land-holdings of cultivators have become subdivided up to a point at which they are now, in many localities, very small, and that the holdings, whether large or small, are frequently "fragmented" in a manner which is very prejudicial to effective cultivation. This progressive process of subdivision and fragmentation is due to the increase of population and to the fact that the laws of inheritance which are in force in this country operate in such a way as to give to each male member of a land-holder's family a share in the family land.

2. The same causes have produced precisely the same results in other countries, though in hardly any other country has the process been pushed so far. In many other countries legislation has been undertaken to remedy this state of affairs and has been found to be effective, resulting in an increase in the outturn of agricultural produce and a decrease in the cost of production. Such legislation has come to be recognised, even in countries where at first it met with much opposition, as altogether favourable to economic progress and to the production of increased wealth. The lines on which legislation has usually proceeded have been the compulsory and voluntary consolidation of holdings coupled with the provision that holdings once consolidated may not afterwards be subdivided.

3. In the Bombay Presidency in general, and in particular in the Konkan, West Deccan and the garden and rice tracts of Gujarat, subdivision and fragmentation of land have reached an intolerable point. Over large tracts the average size of the holding is only two or three acres, while fields measuring less than half an acre are found to be subdivided into more than twenty separately owned plots, many of them of less than one guntha ( $\frac{1}{40}$ th of an acre) apiece. The process of subdivision and fragmentation is continuously going on, both in tracts where the situation is already acute and in 
tracts where the holdings are still, on the whole, of reasonable dimensions.

4. The evils of this excessive subdivision and fragmentation of land may be briefly stated as follows:-

(a) they impede current cultivation and waste time;

(b) they prevent permanent improvements being undertaken;

(c) they prevent a cultivator from living on his farm;

(d) they prevent the organisation of labour and capital;

(e) they frequently result in second crops not being grown ;

$(f)$ they sometimes send the land out of cultivation altogether;

$(g)$ they cause enmity amongst neighbours, leading to litigation and permanent feuds;

(h) they produce a generally uneconomic situation.

In view of the fact that a large proportion of the cultivable land has been reduced to these unfarourable conditions, it is almost impossible to expect any substantial economic improvement amongst the majority of the land-holders until the fundamental impediment is removed. So long as the existing laws of inheritance continue to operate in such a way as to subdivide holdings continuously from generation to generation it is impossible either for land-owner's or for the Executive Government to take any steps in the direction of consolidation of holdings which would have more than a temporary effect. The object of this Bill is to enable such land-owners as may wish to do so to check the further subdivision of their lands and to enable them, when it is otherwise possible, to effect a permanent consolidation of their holdings; and also to enable the Executive Government to secure the same results in respect of unoccupied land. The legislation proposed is purely enabling, and it will be operative in the case of any holding only upon the expressed wish of every person possessing an interest in that holding. 


\section{DRAFT BILL AND SHORT STATEMENT}

5. The scheme embodied in this Bill for securing these objects is briefly as follows: In order to be constituted an economic holding a plot of land must be entered as such in a register prescribed by rules. If the land is occupied, it will rest with some person having an interest in the land to make an application to the collector to have the land registered as an economic holding. " Interest" is here used in the legal sense. $C f$. the use of the word in section $58(a)$ of the Transfer of Property Act, 1882.) Unless the collector consider's that there are sufficient grounds for rejecting the application, he holds a careful inquiry, in which he follows. a procedure similar to that prescribed in the Land Acquisition Act, 1894. If the proceedings show that all persons interested agree, the land is registered. Land vesting absolutely in Government may be registered without inquiry. The holding must in any case be registered in one name only, and the act of registration annuls all the interests of all other persons, except the registered owner, in the holding. Thereafter the owner cannot divide the plot, but must, so long as he owns it, keep it entire. He may sell, mortgage or otherwise dispose of it as an entire unit, but may not dispose of part of it or do anything that might result in splitting up the holding. On the death of the holder, if he has not disposed of the land by will, it will devolve upon a single heir. If the provisions of the Bill are contravened (for instance, if the holder mortgages a part of his holding and the mortgagee obtains a decree of possession), the collector is empowered to send a certificate to the court, and the court will set aside its decree or order. The collector may also evict the person in wrongful possession. When a plot has once been constituted an economic holding, the registration cannot be cancelled except with the consent of the collector: the grounds on which cancellation will be allowed will be laid down by rule, and it is proposed that it shall be permitted chiefly in cases where economic considerations indicate that it is expedient. 
6. There is some difficulty in framing provisions to secure the integrity of the holding in spite of existing law and custom in favour of the subdivision of land. As will be seen, the above scheme aims at effecting the object in view by giving the registered owner an exclusive interest in the holding at the outset; by preventing the subdivision of the holding by transfer inter vivos or by will or by the operation of law; and by preventing subdivision in the case of the owner's death intestate. Each of these provisions appears essential to the success of the Bill. With regard to the first, it may be said that wherever two or more persons are interested (whether jointly or otherwise) in a holding there is a probability that at some time the holders will desire to divide the land. The necessity for the second provision seems obrious; but it may be observed that in order to prevent partition the holding must not be permitted to become joint property or coparcenary property according to Hindu law. With regard to the third, there is considerable difficulty. If the operation of any law under which property is divided on an intestate succession is excluded, some rule of succession to take its place must be derised. Hindu and Mohammedan law, the Indian Succession Act, 1865, and the Parsi Intestate Succession Act, 1865, all contemplate the division of immoveable property on succession. The Hindu law, indeed, recognises impartible property, but the principles governing the succession to such property do not appear to be sufficiently clear for application to agricultural holdings, in connection with which it is desirable to prevent litigation as far as possible. Moreover as an economic holding could be transferred to any person, a law of succession that will prevent its subdivision in all cases, whatever the law of succession to which the transferee is subject, is required. The difficulty cannot apparently be surmounted except by enacting special rules of succession for economic holdings. Some provisional rules for this purpose have been set out in the schedule, but 


\section{DRAFT BILL AND SHORT STATEMENT}

they are intended merely as an example of what is indicated, for it is felt that the matter is one which can more satisfactorily be dealt with later, when those classes of the community who will be affected have had an opportunity of expressing their opinions on the Bill.

7. Those points in the Bill which require further explanation are noted below.

\section{Notes on Clauses.}

Clause 11.-Unless the title of the first registered owner can be readily proved, it is anticipated that adverse claims made after registration will give rise to litigation and cause difficulty.

Clause 12.-The Bill aims at the permanent prevention of excessive subdivision and it is therefore essential, when once a plot of land has, with the full assent of the persons affected (if any), been registered, to prevent the holder or his successors from procuring the cancellation of the registration without sufficient reason.

Clause 15, Illustration (b). - This appears to follow from the principles for succession adopted provisionally in the schedule. Males will be preferred to females and females will not succeed except in cases where they would almost necessarily take an absolute interest.

Clause 16. - It is hoped that the wording is not obscure. It is necessary to provide for dealings with "interest" as well as for dealings with the land, for it is probable that attempts to evade the section would be made in that way: the illustrations give some examples.

Clause 17.-Separate occupation or cultivation by two or more persons would be contrary to the purpose of an economic holding.

Clause 20.-This clause has been inserted to save the holder or the collector from the delay and expense of litigation in upholding the provisions of the Bill. The clause does 


\section{APPENDIX III}

not apply where a person has wrongfully obtained possession of the entire holding, as that is a contingency which is not from the economic point of view very material. The clause applies only in cases of subdivision.

The Schedule.-These rules have been taken from the English law relating to the descent of real property (vide Halsbury's "Laws of England," vol. 11). It is immaterial for economic purposes what rule of succession is adopted, provided that it ensures that the holding shall descend in its entirety, and the rules in the schedule are inserted merely as an example. 


THIS BOOK IS DUE ON THE LAST DATE STAMPED BELOW

\section{AN INITIAL FINE OF 25 CENTS}

WILL BE ASSESSED FOR FAILURE TO RETURN THIS BOOK ON THE DATE DUE. THE PENALTY WILL INCREASE TO 50 CENTS ON THE FOURTH DAY ANDD TO \$1.00 ON THE SEVENTH DAY OVERDUE.

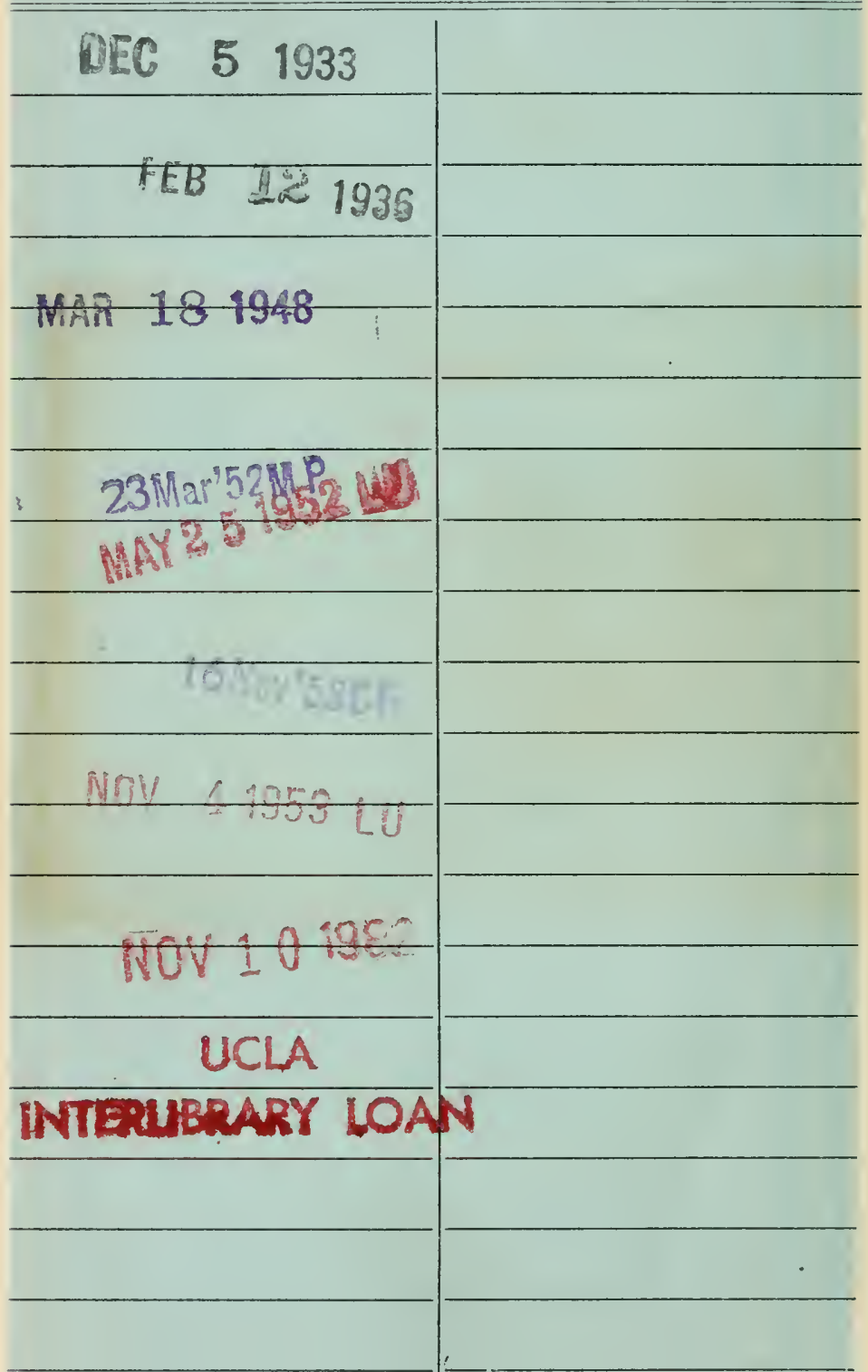


YE 57252.

476215

JNIVERSITY OF CALIFORNIA LIBRARY 
